\author{
UNIVERSIDADE DE SÃO PAULO \\ FACULDADE DE FILOSOFIA, LETRAS E CIÊNCIAS HUMANAS \\ DEPARTAMENTO DE GEOGRAFIA
}

PROGRAMA DE PÓS-GRADUAÇÃO EM GEOGRAFIA FÍSICA

Hélio Garcia Paes

"CONTRIBUIÇÕES DA GEOGRAFIA AO LICENCIAMENTO E AO ESTUDO DE IMPACTO AMBIENTAL"

São Paulo

2010 


\author{
UNIVERSIDADE DE SÃO PAULO \\ FACULDADE DE FILOSOFIA, LETRAS E CIÊNCIAS HUMANAS \\ DEPARTAMENTO DE GEOGRAFIA
}

PROGRAMA DE PÓS-GRADUAÇÃO EM GEOGRAFIA FÍSICA

\title{
“CONTRIBUIÇÕES DA GEOGRAFIA AO LICENCIAMENTO E AO ESTUDO DE IMPACTO AMBIENTAL"
}

\author{
Hélio Garcia Paes
}

Dissertação apresentada ao Departamento de Geografia da Faculdade de Filosofia, Letras e Ciências Humanas da Universidade de São Paulo para obtenção de titulo de Mestre em Geografia.

Orientador: Profo. Dro ${ }^{\circ}$ Luis Antonio Bittar Venturi

São Paulo

2010 
Hélio Garcia Paes

Contribuições da Geografia ao Licenciamento e ao Estudo de Impacto Ambiental

Dissertação apresentada ao Departamento de Geografia da Faculdade de Filosofia, Letras e Ciências Humanas da Universidade de São Paulo para obtenção de titulo de Mestre.

Área de Concentração: Geografia Física

Aprovado em: 120

Banca Examinadora:

Prof.(a) Dr.(a) Instituição: Assinatura:

Prof.(a) Dr.(a) Instituição: Assinatura:

Prof.(a) Dr.(a) Instituição: Assinatura: 


\section{AGRADECIMENTOS}

Ao Professor Luis Bittar pela valiosa orientação, sem a qual, o projeto apresentado não redundaria nesta dissertação; bem como em sua compreensão em entender meus prazos e cronogramas;

Ao Professor Wagner Costa Ribeiro pelas sugestões apresentadas na banca de qualificação, que ajudaram a enriquecer este trabalho e a dar um melhor direcionamento nos objetivos do mesmo;

À Professora Fernanda Padovesi pelas sugestões apresentadas na banca de qualificação, que contribuíram na melhora deste trabalho;

A todos os professores da Geografia (graduação e pós-graduação), por quem tenho grande admiração e respeito;

À Ana Cláudia Covacic pelo companheirismo, compreensão e ajuda de sempre;

Ao Juliano pela ajuda de sempre;

Aos amigos e colegas que contribuíram de alguma forma, para o andamento deste trabalho: Ana, Gisele, Juliano, Fabrícia, Tatiana, Alan, Everaldo, Magda, Roberta, Nádia, Kelly, Eduardo, Cícero, Paulo e Caio.

À minha família: Hélio, Maria e Juvenal (in memorian). Néia, Sybelle, Chrystianne, Victor, Yara, Natan, Bueno, Ramos, Adilson, Toco;

E a todos os amigos e colegas, que direta ou indiretamente contribuíram para que eu atingisse meus objetivos acadêmicos, profissionais e pessoais. 


\section{RESUMO}

Este trabalho tem o objetivo principal de demonstrar o potencial de atuação dos geógrafos na elaboração de Estudos de Impacto Ambiental (EIAs), a partir da formação multidisciplinar deste profissional, alcançada pelo seu preparo teóricometodológico, técnico, sua formação científica e sua postura crítica, as quais embasam sua participação em diferentes relatórios contidos dentro dos EIAs, bem como na coordenação dos mesmos, ou na produção de mapas que acompanham os diagnósticos. São também demonstrados exemplos práticos dos relatórios passíveis de serem executados pelos geógrafos, além de ter sido realizado um levantamento quantitativo e qualitativo da participação deste profissional neste ramo de atividade, por meio da análise de quarenta EIAs, inseridos no período de 2000 a 2009, tendo como espacialização, o Estado de São Paulo. Assim, objetivou-se também, que este trabalho pudesse servir de subsídio para quem pretende ingressar nesta carreira, indicando caminhos e demonstrando a diversidade de contribuições a serem oferecidas pelos geógrafos.

Palavras-chave: Geografia, geógrafo, licenciamento ambiental, diagnóstico ambiental, impacto ambiental, meio ambiente. 


\begin{abstract}
The aim of this work is to indicate the potential participation of geographers in Environmental Impact Assessments (EIAs), based on the multidisciplinary formation of this professional, achieved by their theoretical-methodological, technical, scientific background and critical stance, which gives support to their participation in various reports contained within the EIA, as well as its coordination, and production of maps that accompany the diagnosis. This work also demonstrates practical examples of reports that can be carried out by geographers, and a quantitative and qualitative survey about the participation of professionals in this field, supported by the analysis of forty EIAs, in the period 2000 to 2009, having the State of Sao Paulo as spatial basis. Therefore, this work also aims to subsidy those willing to join this career, indicating ways and demonstrating the diversity of contributions to be offered by geographers.
\end{abstract}

Key words: geography, geographer, environmental licensing, environmental impact, environmental assessment, environment. 


\section{LISTA DE FIGURAS}

Figura 3.2-1: Ocupação dos trabalhadores do município de São Paulo, percentual por setores de atividade. Fonte: PMSP, 2004 .76

Figura 3.5-1: Precipitação Média no Município de São Paulo, período de "Normais

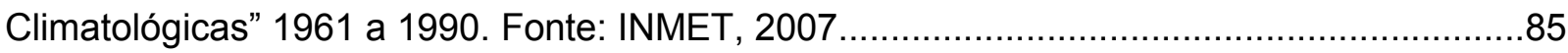

Figura 3.6-1: CO - Máximas (8 horas) - RMSP e Interior - 2006. Fonte: CETESB, 2006.......89

Figuras 3.9-1 e 2: A esquerda, vista parcial da Lamina d'água ocorrente na propriedade e a direita, vista de um furo de sondagem a trado manual executado na área, evidenciando o fluxo de água no interior do banco de areia existente.

Figura 3.11-1: Exemplo de delimitação de área de estudo sobre a foto aérea 103

Figuras 4.1-1 a 4: Em sentido horário, a partir de cima, a esquerda: cava de mineração a ser recuperada, após a análise do PRAD, pelos órgãos ambientais competentes. Outra cava de mineração. Bacia de rejeitos da atividade mineira. E por último, área de antiga cava já recuperada e com o plantio de algumas mudas nativas. 112

Figura 4.2-1: Vista parcial do terreno, objeto de estudo, onde será implantado o aterro sanitário, trata-se de um local bem escolhido, uma vez que a conformação em fundo de vale, permite um maior aproveitamento para esta atividade. 116

Figuras 4.3-1 a 4: Em sentido horário, a partir de cima, a esquerda: área em processo de licenciamento. Curso d'água natural, receptor de esgotos e drenagem de chuvas. Exemplo de residência de alto padrão localizada próximo a área do empreendimento. Residências autoconstruídas e barracos existentes a cerca de $1 \mathrm{~km}$ da área de alto padrão 119

Figura 4.4-1: A direita da fotografia, terra e entulho depositados irregularmente na propriedade, alvo de advertência da polícia ambiental. 


\section{LISTA DE MAPAS}

Mapa 3.1-1: Exemplo de um Mapa de Uso e Ocupação do Solo elaborado para um trabalho realizado por este autor. 71

Mapa 3.3-1: Sistema viário regional, exemplo de um mapa constante num licenciamento de área localizada no litoral paulista, após a descrição e compreensão do sistema viário regional, ilustra-se com o mapa, como forma de se visualizar as informações elencadas. .79

Mapa 3.10-1: Mapa de caracterização de vegetação elaborado para um trabalho realizado por este autor. 99

Mapa 3.11-2: Exemplo de mapa de localização elaborado para o estudo de impacto ambiental, mesma área da foto aérea anteriormente apresentada. 


\section{LISTA DE TABELAS}

Tabela 3.2-1: Densidade Demográfica Município de São Paulo, 1950-2000. Fonte: PMSP, 2004

Tabela 3.4-1: Um dos dados constantes em relatório sobre resíduos sólidos: valores de coeficiente per capita de produção de resíduos sólidos domiciliares, em função da população urbana. Fonte: CETESB, 2.007.

Tabela 5-1: Principais efeitos e aspectos ambientais induzidos por um empreendimento de mineração. Fonte: Sánchez, 2008, p. 203 (adaptado). 125

Tabela 6.1-1: Estudos de Impacto Ambiental (pequeno e médio portes: PRAD, EAS e RAP's).

Tabela 6.1-2: Estudos de Impacto Ambiental (grande porte: EIA-RIMA's) 131

Tabela 6.1-3: Resumo do Número de profissionais que mais participaram dos EIAs 133

Tabela 6.1-4: Quadro de Técnicos do DAIA, em Janeiro de 2009, época do levantamento das informações. 135 


\section{LISTA DE SIGLAS}

ADA. .Área Diretamente Afetada

AGB Associação dos Geógrafos Brasileiros

AID Área de Influência Direta All. Área de Influência Indireta APP Área de Preservação Permanente ART Anotação de Responsabilidade Técnica CETESB Companhia Ambiental do Estado de São Paulo CONAMA Conselho Nacional do Meio Ambiente CREA. Conselho Regional de Engenharia e Arquitetura DAIA. ..Departamento de Avaliação de Impacto Ambiental DEPRN. ..Departamento Estadual de Proteção aos Recursos Naturais DG. Departamento de Geografia DUSM. Departamento de Uso do Solo Metropolitano EAS. Estudo Ambiental Simplificado EIA. Estudo de Impacto Ambiental EIA-RIMA ....................Estudo de Impacto Ambiental e Relatório de Impacto ao Meio Ambiente EIV-RIVI.....................Estudo de Impacto de Vizinhança e Relatório de Impacto de Vizinhança FFLCH. .Faculdade de Filosofia, Letras e Ciências Humanas IBAMA. Instituto Brasileiro de Meio Ambiente e dos Recursos Naturais Renováveis IF. Instituto Florestal LUOS Lei de Uso e Ocupação do Solo MEC Ministério da Educação PCNs. Planos Curriculares Nacionais RAP. Relatório Ambiental Preliminar

RCA-PCA Relatório de Controle Ambiental e Plano de Controle Ambiental SMA. Secretaria Estadual do Meio Ambiente USP Universidade de São Paulo 


\section{ÍNDICE GERAL}

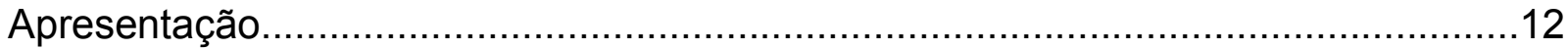

1. Introdução

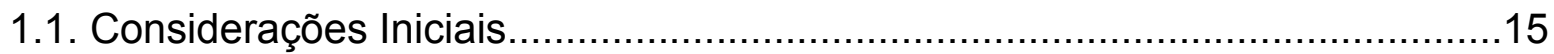

1.2. A Importância do Licenciamento e dos Estudos de Impacto Ambiental

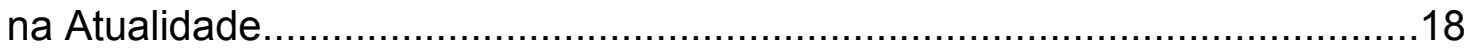

1.3. Licenciamento Ambiental no Estado de São Paulo........................................20

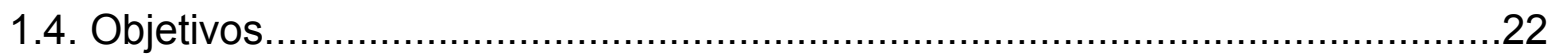

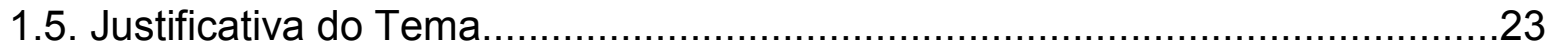

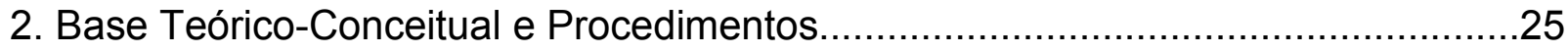

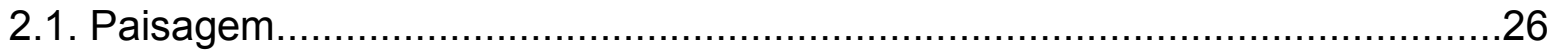

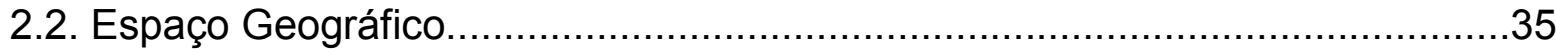

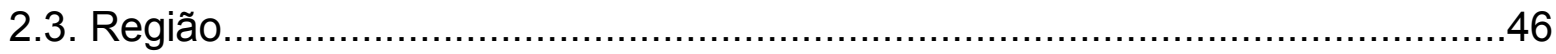

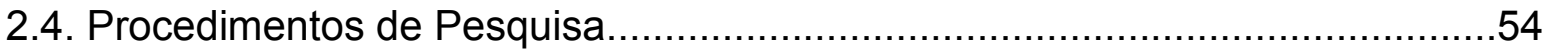

2.5. Atribuições Profissionais Legais do Geógrafo.............................................55

2.6. Geografia, Geógrafos e os Estudos de Impacto Ambiental...........................56

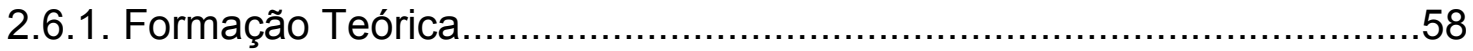

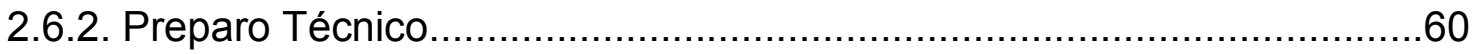

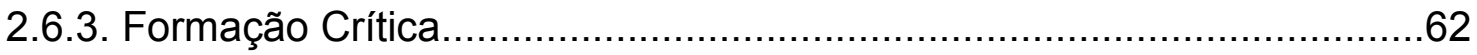

3. Relatórios Passíveis de Serem Elaborados pelo Geógrafo..................................67

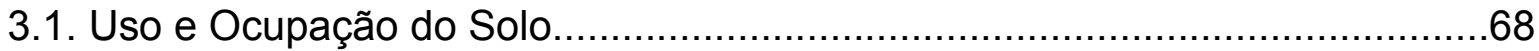

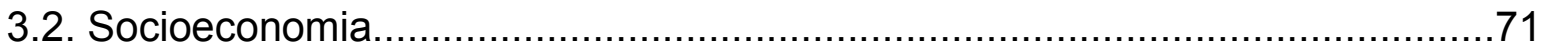

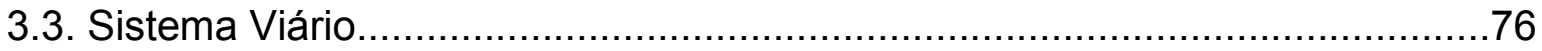

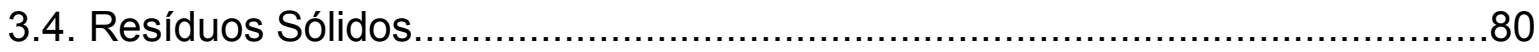

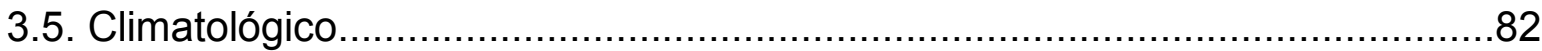

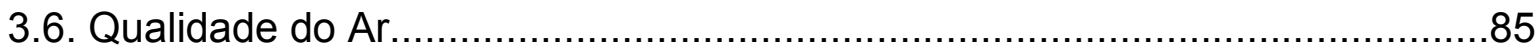

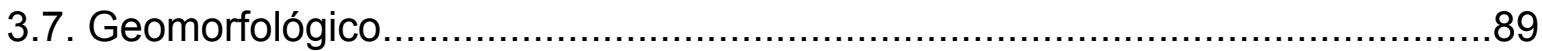

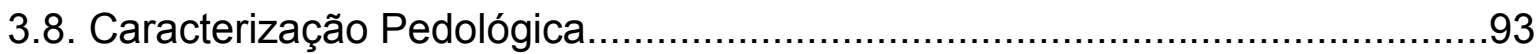

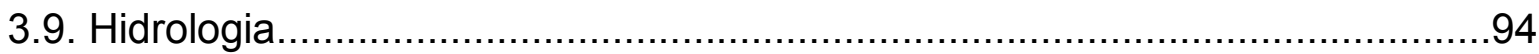

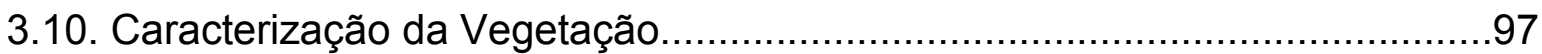

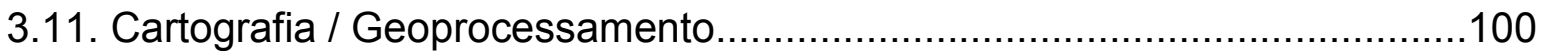

3.12. Coordenação de Estudos de Impacto Ambiental....................................104

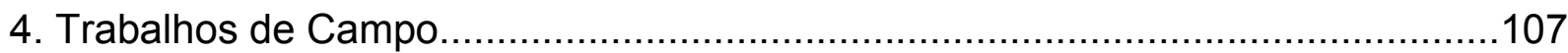

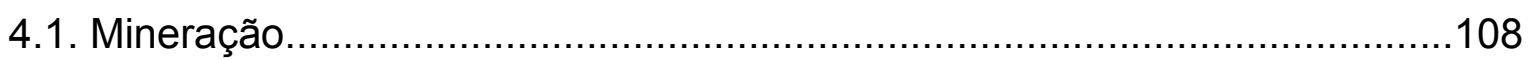




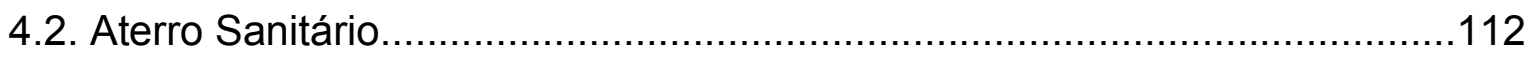

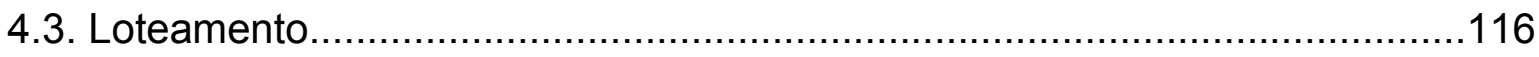

4.4. Regularização Ambiental de Propriedade ................................................119

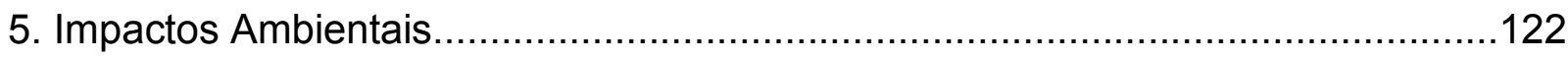

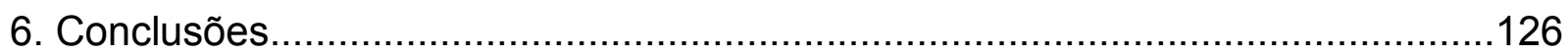

6.1. Conclusões Qualitativas e Quantitativas................................................129

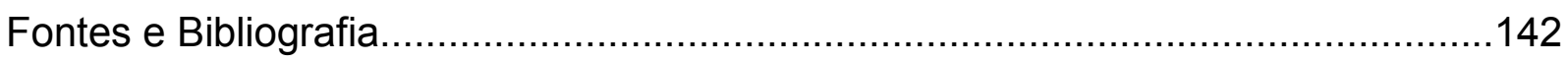

Anexo A - Questionário 01: Para profissionais com formações diversas..................147

Anexo B - Questionário 02: Para geógrafos.....................................................148 


\section{APRESENTAÇÃO}

O tema desta dissertação, antes mesmo que eu percebesse, surgiu no ano de 2003, quando tive o primeiro contato com o licenciamento ambiental, ao começar a trabalhar na Secretaria Estadual do Meio Ambiente (SMA), ainda com pouco preparo técnico e científico de geógrafo, uma vez que cursava o $3^{\circ}$ ano da graduação.

No andar do prédio em que eu trabalhava, havia cerca de 20 (vinte) técnicos diferentes de formações variadas, dos quais, 03 eram geógrafos. $O$ departamento em que atuei era supervisionado por um engenheiro agrônomo e dirigido por um engenheiro florestal, os quais não simpatizavam com profissionais da Geografia, alegando terem tido problemas com estes, em sua passagem por lá. Para eles os geógrafos, se mostravam desinteressados, dispersos ou despreparados, e queriam entender de áreas que não deveriam, principalmente vegetação, na qual os dois eram especialistas. Motivos que os fizeram deduzir, que os geógrafos, não eram qualificados para atuarem naquele departamento.

Assim, havia certa discriminação contra geógrafos, por parte dos dois profissionais que comandavam o departamento e a mim diretamente, fazendo com que eu me esforçasse o máximo para desfazer este preconceito. Após 02 anos neste lugar, saí com reconhecidos méritos por parte destas pessoas, que talvez tenham mudado seus pensamentos, ao menos em parte.

Não obstante, no meu próximo emprego, em uma consultoria ambiental privada, que realizava os Estudos de Impacto Ambiental (EIAs), a serem submetidos à aprovação dos órgãos competentes, eu era dirigido por uma geógrafa, a qual trabalhava mais diretamente com as negociações do que com a elaboração dos EIAs e por um geólogo. Nos primeiros meses em que eu trabalhei ali, ela foi convidada a expor para uma platéia de estudantes de Geografia, as possibilidades de atuação do geógrafo na área de licenciamento ambiental e acabou me perguntando o que este profissional poderia elaborar dentro dos EIAs.

Este fato me fez pensar que, se nem os geógrafos sabem quais estudos eles podem elaborar dentro dos EIAs, não podemos exigir que o "mercado" o saiba. Portanto, há 
a necessidade de divulgação de nossas atribuições legais, técnicas, teóricometodológicas, científicas e críticas nesta área de atuação.

Nesses mais de 06 anos, tenho trabalhado na elaboração de EIAs, tendo participado de mais de 50 projetos diferentes; alguns estudos pontuais, realizados em uma semana, para identificação de vegetação, por exemplo; outros, de grande porte, com tempo de realização total de até 06 meses, como para o licenciamento de grandes loteamentos residenciais, mineração, linhas de transmissão de energia, aterros sanitários, complexos de lazer, instalações industriais, instalações portuárias, condomínios residenciais, ente outros.

Os estudos de grande porte, é bom que se diga, são elaborados por diversos profissionais e em alguns casos, havia equipes formadas por 10, 20, 30 técnicos ou mais. Na divisão de tarefas, cada um escolheria o estudo para elaborar, o mais próximo de sua formação, experiência profissional, ou aptidão pessoal. Esta divisão permitiu que eu realizasse estudos do meio antrópico - uso e ocupação do solo, socioeconomia, sistema viário, resíduos sólidos; do meio físico - hidrologia, climatologia e qualidade do ar e do meio biótico - vegetação, além de coordenar alguns trabalhos.

Permaneci por quase dois anos nesta consultoria privada, depois trabalhei de forma autônoma, na elaboração dos mesmos estudos acima citados, por mais de dois anos; na sequência atuei na supervisão ambiental de obras rodoviárias no Estado de São Paulo e, atualmente, na mesma atividade, porém em obras ferroviárias.

Esta minha experiência profissional redundou, evidentemente, na escolha do tema desta dissertação, acreditando que com ela, eu possa contribuir para os estudantes ou os bacharéis de Geografia conhecerem com exatidão, sua área de atuação e que eles se valorizem, perante outros profissionais, reconhecendo que sua contribuição, nesta área profissional é a maior que uma ciência sozinha pode oferecer dentro dos estudos de impacto ambiental. Nos próximos itens pretende-se que isto fique mais evidente. 


\section{INTRODUÇÃO}

Esta dissertação de mestrado foi estruturada em seis capítulos principais e seus sub-capítulos. No primeiro, buscou-se apresentar o tema Licenciamento Ambiental, sua importância para a Geografia e para a sociedade como um todo, demonstrando como se dá a inserção dos atores envolvidos nesta atividade e o papel que o geógrafo pode exercer neste ramo profissional. Apresentaram-se ainda os objetivos do trabalho e a justificativa do tema para a Geografia.

No segundo capítulo são expostos: a base teórico-conceitual e os procedimentos de pesquisa que irão permear o trabalho até o seu final, além das atribuições legais do geógrafo, amparadas na lei que disciplina a profissão, bem como, nos aspectos intrínsecos a sua formação, sob seus aspectos teórico, técnico e crítico, os quais ofertam a este profissional, uma atuação bastante diferenciada, quando comparada a outros.

O capítulo três apresenta os relatórios, comumente contidos nos Estudos de Impacto Ambiental, de médio ou grande porte (RAP ou EIA/RIMA, por exemplo) passíveis de serem elaborados pelos geógrafos, sempre amparados pela base teórico-conceitual demonstrada anteriormente.

No quarto capítulo são demonstrados trabalhos de campo realizados por este autor, para a elaboração de quatro diferentes tipos de relatórios, para quatro empreendimentos distintos, de forma a ilustrar na prática, a participação de um geógrafo nestes referidos estudos.

$\mathrm{Na}$ sequência, capítulo cinco, é apresentada uma breve descrição de impactos ambientais, definição e conceito, bem como, uma tabela-exemplo de alguns impactos previstos a partir da implantação de um empreendimento minerário.

O sexto capítulo traz as conclusões obtidas após a pesquisa empreendida, alicerçadas na base teórico-conceitual e nos objetivos preconizados, bem como amparada em questionários respondidos por profissionais atuantes neste ramo e na quantificação da participação de diversos profissionais atuantes nos EIAs em detrimento da participação do geógrafo. 


\subsection{Considerações Iniciais}

O licenciamento ambiental da mais variada gama de empreendimentos no Estado de São Paulo é precedido de estudos de impacto ambiental, realizados por profissionais com formações diversificadas, os quais buscam atender às necessidades específicas de cada licença.

Os estudos de impacto ambiental, por sua vez, são elaborados a partir da obtenção de "dados e informações técnico-científicas", bem como pelo "tratamento dado a este material" (Bastos; Almeida, 2002, p. 106), de forma a atender as legislações federal, estadual e municipal em vigência e são produzidos de acordo com a nova atividade a ser empreendida.

(...) estudos ambientais são exigíveis para obter-se uma autorização governamental para realizar atividades que utilizem recursos ambientais ou tenham o potencial de causar degradação ambiental. Tal autorização, conhecida como licença ambiental, é um dos instrumentos mais importantes da política ambiental pública. (Sánchez, 2008, p. 80)

Há uma grande diversidade de estudos de impacto ambiental a serem apresentados aos órgãos de licenciamento para a obtenção das licenças necessárias à implantação de um novo empreendimento, para os quais a contribuição da Geografia e do cientista e profissional geógrafo revestem-se de grande importância.

Dependendo do tipo de empreendimento a ser licenciado, faz-se necessária a elaboração de um EAS - Estudo Ambiental Simplificado, o qual pode ser considerado um trabalho de pequena magnitude; para empreendimentos com impactos mais relevantes, exige-se a apresentação de um RAP - Relatório Ambiental Preliminar, podendo ser considerado um estudo de média magnitude; já para empreendimentos mais impactantes, faz-se necessária a apresentação de um EIA-RIMA - Estudo de Impacto Ambiental e o respectivo Relatório de Impacto ao Meio Ambiente.

Esses estudos de impacto ambiental exigidos pela Secretaria Estadual do Meio Ambiente, CETESB - Companhia Ambiental do Estado de São Paulo e também por algumas secretarias municipais, ou na instância federal, pelo IBAMA - Instituto Brasileiro de Meio Ambiente e dos Recursos Naturais Renováveis, para o 
licenciamento de atividades potencialmente causadoras de impacto ao meio ambiente, são elaborados por equipes multidisciplinares e, em alguns casos, com a ausência de um profissional da Geografia.

Os conselhos profissionais determinam o campo de atuação de diversos profissionais que compõem a equipe de trabalho responsável pela elaboração de um estudo de impacto ambiental. Neste sentido, muitas das atribuições pertinentes ao geógrafo são também passíveis de serem executadas por outros profissionais.

Mas por que, então, há escassez de geógrafos na realização dessas atividades e o predomínio de outros profissionais, muitas vezes pouco qualificados para tarefas com uma grande possibilidade de realização pelos formados em Geografia?

No estado de São Paulo, o antigo DAIA ${ }^{1}$ - Departamento de Avaliação de Impacto Ambiental, inserido na Secretaria do Meio Ambiente foi incorporado pela CETESB e a Diretoria de Tecnologia, Qualidade e Avaliação Ambiental é a nova responsável pela análise da maioria desses estudos. Nesta diretoria, de acordo com o tipo de empreendimento, há uma "distribuição" para os departamentos que os analisarão para a verificação da viabilidade técnica de implantação do empreendimento a que se refira o presente estudo.

Desta forma, a Diretoria de Tecnologia, Qualidade e Avaliação Ambiental da CETESB, analisa grande parte do trabalho, repassando, quando necessário, a outros departamentos dentro ou fora da SMA - Secretaria do Meio Ambiente, para a verificação pertinente às suas competências técnicas e legais.

Assim, de forma simplificada, seguem em resumo, a atribuição de cada departamento envolvido na análise dos estudos de impacto ambiental:

\footnotetext{
${ }^{1}$ A configuração dos departamentos da Secretaria de Meio Ambiente do Estado de São Paulo sofreu modificações radicais em sua estrutura, a partir da Lei estadual $n^{\circ} 13.542$, de 8 de maio de 2009, que confere novas atribuições à CETESB, implantando uma nova estrutura no licenciamento ambiental, na qual a CETESB irá englobar as funções exercidas por antigos departamentos, como o DAIA, DEPRN e DUSM. Muitos profissionais que eram contratados por fundações, como a FIA e FUNDUNESP já foram e estão sendo desligados do quadro de funcionários e sendo substituídos por pessoas, sobretudo, oriundas de concursos (CETESB e SMA). Contudo, os EIAs, acredita-se, continuarão sendo os mesmos, quanto a forma de elaboração e de avaliação, mas poderão, possivelmente, exigir mais de um ou outro relatório contido nos mesmos.
} 
O antigo DEPRN - Departamento Estadual de Proteção aos Recursos Naturais, que incorporado pela CETESB, denomina-se atualmente: Diretoria de Licenciamento e Gestão Ambiental irá analisar os aspectos ligados à Vegetação e Áreas de Preservação Permanente ligadas a cursos d'água, nascentes, topos de morro e declividades.

O antigo DUSM - Departamento de Uso do Solo Metropolitano, agora também denominado Diretoria de Licenciamento e Gestão Ambiental, só se manifesta quando o empreendimento está localizado em Áreas de Proteção aos Mananciais da Região Metropolitana de São Paulo, ligados à Represa Guarapiranga e Billings, por exemplo.

A CETESB - antiga Companhia de Tecnologia de Saneamento Ambiental, agora Companhia Ambiental do Estado de São Paulo irá responder por quase todos os aspectos do licenciamento ambiental, repassando somente em casos específicos a conselhos gestores ou prefeituras, por exemplo.

Os Conselhos Gestores se manifestam quando o empreendimento estudado está inserido em alguma área de proteção ambiental, tal como a APA - Área de Proteção Ambiental do rio Tietê, por exemplo.

Já o IF - Instituto Florestal, é responsável pela destinação do valor de 0,5\% enviado pelo empreendedor ${ }^{2}$ a uma unidade de conservação, como forma de compensação ambiental, pelo impacto causado pelo novo empreendimento a ser instalado.

Dentro desses departamentos e dessas diretorias são encontrados alguns problemas para a análise dos estudos de impacto ambiental, por parte dos técnicos que ali trabalham, entre os quais estão a falta de estrutura, a formação, algumas vezes, em áreas díspares àquelas relacionadas ao meio ambiente e à burocracia que em muitas circunstâncias emperra a análise.

Não obstante, a análise por parte dos órgãos ambientais esbarra, algumas vezes, em construções ideológicas ou pessoais (ordens hierárquicas), do que deve ou não

\footnotetext{
${ }^{2}$ Este percentual de $0,5 \%$ está por ser modificado, visto que já está em discussão, uma nova maneira de quantificá-lo, sem a fixação exata para todos os empreendimentos, portanto, o mesmo, poderá ser variável.
} 
ser aprovado no âmbito da Secretaria do Meio Ambiente. Espera-se que com a incorporação do DAIA pela CETESB, os critérios técnicos sejam priorizados. Muitos técnicos que trabalharam no DAIA, afirmaram ter que dar prioridade na análise de determinados EIAs de empreendimentos em detrimento de outros que já aguardavam há muito mais tempo para serem avaliados; ou EIAs que apresentavam um déficit grande de informações e que tiveram que ser aprovados, mesmo sem apresentarem dados essenciais para a avaliação de impactos, entre outras situações.

No geral, a aprovação dos estudos de impacto ambiental são, em sua maioria, concretizadas; o que varia muito é o prazo dessa aprovação, que muda de acordo com as complementações exigidas pelos órgãos supracitados e pela disponibilidade de técnicos para a análise. Muitas vezes, um único profissional, seja ele com qualquer formação acadêmica é que, sozinho ${ }^{3}$, irá analisar o estudo de impacto ambiental, no departamento responsável por determinada análise de parte do estudo, seja pelo grande número de processos acumulados, seja por não haver um quadro técnico multidisciplinar em sua seção.

\subsection{A Importância do Licenciamento e dos Estudos de Impacto Ambiental na Atualidade}

Quando a microeconomia de grandes empresas comanda a macroeconomia de um país, obtendo vantagens financeiras, infra-estrutura, normatizações, facilidades, o comportamento privado aparece como o comportamento da nação. Para permanecer em um país, estas exigem uma gama de adoções políticas e administrativas, muitas vezes apoiadas por discursos ideológicos de desenvolvimento e ancoradas no marketing de incremento para a região que

\footnotetext{
${ }^{3}$ Com a nova estrutura da CETESB está se implantando outra forma de avaliação dos EIAs (a qual ainda não está totalmente implementada), separando-se os mesmos em três grandes aspectos: Físicos, Biológicos e Socioeconômicos e, dependendo da formação do profissional envolvido na análise, ele irá se incumbir de verificar, em cada estudo, os capítulos pertencentes a um destes temas. Mas há rumores também, de que isto possa não ocorrer, devido ao quadro de funcionários técnicos existente e as dificuldades iniciais apresentadas com esta estrutura.
} 
receberá investimentos, fazendo com que pressões político-populares facilitem a sua implementação e a consequente viabilidade operacional, apoiada em doação de terrenos e isenções de impostos por um determinado período de tempo, entre outros benefícios.

Assim, muitos empreendimentos têm sua aprovação exigida pela população, com a promessa de geração de empregos, ou de melhoria da qualidade de vida local, mesmo que para isso o impacto ambiental seja de proporções relevantes e que seu retorno à população não seja aquele esperado por ela e "prometido" no estudo.

O professor Antônio Carlos Robert de Moraes destaca que:

A miséria é grande obstáculo para o planejamento, seja por imprimir caráter emergencial em qualquer ação e por subordinar qualquer outra prioridade, seja ainda por aparecer ante o plano (quando não são respondidas suas demandas próprias), como "variável aleatória" que subverte as metas buscadas. E responder a demandas historicamente acumuladas, como no caso do Brasil, requer grandes aportes de investimentos, logo, uma grande determinação política.

Compatibilizar os imperativos do crescimento econômico, posto pela situação social reinante, com um padrão sustentável de utilização dos recursos naturais e ambientais é o desafio posto para o planejamento brasileiro. O desenvolvimento sustentável é o nosso enigma: decifra-me ou devoro-te. Crescer sem poluir e sem destruir o patrimônio natural do país emerge como a meta alicerçada no objetivo geral de melhorar a qualidade de vida e o bem-estar da população. (Moraes, 1999)

Os estudos de impacto ambiental cumprem o papel, primeiro de adaptar o empreendimento a ser licenciado à legislação brasileira e, segundo, o de minimizar o impacto causado pela implantação do mesmo, seja através da escolha das melhores áreas para as edificações, preservando áreas impróprias ou de proteção ambiental, seja pelo oferecimento de medidas mitigadoras e/ou compensatórias apresentadas pela equipe que o produziu, algo que não ocorreria sem o trabalho da equipe multidisciplinar. Ou ainda, pelo próprio marketing utilizado por muitas empresas que procuram se beneficiar do enquadramento de seu empreendimento na legislação ambiental, como se não fosse uma obrigação fazê-lo e sim uma benfeitoria promovida por ela.

O debate sobre ônus e benefícios de projetos de desenvolvimento é atualmente mediado pela avaliação de impacto ambiental, que passou a desempenhar um papel de instrumento de negociação entre atores sociais. 
(...) A aprovação do projeto implica certos compromissos assumidos pelo empreendedor, que são delineados no estudo de impacto ambiental, podendo ser modificados em virtude de negociações com os interessados. (Sánchez, 2008, p. 95)

O licenciamento ambiental pode contribuir para o crescimento econômico aliado ao desenvolvimento sustentável, graças às medidas mitigadoras e/ou compensatórias sugeridas nos estudos de impacto ambiental, as quais devem ser exigidas sua execução pelos órgãos licenciadores no momento da liberação das licenças cabíveis.

Assim,

"a preocupação dos planejadores, dos políticos e da sociedade como um todo deveria ultrapassar os limites dos meros interesses de desenvolvimento econômico e tecnológico, visando ao desenvolvimento que leve em conta não só as potencialidades dos recursos naturais, mas, sobretudo, as fragilidades dos ambientes naturais perante as diferentes inserções dos homens na natureza." (Ross, 2006, p. 52)

\subsection{Licenciamento Ambiental no Estado de São Paulo}

A constituição de leis que rege o licenciamento ambiental deve ser entendida como um processo histórico empreendido por diversos setores da sociedade brasileira, tendo o Estado de São Paulo como um de seus precursores, graças à luta de ativistas, ambientalistas e poder público na busca de soluções para a regulação das questões complexas relacionadas a este tema.

O licenciamento ambiental é um dos instrumentos da Política Nacional do Meio Ambiente, juntamente com a avaliação de impacto ambiental, com a fiscalização e monitoramento, elaboração de zoneamento ambiental ou ecológico-econômico e a criação de espaços protegidos (Unidades de Conservação, por exemplo).

Não obstante, o licenciamento ambiental refere-se às praticas utilizadas pelo poder público para a organização dos empreendimentos a serem implantados e/ou regularizados com vistas ao atendimento da legislação vigente nas diversas esferas, sejam elas municipais, estaduais ou federais, propiciando uma melhor ocupação do território no âmbito social, ambiental e econômico. 
A emissão de licenças, por parte da SMA, está condicionada à certidão de uso e ocupação do solo, emitida pela prefeitura municipal, pois, compete ao Município regular o uso e a ocupação do solo em seu território, através do Plano Diretor e em conformidade com as leis federais e estaduais pertinentes.

Mesmo que o plano diretor seja uma exigência, apenas para os municípios com mais de 20 mil habitantes, aqueles que não atinjam esta população, devem também regular o uso do solo em seu território, emitindo as certidões necessárias à instalação de novos empreendimentos em sua jurisdição, caso estejam de acordo com esta implantação.

Além das diretrizes municipais, em alguns casos, o empreendimento deve estar em concordância com diretrizes estaduais e federais, ainda no que se refere ao uso e ocupação do solo, como o Zoneamento Estadual (Ecológico-Econômico do Litoral Norte; ou Parques Estaduais, como o da Serra do Mar, por exemplo).

De acordo com a Secretaria Estadual do Meio Ambiente:

O Licenciamento Ambiental é um procedimento pelo qual o órgão ambiental competente permite a localização, instalação, ampliação e operação de empreendimentos e atividades utilizadoras de recursos ambientais, e que possam ser consideradas efetiva ou potencialmente poluidoras ou daquelas que, sob qualquer forma, possam causar degradação ambiental.

Enquanto instrumento de caráter preventivo, o Licenciamento é essencial para garantir a preservação da qualidade ambiental, conceito amplo que abrange aspectos que vão desde questões de saúde pública até, por exemplo, a preservação da biodiversidade, com o desenvolvimento econômico. Neste início de século, são cada vez mais importantes o debate e a busca por um desenvolvimento que coexista harmoniosamente com o meio ambiente - um desenvolvimento sustentável, que se baseia em três princípios básicos: eficiência econômica, eqüidade social e qualidade ambiental. Portanto, o Licenciamento atua numa perspectiva que pode contribuir para uma melhor qualidade de vida das gerações futuras. (SMA, 2007)

A preocupação com questões ambientais é crescente no Brasil. Frequentemente vêse a sociedade civil se posicionando perante o Poder Público, exigindo uma postura ambientalmente responsável, inclusive quanto à implementação de mecanismos coercitivos à degradação ambiental. A importância da preservação e da recuperação do meio ambiente tem motivado a elaboração de legislação específica sobre o 
assunto, bastante ampla, que denota grande preocupação com os impactos advindos de atividades potencialmente danosas ao meio ambiente.

Existe uma preocupação crescente em conciliar um desenvolvimento adequado com questões relacionadas à saúde pública, de tal forma a promover condições ambientais básicas que não agridam a comunidade e o local onde os empreendimentos serão instalados. Assim, os esforços feitos para promover a melhoria dos níveis de poluição, seja em termos do ar, água, solo, ruído, etc. tornam-se fundamentais. Os empreendedores, cada vez mais, devem ter consciência das necessidades locais e responder às suas prioridades e preocupações. (SMA, 2007)

A fim de avaliar corretamente os riscos embutidos no desenvolvimento dessas atividades, instituíram-se os estudos de impacto ambiental, em distintas esferas e aplicabilidades.

Assim, o Licenciamento Ambiental é uma ferramenta de fundamental importância, pois permite ao empreendedor identificar os efeitos ambientais do seu negócio, e de que forma esses efeitos podem ser gerenciados. A Política Nacional de Meio Ambiente, que foi instituída por meio da Lei Federal $n^{\circ}$ 6.938/81 estabeleceu mecanismos de preservação, melhoria e recuperação da qualidade do meio ambiente visando assegurar em nosso país o desenvolvimento socioeconômico e 0 respeito à dignidade humana. $O$ Licenciamento é um desses mecanismos; ele promove a interface entre o empreendedor, cuja atividade pode vir a interferir na estrutura do meio ambiente, e o Estado, que garante a conformidade com os objetivos dispostos na política estabelecida. (SMA, 2007)

\subsection{Objetivos}

Este trabalho tem como objetivo principal demonstrar o potencial de atuação dos geógrafos na elaboração de estudos de impacto ambiental, sistematizando as contribuições que a formação em Geografia proporciona aos seus cientistas, e ao enriquecimento dos estudos, quando elaborados por estes profissionais.

Com este trabalho, buscar-se-á demonstrar a importância da presença de geógrafo(s) na equipe multidisciplinar reunida para a elaboração do estudo de impacto ambiental oficial, sobretudo os realizados no Estado de São Paulo, ressaltando cinco aspectos de sua formação profissional: preparo teóricometodológico, técnico, sua formação científica e sua postura crítica, as quais embasam sua participação em diferentes capítulos dos estudos, bem como em sua 
capacidade coordenativa obtida com uma formação multidisciplinar própria do bacharelado em Geografia.

Serão demonstrados também, exemplos práticos, dos tipos de estudos passíveis de serem realizados pelos geógrafos.

Assim, os objetivos específicos desta dissertação são:

- Identificar as atividades pertinentes aos geógrafos junto ao CREA - Conselho Regional de Engenharia e Arquitetura;

- Realizar uma análise comparativa entre as competências legais (constantes na Lei $n^{\circ} 6.664$, de 26 de junho de 1979, a qual disciplina a profissão de geógrafo) e as que na prática são realizadas por estes profissionais;

- Analisar criticamente a perda de (ou o pouco) espaço na atuação no licenciamento e nos estudos de impacto ambiental por parte dos geógrafos para outros profissionais;

E como resultados esperados a partir da pesquisa empreendida:

- Apontar novos e antigos caminhos de atuação, a partir da comparação realizada entre as atribuições legais e as atividades que concretamente têm sido realizadas pelos geógrafos;

- E indicar, a partir da sistematização empreendida, as práticas e estudos relacionados ao licenciamento e aos estudos de impacto ambiental, para os quais, o profissional formado em Geografia, é capacitado a atuar.

\subsection{Justificativa do Tema}

Os estudos de impacto ambiental são elaborados por equipes técnicas multidisciplinares e muitos dos relatórios contidos dentro desses estudos têm sido elaborados por profissionais das mais variadas formações, como engenheiros, elaborando laudos de uso e ocupação do solo; geólogos elaborando laudos geomorfológicos, engenheiros, arquitetos e sociólogos escrevendo laudos sócio- 
econômicos; biólogos e engenheiros elaborando laudos climatológicos e de qualidade do ar, por exemplo.

Além desses relatórios, existem outros, os quais os geógrafos têm plena capacidade de executar, como os de Resíduos Sólidos, ou até de vegetação e que dificilmente os faz. Há ainda muitos profissionais elaborando mapas, habilitação curricular dos geógrafos.

O que derivou desta falta de atuação dos geógrafos foi um grande número de engenheiros, gestores ambientais, arquitetos, sociólogos, economistas, e tantos outros profissionais realizando tarefas que podem perfeitamente ser executadas pelos geógrafos. A questão aqui não é a atuação desses outros profissionais, mas a habilitação do geógrafo em executá-los e a pouca ocupação deste profissional nestes postos de trabalho.

Se, por um lado, é perfeitamente normal, na ausência de um geógrafo, que um engenheiro agrônomo, florestal ou biólogo faça um laudo de vegetação. Ou que um engenheiro faça um projeto específico, ou ainda que um geólogo elabore um laudo geológico ou pedológico, por outro lado é de se estranhar que laudos de clima, socioeconomia, geomorfologia ou uso e ocupação do solo, por exemplo, sejam elaborados por profissionais que não sejam qualificados por essas áreas de conhecimento e que esses relatórios sejam totalmente aceitos pelos órgãos responsáveis pela análise, sem qualquer tipo de questionamento.

Cabe a ressalva de que as respostas do CREA - Conselho Regional de Engenharia e Arquitetura, para os geógrafos são extremamente atribuladas, muitas vezes, por não haver alguém que defenda a categoria em tempo integral, apenas em consultas escritas e que podem demorar muito a ser respondidas.

“... o caráter corporativo que vigora no sistema" (CONFEA/CREA) "pode apresentar dificuldades para a atuação do geógrafo. Existe uma tradição em questionar as habilidades e competências de um profissional no sistema. Ela se baseia na formação de cada escola." (Ribeiro, 1999, p. 118)

Nesse contexto, o entendimento pretérito e presente das atribuições do geógrafo no campo técnico de atuação devem ser mais bem estudados para subsidiar o próprio CREA na tomada de decisões e na garantia de existência da profissão nesse 
conselho, uma vez que a perda de (ou o pouco) espaço dos geógrafos tem sido vista em todos os campos de atuação, até mesmo na área educacional, a qual não é objeto deste trabalho, mas sabe-se que tem sido disputada por economistas, historiadores, sociólogos, geólogos e demais profissionais.

Assim, a importância deste tema para a Geografia, por um lado, configura-se na própria conscientização de espaço de trabalho para o geógrafo neste campo profissional, em plena ascensão no Estado de São Paulo e no Brasil. A elaboração de estudos de impacto ambiental tem sido e continuará sendo uma área fértil de atuação para este profissional. Para isto, é necessário conhecer as particularidades de atuação, bem como as competências e fragilidades concernentes a esta categoria profissional.

Por outro lado, esta dissertação pretende servir de subsídio para quem pretenda ingressar nesta carreira de geógrafo, na construção ou análise de estudos de impacto ambiental, se não esgotando as possibilidades de atuação, pelo menos apontando caminhos e demonstrando a riqueza de contribuições a serem oferecidas por este profissional.

\section{BASE TEÓRICO-CONCEITUAL E PROCEDIMENTOS}

Para avaliar o potencial do geógrafo, sobretudo enquanto cientista, mas também enquanto técnico atuante no mercado de trabalho, neste caso na área de licenciamento ambiental, por meio da elaboração de estudos de impacto ao meio ambiente, dentre as principais categorias com as quais trabalha e que o embasam para tal atividade, encontram-se a Paisagem, Espaço e Região, as quais serão mais bem detalhadas na sequência.

Igualmente importante para esta dissertação, e especificamente no que se refere às atribuições profissionais legais do geógrafo, a análise será amparada nas leis que regulamentam a profissão, disponíveis junto ao CREA e também em publicação organizada pela $\mathrm{AGB}^{4}$.

\footnotetext{
${ }^{4}$ Associação dos Geógrafos Brasileiros: "Geógrafos - Legislação, Formação e Mercado de trabalho", organizado por Nelson Garcia Pedroso.
} 
Além da base teórica da formação do geógrafo e do amparo legal da sua profissão, serão discutidas também, questões relacionadas ao preparo técnico, formação científica e crítica do geógrafo, como forma de expor sua aptidão para a contribuição aos estudos de impacto ambiental, demonstrando com isso sua capacidade na elaboração de determinados relatórios constantes nos EIAs.

As informações acima são de certa forma, endossadas por Ross:

(...) a Geografia contemporânea encontra-se preparada, mais que outras ciências, para os estudos ambientais, pois dispõe dos métodos necessários, com imenso volume de dados e informações científicas sobre o meio natural e seus recursos, bem como sobre o grau e as formas de sua proteção e aproveitamento econômico. (Ross, 2006, p. 16)

\subsection{Paisagem}

O conceito de paisagem é de extrema relevância para esta dissertação, bem como para o geógrafo que trabalha na elaboração de estudos de impacto ambiental destinados ao licenciamento de atividades causadoras de modificação ao meio ambiente, pois é, na paisagem que se verificarão, sobremaneira, as modificações causadas pela implantação de um novo empreendimento.

Quase todos os empreendimentos passíveis de licenciamento ambiental causam a modificação da paisagem, em alguma escala, seja na paisagem marcada por sua vegetação nativa, por seus atributos geomorfológicos, seja naquela já com algum grau de antropismo. Raros são os empreendimentos que não modificarão a paisagem, restritos há alguns gasodutos ou oleodutos subsuperficiais, por exemplo, que por meio de técnicas construtivas conseguem não impactar a superfície abrangida pelo mesmo, embora, ainda assim, em alguns pequenos trechos seja necessária alguma intervenção.

A paisagem, até mesmo para o simples observador, em primeira instância, acaba por se constituir no raio do visível, onde o impacto pode ser apreendido por qualquer pessoa atingida pelo empreendimento alvo de estudo.

Ao se estudar o conceito de paisagem, na perspectiva sistêmica que predomina na Geografia física, confronta-se com a possibilidade de uma melhor compreensão dos estudos de impacto, causadores de modificações do meio, conceito este integrador 
dos aspectos físico, biótico e antrópico, que são alvo de relatórios dentro do EIA/RIMA, RAP, EAS, etc.

Assim, este conceito integrador será mais bem trabalhado na sequência, demonstrando-se sua importância para a Geografia e para o geógrafo que trabalha com estudos ambientais, com um apanhado do conceito utilizado por autores através dos tempos, bem como sua relevância na atualidade.

O termo paisagem, cotidianamente utilizado, surge inicialmente no "Livro dos Salmos, poemas líricos do antigo testamento, escritos por volta de 1.000a.C." A conotação inicial dada a esta palavra é, até os dias de hoje, de certa forma, a que a acompanha, pois referia-se neste texto "à bela vista que se tem do conjunto de Jerusalém, com os templos, castelos e palacetes do rei Salomão." (Metzger, 2001, p.02).

Contudo "foi apenas no século XIX, com os naturalistas alemães, que o termo paisagem adquiriu um significado científico e transformou-se em um conceito geográfico [Landschaft] derivando-se ainda em paisagem natural [Naturlandschaft] e paisagem cultural [Kulturlandschaft]". (Venturi, 2008)

O século XIX, marcadamente conhecido como o período de sistematização das ciências humanas e naturais, trouxe em seu bojo, a formação do positivismo que primava pela observação e descrição dos fenômenos, inventários sem a busca pontual da explicação. Neste contexto, o conceito de paisagem é inserido e acaba por acompanhar a tendência "científica" do período, sendo entendida como algo estático, que está ali para ser olhado e descrito, algo imutável. Nessa época, a paisagem era vista, sobretudo, como algo natural, descrita a partir de suas características físico-biológicas

O russo Dokuchaev, por exemplo, criador do conceito de complexos naturais territoriais, na última década do século XIX, vai caracterizar a paisagem a partir de porções de terra com características semelhantes e sua descrição, conformando-se num primeiro período da conceituação da paisagem.

Um segundo momento, pode ser caracterizado, a partir da teoria de evolução das espécies, de Charles Darwin, publicada em 1859, ainda no mesmo século XIX, que 
paralelamente, acaba por constituir um marco divisor das ciências naturais. Introduzindo a idéia de evolução, a partir de um ancestral comum, por meio de seleção natural, tornando-se a explicação científica dominante para a diversidade de espécies na natureza. Buscava-se, então, a gênese dos fenômenos.

Na década de 1920 é retomado o conceito de paisagem, agora com conotação cultural, ou paisagem transformada pelo homem, através do geógrafo Carl Sauer. Para ele, não se pode entender a natureza de uma área, até que se tenha aprendido a vê-la como uma unidade orgânica para compreender a terra e a vida em termos recíprocos. (Sauer, 1925)

Já na década de 1930, surge o conceito de ecologia da paisagem e de Teoria Geral dos Sistemas, empreendendo ao conceito de paisagem um dinamismo que não existia ainda, caracterizando-se então, como um terceiro momento, a análise integrada.

A análise sistêmica - cujo enfoque principal, está na inter-relação dos fenômenos, na ciclicidade dos mesmos, em sua transformação e deslocamento - trará uma compreensão diferenciada de análise da paisagem e da natureza, permitindo entender, por exemplo, como se dão alguns ciclos: da água, dos minerais, do ar, demonstrando, assim simplificadamente, que os elementos se transformam, se renovam, mudam de lugar, mas são sempre os mesmos.

Este tipo de análise, que surgiu na biologia, vai demonstrar que quando se interfere em um elemento constituinte da natureza, interfere-se também nos outros, seja no relevo, no solo, seja na vegetação, numa complexa relação de interdependência. Neste raciocínio, se os raios solares diminuíssem, haveria uma mudança radical do sistema terrestre, não permitindo a vida tal qual é conhecida hoje, uma demonstração de que há um imbricado de fatores que confluem para o funcionamento da vida na Terra e, por conseguinte, na própria constituição das paisagens.

As paisagens não são estáticas; passam por mudanças no tempo e no espaço, sejam elas naturais ou culturais; estão em permanente mutação e os materiais, embora mudem de lugar, de estado físico, não desaparecem. A natureza transforma- 
se, regida por processos dinâmicos, muitas vezes invisíveis ao homem, embora este possa acelerar essa transformação, tornando as paisagens culturais mais freneticamente mutáveis do que as naturais.

Nas palavras de Bertrand:

A paisagem não é a simples adição de elementos geográficos disparatados. É, numa determinada porção do espaço, o resultado da combinação dinâmica; portanto instável, de elementos físicos, biológicos e antrópicos que, reagindo dialeticamente uns sobre os outros, fazem da paisagem um conjunto único e indissociável, em perpétua evolução. (Bertrand, 1971, p. 02)

Bertrand (1971), baseando-se em escalas têmporo-espaciais propostas por Tricart e Cailleux (1965), estabelece uma hierarquização da paisagem em seis níveis de grandeza: Zona (mais de 10 milhões de km2, ligada ao conceito de zonalidade planetária), Domínio (1 a 10 milhões de km2), Região (10 mil a 1 milhão de km2), Geossistema (100 a 10.000 km2), Geofácie (de 1 a 100 km2) e Geótopo ( com menos de $1 \mathrm{~km} 2)$.

Esse autor, assim como Sotchawa, vai colocar na escala, a importância para se estudar a paisagem, vista como algo dinâmico. As escalas são inseparáveis dos estudos de paisagens; escalas diferentes vão apresentar resultados diferentes, escalas pequenas geram estudos genéricos; escalas maiores geram resultados mais detalhados. Acrescenta-se aqui a noção de escala temporal, permitindo entender a dinâmica e modificação da paisagem no tempo, por exemplo, tendo havido um período mais frio, há cerca de 12 mil anos, a conseqüência foi a redução de florestas, seguida de um período mais úmido, resultando em aumento das mesmas. Assim, para Bertrand, "os elementos constituintes de uma paisagem são mais ou menos sempre os mesmos; seu lugar respectivo e, sobretudo suas manifestações no seio das combinações geográficas dependem da escala têmporo-espacial". (1971). Ele acredita que a maneira mais fácil de designar uma paisagem é por sua vegetação, que para ele representaria a melhor síntese do meio.

Já Klink, refere-se freqüentemente ao termo "geocomplexos", o qual seria composto por fatores ecológicos ou geofatores, sendo eles: o solo e o substrato geológico, relevo, o balanço hídrico, a comunidade de seres vivos, vegetação e fauna, e o clima, este último considerado de extrema importância na análise. Para ele, o 
resultado das interconexões dos geofatores forma os sistemas interativos (ou ecossistemas) que compõem a paisagem. E "cada paisagem contém unidades espaciais (ou ecótopos) que são aproximadamente uniformes, bem com revelam seus balanços de energia de massa." (Klink, 1981, p. 05)

Ele afirma que a pesquisa geoecológica deve ter o conhecimento exato das interações no interior do ecossistema vida-ambiente, e daí surge à importância de se conhecer muito bem os geofatores. Para ele a geoecologia ou ecologia da paisagem se refere ao "estudo da massa natural e dos balanços de energia de uma paisagem." (Klink, 1981, p. 01)

Delpoux, por sua vez, exclama que o termo ecossistema, proposto por Tansley em 1935 é um vocábulo do ecologista e paisagem um termo geográfico. Com objetivo de "geografizar" a paisagem ele a designa como a "entidade espacial correspondente à soma de um tipo geomorfológico (suporte) e de uma cobertura no sentido mais amplo deste termo (da floresta à aglomeração e à zona industrial, passando pelas culturas ou superfícies aquáticas)", bem como a denomina como o "objeto concreto, materialmente palpável, diretamente perceptível no terreno. Certamente de estrutura complexa, diversificada, dinâmica". (Delpoux, 1974, p. 22) Em outras palavras, para ele a dimensão da paisagem está ligada ao critério de homogeneidade, portanto não se pode pré-estabelecer uma ordem de grandeza para a mesma.

Baseando-se na definição de ecossistema de Odum (1958), em que se considera a troca entre as partes animadas e inanimadas de um sistema para se produzir um sistema estável, ele propõe a caracterização de três tipos de paisagens: paisagens material e energicamente equilibradas, como sendo aquelas naturais, pouco marcadas pelo homem; paisagens exportadoras de energia e paisagens importadoras de energia, tendo como exemplos, uma área de cultivo e uma cidade, respectivamente.

Já Ab'Saber, trabalha com o conceito de domínio morfoclimático, como sendo "um certo espaço relevante em áreas continentais, onde através das ações dos climas, sobretudo os mais recentes, houve o "modelar" que reflete as atividades climáticas regionais" (2003), ou seja, é uma área onde o clima influi na morfologia regional 
associado com hidrologia e ações dos sistemas ecológicos ali existentes e a cobertura vegetal como produto desses processos.

Ab'Saber entende a paisagem como sendo sempre uma herança, "herança de processos fisiográficos e biológicos, e patrimônio coletivo dos povos que historicamente as herdaram como território de atuação de suas comunidades." (Ab'Saber, 2003, p. 09)

Com "Carlos Augusto de Figueiredo Monteiro, o termo paisagem adquire um significado mais amplo e o conceito torna-se uma categoria de análise para a pesquisa geográfica", possibilitando ao "geógrafo identificar diferentes unidades de paisagens segundo sua necessidade de pesquisa." (Venturi, 2008, 9. 51, 52.)

Para Carlos Augusto de Figueiredo Monteiro (1974), a paisagem

"é uma entidade espacial delimitada segundo um nível de resolução do geógrafo (pesquisador) a partir dos objetivos centrais da análise, de qualquer modo, sempre resultante da integração dinâmica, portanto instável, dos elementos de suporte e cobertura (físicos, biológicos e antrópicos) expressa em partes delimitáveis infinitamente, mas individualizadas através das relações entre elas que organizam um todo complexo (Sistema), verdadeiro conjunto solidário e único, em perpétua evolução." (Monteiro, 2000, p.39)

Este mesmo autor afirma que extrair um sistema na multiplicidade dos fenômenos da superfície terrestre é ato mental, que depende da formação intelectual e da percepção ambiental apresentada pelo pesquisador.

Assim, "os geógrafos dispõem de uma certa liberdade que lhes é extremamente necessária em virtude de uma característica inerente à Geografia, que se refere à grande diversidade temática que abrange, seja no âmbito social ou natural. (Venturi, 2008, p. 53)

Na Espanha, "Gómez Orea (1991) traz para o conceito de paisagem a relação sujeito-objeto ao propor que a paisagem reflete a bagagem cultural do sujeito que a percebe". Ele "destaca a reciprocidade na relação Homem-meio ao afirmar que o Homem cria a paisagem e, ao mesmo tempo, modela-se afetiva e fisicamente a ela. Esta concepção de Orea reflete sua forma de trabalhar com o planejamento do meio físico." (Venturi, 2008, p. 50) 
Com uma forma de abarcar a conceituação até aqui empreendida acerca do conceito de paisagem pode-se afirmar que:

A paisagem, e isso é comum às definições, é a resultante da interação entre seus componentes, a saber, clima, relevo, redes hidrográficas, solos, substrato geológico, cobertura vegetal [componentes físicos e bióticos regidos pelas forças físico-químicas que dinamizam a natureza], além do Homem que se impõe sobre a dinâmica natural conduzido por uma dinâmica social, permeada de valores histórico-culturais. Assim entendida, as partes do todo/paisagem já estão identificadas, cabendo ao Geógrafo, orientado pela análise, compreender sua dinâmica, seu funcionamento. E essa compreensão só será possível pela recomposição do todo como resultado, não da soma das partes, mas da relação entre elas. A síntese, portanto, completa o raciocínio analítico. Isso ocorre pois, embora os mecanismos mentais que conduzem à análise e à síntese possam ser considerados opostos [a análise fragmenta e a síntese recompõe], são processos complementares. (Venturi, 2008).

Assim,

A paisagem apresenta inúmeras possibilidades de dimensionamento, em função das diferentes perspectivas da análise. Isto ocorre porque, dependendo delas, os componentes da paisagem terão pesos diferentes no processo analítico. Uns poderão ser determinantes enquanto que outros poderão pouco influenciar em sua delimitação territorial.

Esses aspectos ou variáveis serão definidos pelas hipóteses elaboradas [no caso de haver questões a serem respondidas] ou pelas variáveis ou critérios eleitos para a análise.

Com tantas possibilidades de pesquisa, é absolutamente necessário que o Geógrafo liberte-se dos dimensionamentos preestabelecidos, das grades dimensionais, das ordens de grandeza e dos sistemas hierarquizados.

Não há paisagens pré-dimensionadas no mundo real; quem o faz é o sujeito pesquisador orientado por um objetivo de pesquisa e subsidiado por uma categoria de análise.

Assim, a paisagem geográfica só existe segundo um olhar humano, e cabe ao Geógrafo defini-la e compreendê-la apoiado no arcabouço teórico e conceitual que dispõe. Para isso, o Geógrafo pesquisador irá relacionar fatos que aparentemente teriam pouca ou nenhuma relação entre si, em uma primeira observação assistemática. E ao sistematizar sua observação por meio de dados, conjecturas e análises, o pesquisador pode então atingir aspectos essenciais do fato observado. (Venturi, 2008).

Paralelamente aos autores que trabalhavam com o conceito de paisagem, e por vezes concomitantemente, inseriam-se discussões acerca da análise sistêmica, ora para delinear uma porção da própria paisagem, como Bertrand, que considera o geossistema uma porção territorial de 100 a $10.000 \mathrm{~km}^{2}$, ora com uma distinção epistemológica de tratamento, empreendendo à análise sistêmica uma dinâmica própria. 
Essa análise sistêmica, em Sotchawa, vai gerar a classificação de Geossistemas (1978), que para ele significa dizer que o meio natural organiza-se em hierarquias funcionais, com classes diversas e subclasses, onde se estabelecem relações simultâneas. E para a caracterização do meio natural devem ser seguidos dois princípios: o da homogeneidade (ou geômeros) e o da diferenciação (ou geócoros).

Segundo SOTCHAVA (1978), os geossistemas, embora sejam considerados "fenômenos naturais", devem ser estudados à luz dos fatores econômicos e sociais que influenciam sua estrutura.

Cada categoria de Geossistema possui seu espaço paramétrico; a delimitação territorial depende da escala de análise e pode-se trabalhar em escala planetária, regional, ou local, pois em sua concepção não há um tamanho pré-definido de geossistema, mas sim uma base funcional e fisionômica. A fisionomia é sempre dada por algum aspecto relevante da paisagem, seja pelo relevo ou pela vegetação. A estrutura é devida aos materiais, solos e rochas. E a dinâmica - funcionalidade, ou processos - é a movimentação nas unidades de paisagem, definidas pelos fluxos de energia e matéria em seus elementos constituintes: ar, água, nutrientes e sólidos em deslocamento.

Para Bertrand, geossistema se define como a combinação interativa do potencial ecológico (relevo, clima e água), da exploração biológica (solo, vegetação e fauna) e da ação antrópica (apropriando-se dos recursos naturais), o qual "constitui uma boa base para os estudos de organização do espaço porque ele é compatível com a escala humana.

Tricart também se insere na analise sistêmica, no momento que afirma que tudo que faz parte da litosfera, tem uma ligação com os arranjos estruturais das litologias, que por sua vez tem uma ligação com as atividades tectônicas e essas com a energia do interior da terra. Para ele, a energia solar, a atmosfera, a vegetação, o solo, o subsolo, água e rochas interagem de maneira a formar um sistema. Este autor criou três tipos de classificação dos ambientes, ou meios morfodinâmicos:

- Meios estáveis: quando há o predomínio da pedogênese e onde o ambiente encontra-se em equilíbrio; 
- Meios intergrades: transição entre os outros dois (classificação teórica);

- Meios instáveis: predomínio da morfogênese.

A partir do relevo e dos fluxos de energia e matéria, ele busca explicar a dinâmica da paisagem. Energia Solar, Energia da Gravidade, Energia do Interior da Terra serão as responsáveis pela forma do relevo.

Ele afirma que "no momento atual, já não existe nenhum ecossistema que não seja modificado pelo homem, só que as modificações são de natureza diferente e de importância diversa" (Tricart, 1977, p. 17)

A partir, portanto, da consulta a esses autores que trabalharam com o conceito de paisagem, ora explicitamente, ora indiretamente, quando se referiam a um ecossistema, geossistema, ou domínio, conceitos integrados, portanto, ao de paisagem, foi possível delinear alguns aspectos a serem ressaltados, dentre os quais: a evolução cronológica de uma paisagem imutável (primeiro momento descrição) a outra em permanente mutação (segundo período - evolução); ou uma paisagem natural, para outra cultural; ou a velocidade de transformação da primeira em detrimento da segunda; ou o próprio dimensionamento pré-estabelecido por alguns autores, ordens de grandeza, em detrimento da liberdade de dimensionamento obtido pela bagagem do observador; ou ainda paisagens relacionadas ao input e output de energia, ou entrada e saída de energia formando uma energeticamente equilibrada contra outra em desequilíbrio (terceira fase funcionamento da paisagem); e a paisagem sistêmica; bem como paisagens perceptíveis a partir primordialmente de sua vegetação ou por meio de seu relevo, ou cobertura (urbanas p.ex.); homogeneidade e heterogeneidade, como forma de sua delimitação; a paisagem como uma resultante, uma combinação de fatores, uma realidade que reflete inúmeras relações, em constantes transformações.

Assim, a compreensão deste conceito e a apropriação de seu uso pelo geógrafo consistem no próprio enriquecimento à argumentação, uma vez que seu significado pode ser direcionado a qualquer área de estudo, em qualquer escala de trabalho, desde que aceita e compreendida pelo profissional envolvido na análise. 
Nos estudos de impacto ambiental, obrigatoriamente, o geógrafo utiliza-se deste conceito para a apreensão integrada da realidade analisada, seja diagnosticando a situação atual da paisagem a ser demonstrada no estudo da área, seja ao compreender seu funcionamento prognosticando a situação pretendida com a introdução do impacto a ser causado, no próprio mapeamento do lugar e de seu entorno.

Trabalhar com o conceito de paisagem mostra-se também bastante relevante no momento de se delinear a ocupação territorial tida na região de introdução do novo empreendimento, cuidando-se para a verificação das paisagens exteriores, ou das áreas de influência do mesmo, de modo a verificar sua viabilidade e adaptabilidade ao lugar, seja capacidade de absorção do impacto no local, seja pela própria lei de uso e ocupação do solo intrínseca ao município alvo.

O conceito de paisagem visto sob o prisma da integração dos meios físico, biótico e antrópico se torna imprescindível para a prática nos estudos ambientais, ora na análise sistêmica, em que o impacto em um deles, acaba por impactar os outros, ora na própria exigência dos órgãos ambientais em se apresentar estudos em que os impactos sejam analisados de forma integrada e não fragmentada.

Por fim, cabe mencionar que a própria lei do geógrafo $n^{\circ} 6.664$, de 26 de junho de 1979, a qual disciplina a profissão, prevê a possibilidade e legalidade de atuação profissional nos aspectos relacionados ao conceito de paisagem, assim habilitando o profissional a "interpretação das condições hidrológicas das bacias fluviais", na "caracterização ecológica e etológica da paisagem geográfica e problemas conexos", no "estudo e planejamento das bases físicas" e no "aproveitamento, desenvolvimento e preservação dos recursos naturais". (CREA, 2008).

\subsection{Espaço Geográfico}

Para a professora Ana Fani Alessandri Carlos "(...) o espaço é pensado como categoria de análise geográfica (...)" por se constituir na “(...) síntese das relações entre a sociedade e o meio circundante." (Carlos, 1979, p.1) 
Essa relação por muito tempo foi entendida como o próprio fazer da Geografia e ainda o é, porém tendo incorporado, na atualidade uma gama maior de abordagens e objetos de estudo; podendo-se afirmar, que a partir do último quarto do século $X X$, a Geografia brasileira, amparada nos teóricos da Geografia crítica, passa a incorporar também como objeto de estudo, a relação "homem $\mathrm{X}$ homem", a partir do marxismo e do entendimento do estudo das relações de exploração trazidas neste bojo.

Para a autora, o espaço geográfico é fruto do momento histórico da sociedade e de sua atividade produtiva, que amparada na divisão do trabalho e na evolução técnica irá redundar na modificação da estrutura da sociedade e, por conseguinte, no próprio espaço geográfico.

A organização do espaço geográfico, para ela, além de ser fruto do momento histórico, portanto estando em contínua modificação, é também fruto “... de uma necessidade humana de sobrevivência e preservação" gerada pelo trabalho humano, que por sua vez “... envolve uma organização social...” de cooperação (Carlos, 1979, p. 16)

A "categoria trabalho é de fundamental importância, na compreensão da organização espacial, como mediação entre a sociedade e o espaço. O trabalho modifica o meio apropriando-se dele e não simplesmente submetendo-se a ele." (Carlos, 1979, p. 21)

O espaço geográfico nunca deve ser visto como "o palco onde os homens habitam, pois a idéia de espaço não pode estar relacionada à de receptáculo, elemento passivo e inerte." Pois, "é a ação humana consciente que transforma o meio natural em espaço geográfico." (Carlos, 1979, p. 28) Esta ação humana é o próprio processo produtivo mediado pelo trabalho, determinando que "ao mesmo tempo em que através dele a sociedade produz sua existência", ela irá produzir "o espaço" (Carlos, 1979, p. 34)

Esta categoria de análise, o espaço geográfico, deve ser apreendida a partir da modificação imposta pelo homem à natureza num primeiro momento; e à segunda natureza, num outro, em lugares em que a transformação do espaço já se deu 
outrora, como por exemplo, nos grandes centros urbanos, com a construção, destruição e reconstrução incessante de novas porosidades e rugosidades inseridas pela ação humana.

Pode-se sintetizar que:

Pelas necessidades de produção, a sociedade através do trabalho vai organizando o espaço criando infra-estrutura, prédios e casas, mudando o curso dos rios, fazendo pontes, portos e aterros, modificando a paisagem e criando um esboço que permita atingir as metas fixadas pelo modo de produção geral. Isso não quer dizer, que a organização do espaço está reduzida à infra-estrutura, o processo de produção e consequentemente o processo de circulação só existem, só se realizam quando se produz concomitantemente a produção do espaço; essa organização também ditará o comportamento da sociedade. (Carlos, 1979, p. 85)

Já Milton Santos demonstra que para a compreensão do conceito de espaço, como um conjunto indissociável de sistema de objetos e de sistemas de ações, são necessárias algumas categorias de estudo, as quais permitem a correção em sua análise, entre estas estão "a paisagem, a configuração territorial, a divisão territorial do trabalho, o espaço produzido ou produtivo, as rugosidades e as formasconteúdo." (Santos, 2002, p. 22). Bem como se faz necessária a inserção dos recortes, como o de região e de lugar, de redes e de escalas; junto a questões de uma ordem mundial ou de uma ordem local.

O estudo dessas categorias internas "supõe o reconhecimento de alguns processos básicos, originariamente externos ao espaço: a técnica, a ação, os objetos, a norma e os eventos, a universalidade e a particularidade, a totalidade e a totalização, a temporalização e a temporalidade, a idealização e a objetivação, os símbolos e a ideologia." (Santos, 2002, p. 23)

As técnicas são consideradas por ele "um conjunto de meios instrumentais e sociais, com os quais o homem realiza sua vida, produz e, ao mesmo tempo, cria espaço. (Santos, 2002, p. 29) e por meio delas é que se dá a relação entre o homem e o meio.

Essas técnicas, distribuídas desigualmente, por vezes, num mesmo território, datam elementos técnicos provenientes de épocas diferentes, que podem emperrar a própria evolução de novos objetos técnicos naquele lugar. As técnicas, mesmo nos 
dias atuais não devem ser consideradas universais ou homogêneas, uma vez que a atuação de diversos atores num determinado espaço podem confluir para a difusão ou não das mesmas.

As técnicas são datadas e os objetos técnicos através dos tempos demonstram as sucessivas histórias do lugar. "A técnica nos ajuda a historicizar, isto é, a produzir uma Geografia como ciência histórica." E "por intermédio das técnicas que o homem, no trabalho, realiza essa união entre espaço e tempo" (Santos, 2002, p. 49, 54).

O espaço é formado por objetos técnicos datados, produzidos não só pelo processo direto do trabalho, mas por distintos processos de trabalho, os quais constituem a técnica particular de um determinado período e por vezes são específicas de um determinado lugar.

O espaço para Milton Santos (2002) é definido com "um conjunto indissociável de sistemas de objetos e de sistemas de ações" onde a história se dá. Esses objetos, outrora naturais, foram substituídos por objetos fabricados, objetos técnicos, objetos mecanizados e objetos cibernéticos, exemplificados por cidades, hidroelétricas, ou estradas, os quais condicionam os sistemas de ações, numa relação de interdependência. "O enfoque do espaço geográfico, como o resultado da conjugação entre sistemas de objetos e sistemas de ações, permite transitar do passado ao futuro, mediante a consideração do presente." (Santos, 2002, p. 100) Para ele "as forças produtivas são relações de produção, as relações de produção são forças produtivas" (Santos, 2002, p. 64).

As ações são subordinadas a normas e resultam de necessidades naturais ou criadas. "Essas necessidades: materiais, imateriais, econômicas, sociais, culturais, morais, afetivas, é que conduzem os homens a agir e levam a funções." E "essas funções, de uma forma ou de outra, vão desembocar nos objetos. (Santos, 2002, p. $82,83)$.

As ações, ou eventos resultantes das ações humanas comandam, através do uso diversificado do trabalho e da informação, inovações no tempo e no espaço, reorganizando os lugares. 
Outra categoria de estudo necessária a compreensão do conceito de espaço de Milton Santos é a "paisagem" a qual já foi trabalhada nesta dissertação por outros autores, ainda assim, faz-se necessária a apresentação da diferenciação que este autor apresenta em relação ao espaço, como segue:

Paisagem e espaço não são sinônimos. A paisagem é o conjunto de formas que, num dado momento, exprimem as heranças que representam as sucessivas relações localizadas entre homem e natureza. O espaço são essas formas mais a vida que as anima.

A palavra paisagem é freqüentemente utilizada em vez da expressão configuração territorial. Esta é o conjunto de elementos naturais e artificiais que fisicamente caracterizam uma área. A rigor, a paisagem é apenas a porção da configuração territorial que é possível abarcar com a visão. Assim, quando se fala em paisagem, há, também, referência à configuração territorial e, em muitos idiomas, o uso das expressões é indiferente.

A paisagem se dá como um conjunto de objetos reais concretos. Nesse sentido, a paisagem é transtemporal, juntando objetos passados e presentes, numa construção transversal. O espaço é sempre um presente, uma construção horizontal, uma situação única. Cada paisagem se caracteriza por uma dada distribuição de formas-objetos, providas de um conteúdo técnico específico. Já o espaço resulta da intrusão da sociedade nessas formas-objetos. Por isso, esses objetos não mudam de lugar, mas mudam de função, isto é, de significação de valor sistêmico. A paisagem é, pois, um sistema material e, nessa condição, relativamente imutável: o espaço é um sistema de valores, que se transforma permanentemente.

O espaço, uno e múltiplo, por suas diversas parcelas, e através do seu uso, é um conjunto de mercadorias, cujo valor individual é função do valor que a sociedade, em dado momento, atribui a cada pedaço de matéria, isto é, cada fração da paisagem.

A paisagem existe através de suas formas, criadas em momentos históricos diferentes, porém coexistindo no momento atual. No espaço, as formas de que se compõe a paisagem preenchem, no momento atual, uma função atual, como resposta às necessidades atuais da sociedade. Tais formas nasceram sob diferentes necessidades, emanaram de sociedades sucessivas, mas só as formas mais recentes correspondem a determinações da sociedade atual. (Santos, 2002, p. 103-104)

autor acredita que a paisagem se conforma como algo relativamente estático (em relação ao espaço), sendo aquela fração do território passível de ser abarcada com a visão, fortemente ligada ao concreto, aos objetos contidos naquele lugar, separada das ações humanas do presente, diferentemente de espaço, que é animado por essas ações humanas atuais, as quais atribuem um valor ao lugar e aos objetosconteúdo, tanto os do presente, como os do passado - agora com novos valores atribuídos. 
O espaço constitui a matriz sobre a qual as novas ações substituem as ações passadas. É ele, portanto, presente, porque passado e futuro.

Só por sua presença, os objetos técnicos não têm outro significado senão o paisagístico. Mas eles aí estão também em disponibilidade, à espera de um conteúdo social. (Santos, 2002, p. 104-105)

Durante a guerra fria, os laboratórios do pentágono chegaram a cogitar da produção de um engenho, a bomba de nêutrons, capaz de aniquilar a vida humana em uma dada área, mas preservando todas as construções. O Presidente Kennedy afinal renunciou a levar a cabo esse projeto. Senão, o que na véspera seria ainda espaço, após a temida explosão seria apenas paisagem. Não temos melhor imagem para mostrar a diferença entre esses dois conceitos. Ao nosso ver, a questão a colocar é a da própria natureza do espaço, formado, de uma lado, pelo resultado material acumulado das ações humanas através do tempo, e, de outro lado, animado pelas ações atuais que hoje lhe atribuem um dinamismo e uma funcionalidade. (Santos, 2002, p. 106)

Quando a sociedade age sobre o espaço, ela não o faz sobre os objetos como realidade física, mas como realidade social, formas-conteúdo, isto é, objetos sociais já valorizados aos quais ela (a sociedade) busca oferecer ou impor um novo valor (Santos, 2002, p. 109).

A paisagem está contida no espaço, nele são acrescidas as ações sociais, ações estas que transmitem novos valores às formas-conteúdo, transformando o espaço em um dado físico e social, "o espaço geográfico é um dado espacial" e "deve ser considerado como algo que participa igualmente da condição do social e do físico, um misto, um híbrido." (Santos, 2002, p. 75, 86).

A noção de totalidade sugere que todas as coisas presentes no universo formam uma unidade e essa não é explicada pela soma das partes que a formam, mas o oposto, a totalidade que explica as partes. Portanto para se pensar a totalidade é necessário o desmembramento de suas partes, sua divisão, como maneira de não se esvaziar o movimento do conhecimento da totalidade.

A totalização por sua vez, seria o processo empreendido na busca do encontro da totalidade, seria a ação, o movimento, "para alcançar a verdade total, é necessário reconhecer o movimento conjunto do todo e das partes, através do processo de totalização" (Santos, 2002, p. 120)

Em um movimento semelhante, tem-se o universal e o particular, como este último se originando no primeiro, ou seja, o particular se origina do universal e nele está contido. 
Os símbolos e a ideologia também são categorias de estudo necessárias ao entendimento de conceito de espaço de Milton Santos. Os símbolos, por vezes, são criados pela ideologia, e acabam já nascendo como ideologia e como realidade ao mesmo tempo. Porém, com o movimento da sociedade, com as novas divisões territoriais do trabalho, os símbolos requerem uma readaptação de significado, as quais são empreendidas por seus ideólogos.

A divisão do trabalho, por sua vez, pode ser entendida como "o motor da vida social e da diferenciação espacial". A qual, "movida pela produção, atribui, a cada movimento, um novo conteúdo e uma nova função aos lugares." (Santos, 2002, p. 129 , 131). É por essa divisão territorial do trabalho, e, sobretudo, com o acréscimo das técnicas, que o poder de intervenção do homem na natureza se eleva em escala.

A divisão territorial do trabalho empreendida num determinado tempo histórico, define a formação socioespacial de um lugar, as quais vão formar a "matriz das espacialidades vividas". Desta forma "cada lugar é teatro de tempos "externos" múltiplos. Na verdade, a partir do tempo mundial, que é o tempo externo absoluto, os outros tempos comparecem como tempos internos." (Santos, 2002, p. 139).

Não obstante "a divisão social do trabalho é freqüentemente considerada como a repartição (ou no mundo, ou no lugar) do trabalho vivo. Essa distribuição vista através da localização dos seus diversos elementos, é chamada de divisão territorial do trabalho." (Santos, 2002, p. 139). Essas duas são interdependentes e necessitam do trabalho morto e do trabalho vivo para se realizarem, os quais simplificadamente seriam representados, o primeiro, por recursos disponíveis num lugar, tal como uma madeira, ou uma ferramenta, ambos já com algum trabalho vivo envolvido, os quais (madeira ou ferramenta) poderão ser utilizados pelo trabalho vivo para empreenderem um novo produto, o trabalho vivo, portanto é a ação que se faz do uso do trabalho morto.

As rugosidades representam a espacialização da acumulação do trabalho num determinado lugar, as quais são representadas "como forma, espaço construído, paisagem, o que resta do processo de supressão, acumulação, superposição, com 
que as coisas se substituem e acumulam em todos os lugares. (Santos, 2002, p. 140). Essas combinações fazem de cada lugar um espaço único.

Assim, uma rugosidade, por exemplo, uma barragem, vai representar a técnica aplicada no momento da construção da mesma, imprimindo a esta rugosidade também um conteúdo temporal, “... o espaço testemunha a realização da história, sendo, a um só tempo, passado, presente e futuro." (Santos, 2002, p. 156)

Milton Santos chama a atenção também para o chamado "encurtamento das distâncias", a partir da idéia de que o tempo suprime o espaço, graças aos progressos no uso da velocidade pelas pessoas, coisas e informação. Ele na verdade rebate esta corrente de pensamento, quando afirma que "as informações não atingem todos os lugares (...) há inúmeros filtros intermediários (...) que interferem na natureza da informação (...) podendo descaracterizar o produto". Para ele “... não se trata da supressão do espaço: o que se dá é um novo comando da distância. E o espaço não é definido exclusivamente por essa dimensão." (Santos, 2002, p. 202).

O autor traz para a discussão da formação do espaço, dois atores que se interrelacionam de modo a se estabelecerem, e reorganizarem o lugar como melhor the convierem, são eles a mais-valia, denominada de motor único, a qual contribui para ampliar e aprofundar o processo de internacionalização, seja da produção, do dinheiro, do crédito, da dívida, consumo, ou da política e da cultura e; as empresas globais, que operam em um âmbito menos restrito do que as multinacionais, controlando as forças produtivas científicas e técnicas, comercialização, distribuição e a gestão financeira.

Para a apreensão do espaço, Milton Santos aborda também os "objetos", os quais são rapidamente trocados, revalorizados e desvalorizados, fazendo com que o espaço esteja sempre em constante transformação, em sua fisionomia, fisiologia, estrutura, aparência e em suas relações. Para ele "a grande distinção entre o hoje e o ontem é que os objetos eram pouco numerosos, viviam em comunhão conosco e nos eram subordinados." Já hoje, os objetos técnicos se apoderam do cotidiano, "a submissão do produtor diante do objeto produzido é, uma das causas da alienação contemporânea." (Santos, 2002, p. 214). 
E se hoje, os espaços encontram suas singularidades, devidas aos fatores já mencionados como a superposição de divisões territoriais do trabalho, ou rugosidades históricas, por exemplo. Sobre os objetos técnicos, ou objetos científicotécnicos, "cuja produção tem como base intelectual a pesquisa e não a descoberta ocasional, a ciência e não a experiência" (Santos, 2002, p. 215), sendo ainda informacionais, pois são chamados a produzir um trabalho, que é informação; para eles a distribuição é mais homogênea, não poupando espaços, assim esses objetos, por vezes, formadores de rugosidades, se espraiam por quase todos os cantos do mundo, sejam eles hidrelétricas, edifícios, estradas de ferro, ou computadores.

Neste momento da reflexão empreendida acerca do espaço, tem-se a sistematização de três maneiras de apreensão do meio geográfico, o meio natural, o meio técnico e o meio técnico-científico-informacional, sendo o primeiro relacionado ao meio natural, quando o homem escolhia da natureza as condições ideais para a base material da vida em grupo, já constituindo em uma técnica de domesticação da natureza, como exemplos tinham-se o pousio da terra e a agricultura itinerante; já o meio técnico convive com o espaço mecanizado e com objetos técnicos e culturais, o número e quantidade deles varia, assim como sua distribuição pelo mundo; o meio técnico-científico-informacional, datado do período pós-segunda guerra mundial, tomado corpo nos anos 1970 é marcado pela união da técnica e da ciência em favor do mercado, e seu funcionamento é também informação, sua disseminação pelo globo é homogênea. "Da mesma forma como participam da criação de novos processos vitais de novas espécies (animais e vegetais), a ciência e a tecnologia, junto com a informação, estão na própria base da produção, da utilização e do funcionamento do espaço e tendem a constituir o seu substrato." (Santos, 2002, p. 238).

Não obstante "os espaços assim requalificados atendem sobretudo aos interesses dos atores hegemônicos da economia, da cultura e da política e são incorporados plenamente às novas correntes mundiais. O meio técnico-científico-informacional é a cara geográfica da globalização. "(Santos, 2002, p. 239)

O conceito de região é também discutido pelo autor, "as regiões são o suporte e a condição de relações globais que de outra forma não se realizariam. (Santos, 2002, 
p. 246). Para ele, mesmo no estágio atual de globalização, não se deve prescindir deste conceito, o qual é construído a partir da distinção das outras entidades, vizinhas ou não. Desta feita, ele afirma que o que explica a região não é sua longevidade, esta agredida pela globalização, o que a faz é a sua coerência funcional. "A região continua a existir, mas com um nível de complexidade jamais visto pelo homem." (Santos, 2002, p. 247).

Inseridos no espaço, os lugares se distinguem "pela diferente capacidade de oferecer rentabilidade aos investimentos". Essa rentabilidade é variável dependendo da capacidade de o lugar oferecer uma "ordem técnica (equipamentos, infraestrutura, acessibilidade) e organizacional (leis, locais, impostos, relações trabalhistas, tradição laboral)". Assim explicitada seria uma "forma de considerar a valorização do espaço." (Santos, 2002, p. 247-248).

Neste contexto, a introdução do conceito de espaço produtivo, o qual aplicado a um lugar, em função de uma atividade ou do conjunto das mesmas, em que as condições artificiais criadas pelo homem se sobressaem às naturais. Esta produtividade espacial pode ser interrompida no momento em que outro lugar ofereça condições mais vantajosas.

Deste modo "as formas novas, criadas para responder a necessidades renovadas, tornam-se mais exclusivas, mais endurecidas, material e funcionalmente, mais rígidas tanto do ponto de vista das técnicas implicadas como de sua localização. Passamos de uma cidade plástica a uma cidade rígida. (Santos, 2002, p. 251).

Essa (re)produção baseada na técnica e na ciência (re)transmite ao lugar um valor às atividades que ali se localizam, "ao mesmo tempo em que aumenta a importância dos capitais fixos (estradas, pontes, silos, terra arada etc.) e dos capitais constantes (maquinário, veículos, sementes especializadas, fertilizantes, pesticidas etc.) aumenta também a necessidade de movimento, crescendo o número e a importância dos fluxos, também financeiros, e dando um relevo especial à vida de relações." (Santos, 2002, p. 240).

As redes se inserem na discussão no momento em que são consideradas sociais, políticas e técnicas, globais e locais "quanto mais avança a civilização material, mais 
se impõem o caráter deliberativo na constituição das redes" e assim se cria o "espaço da transação", "porção do espaço total cujo conteúdo técnico permite comunicações permanentes, precisas e rápidas entre os principais atores da cena mundial." (Santos, 2002, p. 265).

As redes, graças aos progressos das técnicas, cada vez mais são globais, embora não atinjam todos os lugares, e em outros haja uma superposição das mesmas, sejam elas redes de informação, transportes, produtivas, ou de comercio. O global surge "como primeira totalidade, empiricizada por intermédio das redes." Enquanto "um país e um Estado - uma formação socioespacial" são considerados pelo autor, uma segunda totalidade, e por fim "o lugar é a terceira totalidade, onde fragmentos de rede ganham uma dimensão única e socialmente concreta" (Santos, 2002, p. 270). As redes cumprem a função do favorecimento da fluidez para a circulação de idéias, dinheiro, ou produtos, realizados através de objetos, sejam eles aeroportos ou gasodutos, de forma que já não é mais a produção que preside a circulação, mas o contrário.

Expostos esses diversos conceitos internos ao entendimento de espaço, o próprio autor releva que "a geografia deve trabalhar com uma noção de espaço que nele veja uma forma-conteúdo e considere os sistemas técnicos como uma união entre tempo e matéria, entre estabilidade e história." (Santos, 2002, p. 279), e que esta nova etapa histórica se distingue pelo meio técnico-científico-informacional se sobrepondo ao meio natural e ao próprio meio técnico, como forma de constituir espaços da racionalidade, como suporte das principais ações globalizadas.

Em suas considerações finais, Milton Santos afirma que "não existe um espaço global, mas, apenas, espaços da globalização. O mundo se dá, sobretudo como norma, ensejando a espacialização, em diversos pontos, dos seus vetores técnicos, informacionais, econômicos, sociais, políticos e culturais." E o "território termina por ser a grande mediação entre o mundo e a sociedade nacional e local", uma vez que é nos lugares que se materializam as alterações específicas empreendidas pelos atores sociais. "Para se tornar espaço, o mundo depende das virtualidades do lugar. Nesse sentido pode-se dizer que, localmente, o espaço territorial age como norma." (Santos, 2002, p. 337, 338). 
A compilação das principais categorias internas inerentes ao conceito de espaço de Milton Santos em sua obra "A Natureza do Espaço" fez-se necessária como forma de apreender com mais profundidade este conceito de "um sistema de objeto e de ações", para o qual se justifica a inserção nesta dissertação no momento em que o licenciamento ambiental de empreendimentos modificadores da paisagem constitui a própria animação do conjunto de formas da paisagem, ou seja, a própria transformação da mesma pelo homem, com um propósito social.

Assim, a introdução de novas rugosidades na paisagem pelo homem, ou implantação de novos objetos, sejam eles edifícios, hidrelétricas ou rodovias são considerados pelo autor, a própria animação da paisagem, objetos esses, constantemente trocados, revalorizados e desvalorizados, relegando ao espaço uma constante transformação, em sua fisionomia, fisiologia, estrutura, aparência e em suas relações.

Esses objetos formadores de rugosidades implicam em um conteúdo histórico datado, os quais conformam um conteúdo temporal, delegando ao conceito de espaço "a matriz sobre a qual as novas ações substituem as ações passadas. É ele, portanto, presente, porque passado e futuro."

Desta forma pensado, o conceito de espaço pode sair do plano teórico para ser aplicado em estudos de impacto ambiental, embasando conceitualmente e enriquecendo os mesmos, até mesmo como forma de caracterizar um trabalho elaborado por um profissional da Geografia, com seu vocabulário próprio e todo seu aporte formador. Assim, levando aos estudos um enriquecimento teórico-conceitual relevante, e não apenas incorporando os jargões de outros profissionais, que muitas vezes, não se adéquam à realidade da Geografia, com sua riqueza de abordagens e espectro de atuação.

\subsection{Região}

O termo região, freqüentemente é empregado nas mais diversas modalidades cotidianas, região quente, região chuvosa, região perigosa, região em que se 
trabalha, região de difícil acesso, entre inúmeros outros usos, sem o caráter que é Ihe dado na Geografia.

Essa palavra é empregada desde a antiguidade "com destaque nos estudos sobre as diferenças e os contrastes da superfície da Terra, que foi denominado, pelos gregos, de estudo corográfico" (Lencioni, 1999, p. 187).

Para Lencioni:

Aos gregos podemos creditar a primeira regionalização concebida com algum método. Quem primeiro traçou um mapa-múndi e procedeu a uma regionalização da Terra foi Hecateu de Mileto (550-475 a.C.), divulgando a regionalização de Pitágoras, na qual as cinco zonas climáticas da Terra corresponderiam a uma zona tórrida, uma temperada, duas frias e, ainda, uma zona tropical. Mas é em Estrabão (63 a.C-25 d.C) que encontramos o marco inaugural da geografia regional. (Lencioni, 1999, p. 187, 188).

Estrabão, embora considerasse a geometria a base da Geografia, não a utilizava em suas regionalizações; seus recortes regionais já eram estabelecidos a partir da composição territorial das civilizações.

Da mesma forma:

Dentre as contribuições para o desenvolvimento da geografia regional, gostaríamos de destacar Al-Idirisi, século XII, que, seguindo a divisão de mundo de Ptolomeu, elaborada com parâmetro no clima, criou uma divisão mais detalhada da Terra, expressa em 70 regiões, tendo procedido à descrição de cada uma delas, ilustrando-as com um mapa. Mas foi com Bernhard Varenius, no século XVII, que o conhecimento geográfico assumiu a distinção entre geografia geral e geografia especial, esta última com o sentido de geografia regional. (Lencioni, 1999, p. 188).

Para Lencioni (1999), os estudos regionais apresentaram a possibilidade de se criar uma identidade para a Geografia, servindo como um procedimento metodológico de análise, relacionando os fenômenos humanos e físicos numa determinada área. "Por isso é que se consagraram os estudos regionais como a alternativa de manutenção da unidade da disciplina geográfica." (Lencioni, 1999, p. 189).

Com Vidal de La Blache, a Geografia se insere de forma contundente nos estudos regionais, para ele a "ciência geográfica deveria observar e compreender a singularidade dos lugares." De tal forma a considerar "a síntese regional como o 
objetivo último da tarefa do geógrafo, o único terreno sobre o qual ele encontra a si mesmo" (Lencioni, 1999, p. 189).

Tal foi a popularidade desses estudos regionais, que a disseminação dos mesmos acarretou em outro problema, qual seja: cada estudo regional, abordava dados particulares, de tal modo, um mesmo lugar podia apresentar estudos regionais distintos, pois não haviam princípios ou leis gerais no conhecimento da realidade.

Para La Blache, a região era evidenciada na paisagem, contrariamente a Alfred Hettner, para o qual a região era uma construção intelectual do pesquisador, Richard Hartshorne, por sua vez, trabalhava com a "diferenciação de áreas" produzida da inter-relação entre os fenômenos.

A crítica a esses autores é empreendida, a partir dos teóricos do positivismo lógico, para os quais "a busca de rigor científico e de uma universalidade, de homogeneização de procedimentos e de unidade, não só em relação à linguagem, mas também quanto ao método, acabou se constituindo no principal parâmetro da geografia..." (Lencioni, 1999, p. 191).

Com essa corrente teórica houve uma matematização do espaço, o qual deveria ser compreendido através de uma ordem, de uma lógica em sua organização. Assim a Geografia, e propriamente a região passaram a integrar o chamado planejamento regional.

Como decorrência, no positivismo lógico, "(...) a região se tornou um instrumento técnico-operacional, a partir do qual se procurou organizar o espaço." (Lencioni, 1999, p. 192).

Também:

$\mathrm{Na}$ análise regional, utilizou-se da teoria geral dos sistemas tentando resolver várias questões, como a delimitação funcional da região, a definição da escala regional e a coesão do conteúdo regional. Menos importante era reconhecer ou determinar as regiões historicamente definidas; mais relevante era classificar as regiões, hierarquizá-las e verificar suas relações funcionais. (Lencioni, 1999, p.192). 
$\mathrm{Na}$ "linguagem geográfica, se vulgarizou a expressão subespaço para se referir à região. Os questionamentos teóricos da geografia passaram muitas vezes a se situar como modelos." (Lencioni, 1999, p. 192).

Essa forma elaborada de Geografia é abalada no momento em que se iniciaram as críticas a esses modelos como procedimentos de análise, em que o interesse pelas particularidades foi colocado em último plano, esses críticos não acreditavam em processos puramente espaciais, achando necessária a inclusão dos conteúdos sociais à discussão.

Assim, introduzem-se na Geografia, outras correntes de pensamento, tais como o marxismo e a fenomenologia que buscavam uma explicação para os fenômenos regionais, a partir de novos parâmetros, os sociais.

Com a fenomenologia, o enfoque era dado a partir da percepção do observador, sua apreensão da realidade era dada sem conhecimentos pré-estabelecidos, através do "vivido é que o indivíduo se põe em contato com o mundo dos objetos exteriores." (Lencioni, 1999, p. 193) Essa se colocava como uma metodologia dessa corrente de pensamento.

A partir, portanto, da percepção contida no indivíduo, os estudos regionais passaram a incorporar a identidade do pertencimento, ou seja, a identidade dos homens com a região passou a estar no centro da discussão. A região, na fenomenologia é vista como "uma construção mental, individual, mas também submetida à subjetividade coletiva de um grupo social." (Lencioni, 1999, p. 194).

Contudo, como revelado pela autora, o embate entre positivismo lógico e fenomenologia, acaba por enfraquecer esta última, uma vez que surgiam críticas acerca da falta de uma metodologia mais consistente por um lado, e, por outro, por ter negligenciado os aspectos naturais em detrimento dos humanos.

Sob a égide marxista, que destacava a relação do homem com a natureza e com outros homens sob a perspectiva social e histórica, a região era tida como parte de uma totalidade histórica, com a "preocupação, naquele momento, em denunciar as injustiças e as desigualdades sociais do capitalismo..." (Lencioni, 1999, p. 196) 
A região, no marxismo, privilegiava, portanto, as noções de desenvolvimento desigual e subdesenvolvimento, por exemplo, passando a ser vistas como produto de uma divisão territorial do trabalho.

Para a autora:

Atualmente, com o processo de globalização essa reestruturação traz à tona o questionamento da pertinência da escala de análise regional e também o esclarecimento de sua relevância como instância particular de análise que se situa entre o local e o global. (Lencioni, 1999, p. 199).

Assim "a noção de região é relevante para a compreensão do recorte espacial e se constitui uma categoria de análise própria da Geografia. Como outras noções próprias da Geografia, contém a possibilidade de revitalizar e renovar o pensamento geográfico." (Lencioni, 1999, p. 203).

Para o enriquecimento da abordagem do conceito de região faz-se necessário, neste momento, a incursão nos textos de outros autores que também trabalharam com o tema. Milton Santos assinalou que "nas condições atuais da economia universal, a região já não é uma realidade viva, dotada de coerência interna. Definida sobretudo do exterior, seus limites mudam em função dos critérios que the fixamos. Por conseguinte, a região não existe por si mesma." (Santos, 1978, p. 10). Para ele, alguns fatores apontavam para esta nova maneira de pensar a região, entre eles os progressos no domínio dos transportes e comunicações, além da expansão da economia internacional.

Para Armando Corrêa da Silva "a categoria de região é posterior à categoria de território, porque a região é o território já ocupado e onde se desenvolveu uma organização do espaço que o torna determinação de um modo de vida. É por isso que a região é o lugar em que se nasce ou ao qual se pertence." (Silva, 1986, p. 3031). Para este autor, os conceitos e as categorias são representações da realidade e a região, a paisagem e o espaço, abordadas nesta dissertação, são para ele, categorias fundamentais do conhecimento geográfico, assim como são o lugar, a área, território, população e habitat.

Roberto Lobato Corrêa também trabalhou com esta categoria de estudo, buscando as raízes históricas do termo região, a partir do verbo latim regere, que significa 
governar, atribuindo "à região, em sua concepção original, uma conotação eminentemente política." (Corrêa, 1997, p. 183). E também resgatando as acepções do uso de região dada pelos geógrafos, esta surgindo primeiramente como região natural, em que a combinação de elementos da natureza, como clima, vegetação e relevo caracterizavam uma porção do território. Depois a região-paisagem, vista pela transformação da paisagem natural em paisagem cultural, com matriz no historicismo de base neokantiana. E uma terceira acepção, na qual a região é estabelecida de acordo com os critérios do pesquisador, portanto não eliminando as duas concepções anteriores, por vezes intercalando-as.

Para a atualidade, Corrêa aponta o desafio da abordagem de região "em sua tarefa de tornar inteligível a ação humana no tempo e no espaço." No qual "o embate entre o velho (a organização sócio-espacial preexistente) e o novo (novos elementos econômicos e culturais) em cada uma das regiões, (...) acaba levando ao desfazer da velha região e o refazer de outra, nova, mas que contém traços da antiga. (Corrêa, 1997, p. 194).

Nigel Thrift, por sua vez, aponta que a Geografia regional, na atualidade, pode indicar novos caminhos de estudo:

Certamente os lampejos dessa nova espécie de geografia regional podem ser vistos no súbito aparecimento de trabalho social e cultural que está atualmente ocorrendo acerca de questões como gênero, sexualidade e etnias. A força deste trabalho reside em sua atenção para com a construção de espaços localizados de significado, fora de relações globais de poder e conhecimento. (Thrift, 1996, p. 242)

Para Daniel Faucher, duas características são fundamentais, nesta fase recente, para a delimitação de uma região: o crescimento das cidades e a revolução dos meios de comunicação. O crescimento das cidades representa para ele, um mundo de relações possíveis e o surgimento das nodalidades. Os progressos da urbanização na França fazem mudar o conteúdo da noção de região. "La unidad regional es ahora menos uma unidad de terreno, uma unidad de clima, uma identidad de gêneros de vida que uma diversidad coherente." Para ele, as regiões podem criar amplas harmonias em benefício de todos e de cada um, e a realização da região não se dá pelas uniformidades e sim pela diversidade das atividades 
complementares. "Cuantas más posibilidades diversas pero solidárias englobe la region, más posibilidades tendrá de vivir y de durar." (Faucher, 1982, p. 286, 288). Assim, esse novo tipo de região pode também ser considerada, região nodal, a qual é estabelecida a partir das relações entre coisas e lugares.

David Grigg afirma que região deve ser entendida como "resultado de um método de classificação de áreas" em que "o sistema de regiões só é estabelecido como primeiro passo de uma pesquisa geográfica." (Grigg, 1974, p. 34, 53). A escolha de critérios do pesquisador para o dimensionamento da região é muito particular, uma construção calcada em modelos criados pelo geógrafo, portanto a região delimitada por este pesquisador pode ser relevante apenas para ele, da mesma forma, a representação de uma região por meio de um mapa o seria, pois um mapa geomorfológico de uma região, por exemplo, pode ser útil apenas para aquele pesquisador, enquanto que se um mesmo mapa dessa região fosse elaborado de modo a constar estradas e pontos turísticos, sua utilidade poderia ser alçada aos turistas que visitam o mesmo local.

E, por fim, Ruy Moreira, aponta que "a região não declinou todavia de importância, tanto no espaço real quanto no da teorização." (Moreira, 1997, p. 2).

A partir, portanto, do contato com diversos autores que escreveram sobre região, foi possível verificar que a maioria se referia, de alguma forma, a Paul Vidal de La Blache que, afinal de contas, é tido como pioneiro em estudos regionais. Igualmente presente em muitos textos foram regiões baseadas em aspectos naturais, num primeiro momento; depois, regiões delimitadas por critérios de homogeneização; na sequência, o critério para a classificação se alicerça no olhar do observador, o qual pode ser dimensionado a partir de características físicas; mas o mais comum, foi a somatória a características sociais; ou ainda critérios de heterogeneidade; e mais recentemente de nodalidade, de mobilidade ou fluidez; ressaltando-se que na maioria dos casos, esses critérios não são excludentes em relação aos anteriores, pelo contrário, acabam incorporando-os e sobrepondo-os como metodologia.

Assim, a utilidade do conceito de região para os estudos ambientais e particularmente para o geógrafo que vier a empregá-lo reside na própria delimitação 
das áreas de estudo (olhar do observador), para as quais ele irá empregar esforços de compreensão a partir de atributos próprios verificados em loco.

Nos estudos de impacto ambiental são exigidas as delimitações da área de influência direta e indireta do empreendimento a ser licenciado, as quais, em última instância, podem ser consideradas a região em que o mesmo se encontra, pois para a definição, por exemplo, da área afetada por uma obra qualquer, o critério utilizado, por vezes, pode ser o de homogeneidade do entorno para formar este recorte, por meio de suas características físicas (relevo, bacia hidrográfica etc.), bióticas (tipo de domínio florestal), ou antrópicas (áreas ocupadas por agricultura, residenciais, densamente urbanizadas etc.).

Portanto, a justificativa do conceito de região para o geógrafo atuante em licenciamento ambiental, está no próprio enriquecimento de seu trabalho, a partir do emprego de categorias e conceitos próprios de seu arcabouço teórico, de forma a imprimir sua presença nos estudos ambientais com as características inerentes de sua formação acadêmico-científica. Muitos estudos contidos nos EIAs possuem apenas uma tabela informando quais são as áreas de influência do novo empreendimento, sem a mínima preocupação em demonstrar o porquê destas escolhas. O geógrafo, com sua formação, tende a elaborar melhor a explicação na definição das áreas de influência direta, indireta e diretamente afetada, tendo no conceito de região uma ferramenta do arsenal teórico e sua transposição para a prática profissional.

Não obstante, a própria lei do geógrafo, prevê a possibilidade e legalidade de atuação profissional nos aspectos regionais, seja na própria "delimitação e caracterização de regiões, sub-regiões geográficas naturais e zonas geoeconômicas, para fins de planejamento e organização físico-espacial" no "equacionamento e solução, em escala nacional, regional ou local, de problemas atinentes aos recursos naturais do País", seja "no zoneamento geo-humano, com vistas aos planejamentos geral e regional", assim como "na pesquisa de mercado e intercâmbio comercial em escala regional e inter-regional", na "política de povoamento, migração interna, imigração e colonização de regiões novas ou de revalorização de regiões de velho povoamento", também "no estudo físico-cultural 
dos setores geoeconômicos destinados ao planejamento da produção", na "estruturação ou reestruturação dos sistemas de circulação", bem como "no levantamento e mapeamento destinados à solução dos problemas regionais" e "na divisão administrativa da União, dos Estados, dos Territórios e dos Municípios" (CREA, 2008).

\subsection{Procedimentos de Pesquisa}

Foram expostas algumas das categorias de estudo da Geografia: a paisagem, o espaço, a região; e pontualmente: o domínio e o geossistema; todos fazendo parte de um universo maior de teorias e conceitos intrínsecos a esta ciência, determinantes na formação de seus cientistas e profissionais, e os quais subsidiarão a elaboração da sequência desta dissertação. Faz-se necessário agora, a demonstração dos procedimentos de pesquisa e trabalho necessários para o atendimento dos objetivos específicos propostos neste estudo.

Retomando e orientando-se pelos objetivos da pesquisa, para a realização de uma revisão das atividades pertinentes aos geógrafos junto ao CREA - Conselho Regional de Engenharia e Arquitetura será necessário explicitar o que a Lei $n^{\circ}$ 6.664, de 26 de junho de 1979, que disciplina a profissão, determina como atividades e funções deste profissional.

Quanto à formação do geógrafo, em seus aspectos teórico, técnico e crítico, esta apreciação será subsidiada por meio da análise do Plano de Metas Acadêmicas do Departamento de Geografia - período 2004-2008.

Já, para a realização da comparação entre as atividades constantes na Lei que disciplina a profissão de geógrafo e as que na prática foram realizadas pelos mesmos, dentro dos EIAs, decidiu-se, com critério de amostragem, pela realização de uma pesquisa em 40 estudos de impacto ambiental, para a verificação da participação dos geógrafos em quantidade e em que nível de participação, para saber em quais capítulos houve a contribuição deste profissional.

Para analisar criticamente a perda de (ou o pouco) espaço de atuação no licenciamento e nos estudos de impacto ambiental por parte dos geógrafos, em 
comparação a outros profissionais, a partir da verificação dos EIAs analisados, foram demonstrados quais os capítulos contidos nos EIA-RIMAS, que os geógrafos poderiam elaborar e que o são feito por profissionais com outras formações, de forma qualitativa e quantitativa, caso não seja possível a definição dos capítulos, ao menos, demonstrar-se-á por meio da divisão dos meios: físico, biótico e antrópico.

E também a sistematização de dados recolhidos por meio de dois questionários, os quais acreditamos, fornecerem algumas respostas qualitativas e quantitativas sobre a participação do geógrafo nos EIAs, respondidos por 14 profissionais que atuam em estudos de impacto ambiental, um para geógrafos e outro para outras formações, este número de 14, se deu, simplesmente por terem sido as pessoas que se dispuserem a respondê-los, uma vez que, tantas outras não atenderam a este pedido, por motivos diversos.

\subsection{Atribuições Profissionais Legais do Geógrafo}

Neste item serão expostas as atribuições que, por lei, são outorgadas ao geógrafo, para isto, a principal fonte é a Lei $n^{\circ} 6.664$, de 26 de junho de 1979, a qual disciplina a profissão e dá outras providências.

Art. $3^{\circ}$ - É da competência do Geógrafo o exercício das seguintes atividades e funções a cargo da União, dos Estados dos Territórios e dos Municípios, das entidades autárquicas ou de economia mista e particulares:

I - reconhecimentos, levantamentos, estudos e pesquisas de caráter físicogeográfico, biogeográfico, antropogeográfico e geoeconômico e as realizadas nos campos gerais e especiais da Geografia, que se fizerem necessárias:

a) na delimitação e caracterização de regiões, sub-regiões geográficas naturais e zonas geoeconômicas, para fins de planejamento e organização físico-espacial;

b) no equacionamento e solução, em escala nacional, regional ou local, de problemas atinentes aos recursos naturais do País;

c) na interpretação das condições hidrológicas das bacias fluviais;

d) no zoneamento geo-humano, com vistas aos planejamentos geral e regional;

e) na pesquisa de mercado e intercâmbio comercial em escala regional e interregional;

f) na caracterização ecológica e etológica da paisagem geográfica e problemas conexos;

g) na política de povoamento, migração interna, imigração e colonização de regiões novas ou de revalorização de regiões de velho povoamento;

h) no estudo físico-cultural dos setores geoeconômicos destinados ao planejamento da produção;

i) na estruturação ou reestruturação dos sistemas de circulação; 
j) no estudo e planejamento das bases físicas e geoeconômicas dos núcleos urbanos e rurais;

I) no aproveitamento, desenvolvimento e preservação dos recursos naturais;

$\mathrm{m})$ no levantamento e mapeamento destinados à solução dos problemas regionais;

n) na divisão administrativa da União, dos Estados, dos Territórios e dos Municípios.

Embora a lei que disciplina a profissão do geógrafo, o ampare legalmente a atuar nas diversas áreas expostas acima, cabe uma observação, no sentido de expor, que não só para os geógrafos, mas para qualquer outro profissional, dificilmente uma pessoa sozinha é capaz de atuar em todas as áreas, que sua formação permite. Isso significa dizer que um geógrafo, dificilmente, embora tenha cursado disciplinas em sua graduação que tenha Ihe ensinado aquele tema, irá atuar em todos os ramos que sua ciência estuda; assim é também para os biólogos; geólogos; engenheiros agrônomos, florestais, ambientais, civis; sociólogos; economistas; advogados; gestores ambientais; arquitetos, entre outros que atuem em estudos de impacto ambiental e até em outros setores profissionais.

\subsection{Geografia, Geógrafos e os Estudos de Impacto Ambiental}

Pode-se afirmar que os estudos de impacto ambiental passam a ser exigidos de forma mais contundente no Brasil, efetivamente, na década de 1980, um marco desta prática é a resolução CONAMA nº 01 de 1986, que "dispõe sobre procedimentos relativos ao Estudo de Impacto Ambiental".

Contudo "desde o final da década de 60 o estudo de impacto ambiental constitui um tema conhecido em todo o mundo sob o nome de Environmental Impact Assessment (EIA)." (Ab'Saber, 1998, p. 13)

Prever impactos em relação a um projeto de qualquer tipo, destinado a uma determinada região e a um sítio ou gleba em particular, é uma operação técnicocientifica essencialmente multidisciplinar, de grande importância para os países do terceiro mundo. (Ab'Saber, 1998, p. 27)

A participação de geógrafos em estudos de impacto ambiental não é uma tarefa nova, seja, para propor a resolução de problemas verificados em escala local ou regional, seja para a apresentação dos mesmos ao licenciamento ambiental de 
empreendimentos causadores de modificações no meio ambiente, mais recentemente, sobretudo, a partir do último quarto do século XX no Brasil.

Pode-se afirmar que o reconhecimento, pelos geógrafos, dos desastres ambientais ocorre no pós-guerra e durante a intensificação do processo de colonização européia na África, quando foram adotadas práticas agrícolas de matrizes culturais produtivas dos países colonizadores.

No Brasil, geógrafos como Léo Waibel, Emanuel de Martonne, Orlando Valverde, Aziz Ab'Saber e Manoel Correa de Andrade podem ser considerados os precursores dos estudos das transformações do espaço geográfico pelas diferentes modernizações pela qual passou a agricultura. (Verdum, 2005, p. 92)

A formação do geógrafo, a partir de sua grade curricular, é, por excelência, multidisciplinar, o que garante ao estudante deste curso, o contato com diversos aspectos do conhecimento geográfico e com diversos caminhos a serem seguidos. Evidentemente, essa variedade redunda na diversidade de contato com professores de formações acadêmicas e culturais também bastante ampla.

Esses dados por si só já garantiriam a formação de um aluno e cidadão bastante complexo, com a capacidade de se inserir em uma gama infindável de discussões, ora sobre o urbano, o rural, a morfologia dos lugares, a compreensão do mundo atual e pretérito, ora sobre a geopolítica e a situação econômico-social do global e do local, entre tantas outras capacidades.

O próprio Plano de Metas Acadêmicas do Departamento de Geografia da FFLCHUSP prevê "(...) considerar as diferenças longe de se procurar forjar unanimidades, sem interferir no afloramento da pluralidade dos modos de fazer, pensar e ensinar a Geografia, isto é, as relações da sociedade com a natureza". Reforçando ainda que “(...) o conhecimento só pode ser produzido através do comportamento crítico e do exercício de liberdade e de existência do pleno direito à diferença." (DG, 2003, p. 02)

A dicotomia entre Geografia física e humana revela a possibilidade do entendimento do conjunto da realidade, sob um prisma muito particular, incorporando aos aspectos de apropriação e escolha dos lugares, um significado peculiar.

Cabe também à Geografia, pensar o papel do homem no mundo atual, seus impactos no meio em que vive, sua capacidade transformadora amparada pelo avanço da técnica e da informação em escalas inimagináveis de outrora. 
O domínio do

"novo paradigma socioambiental é um objeto riquíssimo, não mais da Geografia física, da Geografia humana, da Geomorfologia, da Climatologia, entre outros ramos, mas, sim, da Geografia, da abordagem analítico-integradora e sintetizadora de uma Geografia que se preocupa com o "espaço total"” (Ross, 2006, p. 20)

Assim, "para desenvolver a Geografia aplicada, é necessária uma compreensão integrada da realidade socioeconômica sob a perspectiva da dinâmica dos processos de ocupação e das relações econômicas e sociais. "(Ross, 2006, p. 20)

De acordo com o Plano de Metas Acadêmicas do DG, as competências e habilidades desejadas do formando em Geografia são:

- Formar um pensamento crítico, estimulando o desenvolvimento da investigação teórica, científica, técnica e didático-pedagógica em geografia.

- Formar, capacitar e habilitar profissionais para o exercício do magistério, da pesquisa e das atividades técnicas.

- Contribuir para uma atuação consciente na realidade sócio-espacial. (DG, 2003, p. 10)

\subsubsection{Formação Teórica}

A formação teórica do geógrafo é tradicionalmente diferenciada das demais ciências, por se constituir de duas vertentes distintas - a sociedade e a natureza - e pela convergência dessas duas como o próprio objeto de estudo, como pôde ser verificado, por exemplo, nas geografias regionais que se fundamentavam em determinados aspectos físicos e humanos como forma de metodologia de delimitação de uma área a ser estudada.

Já em 1954, Pierre Monbeig chamava a atenção para a importância de se ter geógrafos em equipes multidisciplinares, graças a sua formação teórica e técnica:

Se, precisamente, o geógrafo estuda as relações complexas dos meios naturais e dos grupos humanos em sua localização e em função de sua área espacial, é ele, por excelência, o técnico da organização do espaço. Mas não basta organizar o espaço, é preciso organizá-lo bem. (Monbeig, 1954, p. 71)

Naquela época ele citou, como exemplo, a construção de uma barragem e a participação de diversos profissionais envolvidos num projeto deste porte, no qual o geógrafo tinha um papel importante: 
Os engenheiros que escolhem a localização da barragem levam em conta a altura da queda, o seu débito, a facilidade da construção. Encaram o problema como técnicos de barragem e o que lhes importa é poder construí-la bem, depressa e pelo menor custo. (...) Não se indaga quais serão as conseqüências da barragem sobre o regime do rio a montante, sobre as bacias-vertentes de seus múltiplos pequenos subafluentes, sobre as fontes a eles ligadas, sobre a vegetação que dele depende, as pastagens, as culturas e os homens. Tão pouco se pensou de onde virão os capitais que criarão as indústrias, que deslocamento de mão-de-obra acarretarão, que problemas de urbanismo ou abastecimento daí decorrerão muito em breve, Faltou a isso o geógrafo, cuja profissão é precisamente estudar os múltiplos laços dos inúmeros fenômenos que se relacionam a organização do espaço. (Monbeig, 1954, p. 71,72)

Embora passados 55 anos da publicação deste texto ele ainda possui grande atualidade, quando se pensa em licenciamento ambiental e nos profissionais que elaboram estudos de impacto ambiental, muitos díspares de suas áreas de formação.

Contudo: "Impõe prudente reserva. A Participação dos geógrafos a esse tipo de inquérito não exclui a participação de outros especialistas. O geógrafo não é onisciente e o que lhe cabe é apenas um lugar numa orquestra, mas não a ele toda a orquestra." (Monbeig, 1954, p. 72)

Da mesma maneira que este profissional possui um arcabouço técnico que permite sua atuação em estudos de impacto ambiental, possui também uma formação teórica amparada nas próprias disciplinas presentes no currículo acadêmico, sejam elas de natureza física, biótica ou social, e é desta "totalidade complexa, que a formação específica germina". (DG, 2003, p. 10)

Disciplinas como Climatologia, Cartografia, Geomorfologia, Sensoriamento Remoto, Biogeografia, Pedologia, Hidrografia, Planejamento, Geografia Econômica, Geografia das Indústrias, Urbana, Agrária, Regionais, entre outras, com todo seu aporte teórico proporcionam ao formando, uma possibilidade de investigação própria e uma capacitação bastante relevante ao engajamento deste profissional em equipes multidisciplinares realizadoras dos EIAs. Pode-se afirmar que "a geografia sedimentou um conhecimento na área das ciências humanas, que envolve a relação complexa entre a sociedade e a natureza, através da qual o homem não aparece desvinculado do natural." (DG, 2003, p. 05) 
A importância da formação teórica do geógrafo nos estudos ambientais reside no próprio enriquecimento dos mesmos, que de outra forma, elaborado, por exemplo, por técnicos, não garantiria a sua qualidade em consonância com as exigências dos órgãos licenciadores e em benefício da busca do menor impacto.

E, amparado nas teorias da Geografia, nos conceitos de paisagem, região e espaço geográfico, a observação do geógrafo em relação à realidade estudada, ou a própria área diretamente afetada pelo empreendimento, não consistirá num trabalho meramente técnico, mas sim, num trabalho científico, que traz em seu bojo, teorias científicas, as quais, invariavelmente, trarão uma compreensão distinta de outras.

Como já mencionado no item Base Teórico-Conceitual, conceitos como paisagem e região, trazem em seu bojo, uma possibilidade de investigação relevante aos EIAs, uma vez que é nestas duas categorias que invariavelmente se darão os impactos oriundos da implantação de um novo empreendimento, primeiro na paisagem local (ou área diretamente afetada, como é comum constar nos EIAs), sobretudo na relação com os atributos físicos e bióticos da área, depois na região (ou área de influência direta e indireta), sobretudo nos atributos do meio antrópico, mas também, por vezes, nos aspectos físicos e bióticos.

\subsubsection{Preparo Técnico}

Os estudos de impacto ambiental, apresentados à Secretaria Estadual do Meio Ambiente, CETESB, ou ao IBAMA, por exemplo, nada mais são do que estudos multidisciplinares, elaborados por profissionais com formações diversas.

O preparo técnico do geógrafo reside justamente em sua formação multidisciplinar amparada em técnicas perfeitamente aplicáveis a esses estudos, disciplinas como Biogeografia, Cartografia, Climatologia, Geomorfologia, Hidrografia, Sensoriamento Remoto, Pedologia, Planejamento e Técnicas de Campo e Laboratório, entre outras, além de todo o suporte teórico mencionado no item anterior, também contribuem com técnicas específicas com aplicabilidade bastante pontual em estudos ambientais, sejam técnicas de reconhecimento de vegetação e recolhimento de amostras; medição de precipitação; de cálculos de declividade permitidas para 
determinados usos nos terrenos; medição de vazão em cursos d'água; técnicas de interpretação de fotografias aéreas ou de imagens de satélite, utilização de Sistemas de Informações Geográficas, entre outras.

Este conhecimento multidisciplinar também pode relegar, com propriedade, ao geógrafo, funções como a de coordenador de EIA/RIMAs, por ser esta uma tarefa que exige um conhecimento bastante amplo, que necessita da compreensão dos três meios envolvidos na análise, físico, biótico e antrópico, apreendendo os impactos causados de forma integrada e não fragmentada, como é comum em muitos estudos protocolados na SMA.

Para o professor Jurandyr: "Como o ambiente não é visto apenas como o meio físico e biótico, mas inclui também o sócio-econômico, isso coloca a ciência geográfica como um todo em situação de privilégio frente às demais, nas análises ambientais." (Ross, 1990, p. 19)

O geógrafo é capaz de lidar com técnicas integradoras, como os mapas temáticos, os Sistemas de Informação Geográfica, a análise integrada da realidade com as técnicas próprias de sua formação.

De acordo com o plano de metas acadêmicas do departamento de Geografia:

A formação acadêmica do geógrafo deve prepará-lo teórica e praticamente para atender às necessidades do mercado de trabalho, exigente e competitivo, afim de que não se excluam estes profissionais dos projetos multidisciplinares, por falta de condições operacionais e preparo tecnológico. Neste sentido, também, deve caminhar a formação abrangente e atualizada do profissional geógrafo. (DG, 2003, p. 11)

Esta formação, com as disciplinas de amparo técnico, mencionadas acima, é fundamental para a atuação do geógrafo nos EIAs, servindo de subsídio à sua inserção neste ramo de atividade, inclusive de maneira diferenciada em relação aos outros profissionais, uma vez que:

Em sua formação básica (graduação) o geógrafo adquire conhecimento sobre os diversos componentes dos meios físico, biótico e antrópico, bem como dos processos de interação entre os mesmos na dimensão espaço-temporal, que constituem elementos técnico-científicos fundamentais para a análise do meio ambiente. (Pedroso, 1996) 
A própria inclusão do geógrafo no sistema CONFEA/CREA já denota a possibilidade e preparação técnica deste profissional, sem a qual não haveria sua associação ao grupo das engenharias e arquitetura, onde estão também presentes, geólogos, agrimensores, tecnólogos, etc.

\subsubsection{Formação Crítica}

Uma formação crítica deve refletir a possibilidade da apreensão dos fenômenos de forma analítica.

Trata-se, portanto, da atividade intelectual de separação de elementos do plano discursivo, das narrativas, de modo a tê-los à disposição para investigar quais papéis estão desempenhando no conjunto do que é dito. A filosofia nos diz que a crítica é a análise. "Separar o joio do trigo" é analisar. (Ghiraldelli, 2009)

O perfil desejado do formando em Geografia, de acordo com o Plano de Metas Acadêmicas do Departamento de Geografia, período de 2004-2008, entre outras possibilidades prevê "promover a formação humanística e crítica do aluno de geografia." (DG, 2003, p. 09)

Etimologicamente, a palavra crítica provém do vocábulo grego Kriticós "que julga" assim como do vocábulo Krinum "arte de julgar a bondade, a verdade e a beleza das coisas". (...). Em termos gerais, a critica é uma função hermenêutica sobre determinado tema e que, por sua vez, alude a problemas artísticos e culturais, sociais, etc. Desta feita, a crítica tem um caráter informativo de uma ou mais perspectivas e, sobretudo, de avaliação.

O que é fundamental sublinhar é que a critica não existe em si, esta só é entendida enquanto instrumento ou meio para chegar à verdade - construção hermenêutica. A critica em si não é um juízo (maniqueísta), esta só existe enquanto mediação, ou melhor, tem uma função subordinada em relação ao seu constituinte.

Ao contrario do que se possa pensar, a critica não é um juízo a priori, desta forma, está para além do bem e do mal, a critica só é entendida como uma ferramenta de mediação para alcançar a verdade. (Gonçalves, 2009)

A formação crítica propiciada aos geógrafos advém de vários fatores intrínsecos ao curso, os quais podem ser enumerados da seguinte forma: Em primeiro lugar, pensando-se na USP, por exemplo, deve ser mencionada a localização física do Departamento de Geografia, dentro da FFLCH - Faculdade de Filosofia, Letras e Ciências Humanas, a qual possui um histórico de combatividade e no pensar a sociedade, de onde saíram grandes pensadores brasileiros, que ainda hoje são 
referência em muitos cursos e disciplinas ali ministrados. A Geografia, portanto, ciência humana, inserida na FFLCH, traz em seu bojo, a capacidade crítica de pensar a sociedade e como esta age sobre a natureza.

Em segundo lugar, conforme mencionado anteriormente, a diversidade acadêmica e cultural do professores da Geografia, de onde emanam opiniões e pensamentos bastante diversificados em relação não só as suas disciplinas específicas (dois professores diferentes, lecionando a mesma matéria, podem atingir objetivos particulares e, por vezes distintos), mas mesmo em relação ao como pensar a sociedade, em pensar a Geografia, em pensar a própria estrutura do curso, fazendo com que o aluno se defronte com várias possibilidades intelectuais, enriquecendo em muito, a sua percepção crítica sobre a sociedade e todas suas implicações no mundo contemporâneo.

A Geografia deve ser vista, como uma ciência multidisciplinar, não existindo, portanto uma maneira de fazê-la, mas várias, "no interior desta temos que insistir em mostrá-la cada vez mais como ciência aplicada, socialmente comprometida em suas análises com o bem estar social e na defesa dos cidadãos e do meio ambiente." (Pedroso, 125)

Cabe destacar também que, durante a graduação, o grande número de leituras exigidas, coloca o aluno em contato com autores, igualmente críticos, tanto do modo de produção atual, o qual enriquece o estudo da Geografia com conceitos de maisvalia, apropriação, alienação, luta de classes; como contrários ao tipo de desenvolvimento agrário, concentrador de terras e excludente; ou do tipo de desenvolvimento urbano, privilegiando a circulação de mercadorias em detrimento das pessoas; ou autores que discutem a apropriação dos lugares pelo capital, relegando aos mais pobres, áreas de risco, insalubres, ou impróprias; enfim haveria uma centena de abordagens críticas, das quais, os alunos de Geografia, apreendem durante sua graduação e que modificam, muitas vezes, a maneira de se pensar o mundo e de sua atuação pessoal e profissional dentro da sociedade em que se vive de maneira crítica e particular. 
Não obstante, a ética profissional ${ }^{5}$, pode ser considerada mais um atributo dos formados em Geografia, os quais em sua maioria, não devem se deslumbrar com a atuação nos estudos ambientais, camuflando impactos, mas sim deflagrando-os e propondo sua mitigação de forma substancial, uma vez que muitas medidas propostas nos EIAs podem diminuir bastante o impacto a ser causado pela implantação de um novo empreendimento.

O princípio ético é aquele que concerne aos princípios morais. Num estudo de impacto ambiental há que se considerar esses princípios como balizadores, como algo que de uma forma concreta estabeleça os limites de interesse e de atuação daqueles que, pensando no desenvolvimento como meta final, projetam e constroem grandes empreendimentos.(Verdum; Medeiros, 2002, p. 142)

A conjunção do conteúdo teórico, técnico e crítico, próprios de disciplinas constantes do currículo da Geografia, capacitam este profissional a atuar em questões espaciais, que neste caso referem-se aos estudos ambientais, além de propiciarem uma capacidade de coordenação dos mesmos e uma visão ética a este profissional/ cidadão.

Embora esta dissertação, busque apresentar novos e antigos caminhos de atuação para os geógrafos, neste ramo de atividade profissional - o licenciamento ambiental - podendo amparar e direcionar estes profissionais e até servindo de motivação e conhecimento de suas capacidades, há também alguns aspectos relacionados a este campo de trabalho, que com a visão crítica adquirida não só no curso superior, mas também nesses anos de atuação, que devem ser mencionados.

Os EIAs apresentados para a análise, por exemplo, da SMA, são elaborados a partir de roteiros pré-estabelecidos pelo próprio órgão ambiental (roteiro de elaboração de RAPs) e por Termos de Referência (para nortear a capitulação de EIA-RIMAs) com a função de orientar os consultores, sobre os itens que devem ser abordados para a plena avaliação dos impactos daquele determinado empreendimento. As consultorias ambientais, quando contratam o profissional para a elaboração de um determinado relatório que irá fazer parte do EIA total, espera que ele apresente seu

\footnotetext{
${ }^{5}$ Em 10 anos de atuação direta no CREA/SP, representando os geógrafos, nunca houve um processo ético incidindo sobre um profissional com esta formação. (Informação Verbal fornecida pelo Prof. Dr. Wagner Costa Ribeiro, São Paulo, março de 2009.)
} 
estudo, exatamente, como pedido pela SMA e que de fato seria mais correto, portanto, inibindo algumas ousadias e tentativas de se escapar da receita préestabelecida.

Outro aspecto que merece ser focado se refere à corrupção existente neste ramo de atividade e que vez ou outra é deflagrada nos meio de comunicação, esta corrupção geralmente se encontra nos altos escalões de tomada de decisões na emissão das licenças ambientais e não deve ser vista como algo generalizado, mas que ocorre sim, não só no âmbito estadual, mas também na esfera municipal e federal, atuar de forma ética deve ser sempre um atributo vinculado aos profissionais desta área.

Os estudos de impacto ambiental acompanhados de audiência pública, instituídos pelo CONAMA, foram concebidos como política preventiva. Porém, a prática nega sua concepção.

"A ampla maioria dos EIAs são orientados para justificar a implantação do projeto em sua forma original, e não para abrir um processo de negociação, têm uma retórica destinada a convencer que foram tomadas todas as providências possíveis para proteger o meio ambiente. Estudos deste tipo não permitem que a avaliação do impacto seja (como deveria ser) um subsídio prévio (ex-ante) à definição final do projeto, e não uma rotina burocrática onde a realização ou não da audiência pública faz pouca diferença." (Corbucci, 2003, p. 83)

A "audiência pública, como fórum de participação, também é descaracterizada devido ao poderio dos recursos técnico e político dos empreendedores, frente à manipulação das populações atingidas e ao desaparelhamento e despreparo da maioria dos órgãos ambientais dos governos e das ONGs." (Corbucci, 2003, p. 83)

Pode-se afirmar que, "a tendência tem sido para que os EIA-RIMAs no Brasil sirvam mais como instrumentos de justificação de decisões já tomadas, do que como instante de abertura de um processo de negociação. Como salienta Héctor Leis (1997, apud Cavalcanti, 2004, p. 05), eles "são orientados para justificar a implantação dos projetos em sua forma original" e seus eventuais impactos ambientais, mostrados "como contrapartida e condição inevitável" para que se desfrute dos benefícios trazidos pelos projetos."

Ainda assim, numa conclusão dúbia, é necessário afirmar que com todas os problemas enfrentados para a análise, aprovação, audiências públicas, etc., é muito melhor que haja esses estudos, do que ocorra a implantação de empreendimentos 
sem quaisquer estudos prévios, como ainda se verifica em lugares mais afastados dos grandes centros. Com os EIAs, muitas medidas de prevenção sugeridas nos relatórios individuais e no seu cômputo geral acabam por ser realizadas, trazendo, muitas vezes, impactos bem menores do que os que poderiam ocorrer.

Cabe ao administrador público avaliar os elementos dispostos nos EIAs e as considerações feitas na audiência, que podem ser conflitantes ou contraditórias, e acatá-las ou refutá-las, fundamentando sua decisão.

Outro problema reside em, conforme já presenciado, sobretudo nos municípios menores, e em empreendimentos de grande impacto ambiental, mas sem a cobertura da mídia, portanto, desconhecidos pela imensa maioria da população indireta e diretamente atingida, empreendedores que se amparam no discurso da criação de empregos, que sempre resulta em apoio aos mesmos, relegando aos impactos uma relevância menor, sejam eles situados em Áreas de Proteção Ambiental ou impróprias para determinadas atividades.

Muitos fatores podem levar ao descrédito neste campo profissional, seja secretários municipais de meio ambiente, ou prefeitos, donos de imobiliária e de terras, aprovando determinados empreendimentos que valorizarão suas posses, seja vereadores defendendo o EIA em audiência pública, quando se sabe que eles nem leram o mesmo, ou a aprovação de empreendimentos em áreas de preservação permanente em que os empreendedores drenam e "escondem nascentes" para ter ganhos de áreas, ou projetos "aprovados" antes mesmo da apresentação do EIA, entre outras situações.

Cabe ao profissional, geógrafo ou não, se distanciar, sempre que perceber, de consultorias ambientais que adotam essas práticas excusas. E se fizer parte da análise dos EIAs (trabalhando na SMA, por exemplo), desconfiar de "EIAs relâmpago", que entram na análise na frente de todos que já estavam sendo analisados, bem como, quando elaborar um estudo e tiver convicção dos impactos causados pelo empreendimento, desconfiar dos coordenadores dos EIAs que queiram mascarar tais impactos. 


\section{RELATÓRIOS PASSíVEIS DE SEREM ELABORADOS PELO GEÓGRAFO}

Abordados os aspectos legais, a base teórico-conceitual, a formação teórica, técnica e crítica do geógrafo, seguem agora exemplos de alguns relatórios constantes nos estudos de impacto ambiental, passíveis de serem executados por este profissional, os quais são protocolados e analisados na instância municipal, estadual ou federal; em algumas secretarias municipais de meio ambiente (somente as que possuem quadro técnico para tal); na Secretaria Estadual de Meio Ambiente ou CETESB; e no IBAMA, respectivamente.

A compartimentação (em relatórios individuais, tal como são apresentados nos diagnósticos internos dos EIAs) servirá para demonstrar quais dos capítulos se enquadram em trabalhos passíveis de serem realizados pelos geógrafos, demonstrando as potencialidades de atuação deste profissional, a partir, portanto, da síntese de cada um.

É importante informar que os relatórios são divididos em duas etapas: a primeira representa o diagnóstico da situação atual da área de estudo e de seu entorno; e a segunda, o prognóstico, que considera os impactos que serão causados pela introdução do novo empreendimento, bem como quando esses forem negativos, a proposição de medidas mitigadoras e compensatórias. Somente como exercício, a seguir apresentar-se-á, principalmente, os diagnósticos, uma vez que ele é praticamente igual para todos os empreendimentos, diferentemente do prognóstico de impactos, específico e diferente, geralmente, para cada atividade e para cada localidade.

Pode-se afirmar que:

"Dois empreendimentos idênticos localizados em ambientes diferentes resultarão em diferentes impactos ambientais. Da mesma forma, num mesmo local, dois projetos distintos poderão ocasionar impactos ambientais bem diferentes." (Sánchez, 2008, p. 169)

A implantação de uma indústria, por exemplo, em um parque industrial, acarretaria em impactos diferenciados, caso o mesmo empreendimento estivesse previsto para uma área rural; da mesma forma, um aterro sanitário ou uma linha de transmissão 
de energia, trariam impactos distintos, quando implantados, hipoteticamente em uma mesma paisagem ou região.

"Por outro lado, sabe-se que os impactos e os riscos ambientais não são percebidos da mesma forma por pessoas ou grupos sociais diferentes." (Sánchez, 2008, p. 169) Cabe ao profissional e à equipe multidisciplinar envolvida na elaboração do EIA, discutir, quais impactos deverão merecer uma maior atenção para o empreendimento que estiver em pauta naquela região e naquele estudo.

\subsection{Uso e Ocupação do Solo}

Neste relatório, especificamente, busca-se demonstrar as características atuais da área de estudo e de seu entorno, no que se refere às categorias de paisagem ali existentes, evidenciando que tipo de ocupação tem sido dada à terra naquela porção territorial do município em que se localizará o empreendimento a ser licenciado.

Os procedimentos utilizados para a definição do uso e ocupação do solo redundam na demarcação de unidades espaciais existentes na gleba e em seu entorno, conformando-se em definições das categorias de análise. Esta demarcação pode seguir o padrão adotado pelos órgãos institucionais oficiais (IBGE, ou EMPLASA, por exemplo), ou pode-se adotar uma delimitação particular. As categorias de análise são definidas posteriormente ao levantamento de campo, bem como pela interpretação de aerofotografias, imagens de satélite, mapas e cartas.

Esses procedimentos visam, além de um relatório descritivo, à obtenção final de uma padronização que permita, a partir de um mapa, geralmente, em escala 1:10.000, a compreensão das unidades espaciais envolvidas, ou seja, as próprias áreas de influência do empreendimento, Área de Influência Indireta (pode ser uma delimitação territorial, estado ou município, ou até mesmo uma região, de acordo com critérios específicos para cada empreendimento), Direta (região delimitada por aspectos específicos) e Área Diretamente Afetada (paisagem local), respectivamente (AII, AID e ADA). 
Os dados obtidos em campo e os materiais cartográficos são analisados de forma integrada, objetivando a confecção do mapa de uso e ocupação do solo, bem como a descrição das categorias de uso.

(...) a descrição das formas de uso do solo, essencial para apreender-se o contexto em que se insere a proposta analisada. Para fins de descrição estrita das modalidades de uso e ocupação pela sociedade, a legenda de um mapa de uso do solo poderá apresentar classes como "área urbana", "culturas temporárias", "pastagens", "culturas permanentes" e "vegetação nativa". (Sánchez, 2008, p. 228)

Para a identificação das categorias de análise, considera-se uma área ideal, onde as características principais possam ser representadas territorialmente. Assim, algumas classes de interpretação comporão o mapa de uso e ocupação do solo e o texto descritivo, tais como: áreas de mata nativa, campos antrópicos, chácaras, áreas urbanizadas, equipamentos urbanos, entre outras, dependendo da localização do empreendimento.

Este relatório compreende:

Um tema básico para planejamento ambiental, porque retrata as atividades humanas que podem significar pressão e impacto sobre os elementos naturais. É uma ponte essencial para a análise de fontes de poluição e um elo importante de ligação entre as informações dos meios biofísico e socioeconômico. (Santos, 2004, p. 97)

Neste relatório também, pelo geógrafo, são contemplados, como mencionado, os conceitos de paisagem e de região, devendo ser adaptados de acordo com o local e a especificidade de cada estudo, enquadrando o lugar analisado da melhor forma que convier à sua observação.

- As disciplinas do curso de Geografia, que preparam o profissional para este relatório são, sobretudo, aquelas do eixo cartográfico, como a Cartografia Temática, que contribui na elaboração do mapa de uso do solo, abordando as categorias acima mencionadas (mata nativa, áreas urbanizadas etc.); de igual importância são as disciplinas de Sensoriamento Remoto, Aerofotogeografia e Cartografia Ambiental, todas que, de certa forma, auxiliam na interpretação das fotografias aéreas e das imagens de satélite, que posteriormente permitem a elaboração do mapeamento e descrição deste relatório, além de Teoria Geográfica da Paisagem, que traz um 
subsídio teórico na compreensão das escalas de análise da paisagem; e Teoria da Região e Regionalização, que permite a apreensão da abordagem deste conceito, igualmente com seu arcabouço teórico, permitindo o recorte necessário a cada relatório.

Indiretamente, outras disciplinas, subsidiam os geógrafos na elaboração deste relatório, como por exemplo, Biogeografia, que mostra tipos de vegetação; Hidrografia, e a delimitação de bacias hidrográficas; além de diversas outras que, de alguma forma, contribuem para o reconhecimento e formação das categorias de análise que comporão o estudo e o respectivo mapa, tais como Geografia Urbana, Geografia Agrária, ou Geomorfologia.

Atualmente, há também disciplinas que contribuem com 0 aprendizado de ferramentas ligadas a informática: Microinformática Instrumental em Geografia, Introdução aos Sistemas de Informações Geográficas, que podem se apresentar com outras nomenclaturas nas diversas Instituições de Ensino Superior e que se associaram na contribuição da elaboração do(s) mapa(s).

- Os artigos da Lei n 6.664, a qual disciplina a profissão de geógrafo, que amparam legalmente a elaboração deste relatório são, sobretudo, estes listados na seqüência:

a) na delimitação e caracterização de regiões, sub-regiões geográficas naturais e zonas geoeconômicas, para fins de planejamento e organização físico-espacial; d) no zoneamento geo-humano, com vistas aos planejamentos geral e regional;

f) na caracterização ecológica e etológica da paisagem geográfica e problemas conexos;

j) no estudo e planejamento das bases físicas e geoeconômicas dos núcleos urbanos e rurais;

m) no levantamento e mapeamento destinados à solução dos problemas regionais;

- Os conceitos e as habilidades técnicas que se relacionam com as disciplinas de apoio acima mencionadas são, sobretudo, os de região e paisagem, na delimitação das áreas de influência do empreendimento, bem como, em alguns casos, o conceito de território, quando da abordagem municipal, por exemplo. Nos aspectos técnicos, apóiam-se nas ferramentas de microinformática, sensoriamento remoto e cartografia, com o aprendizado de programas específicos, como o Spring e o llwis, atualmente utilizados em algumas disciplinas. Para o reconhecimento de campo, as 
ferramentas da disciplina Técnicas de Campo e Laboratório também contribuem para a realização deste relatório, assim como o aprendizado nos trabalhos de campo do curso de Geografia como um todo, cada disciplina contribuindo de forma direta e indireta para a apreensão da realidade posta.

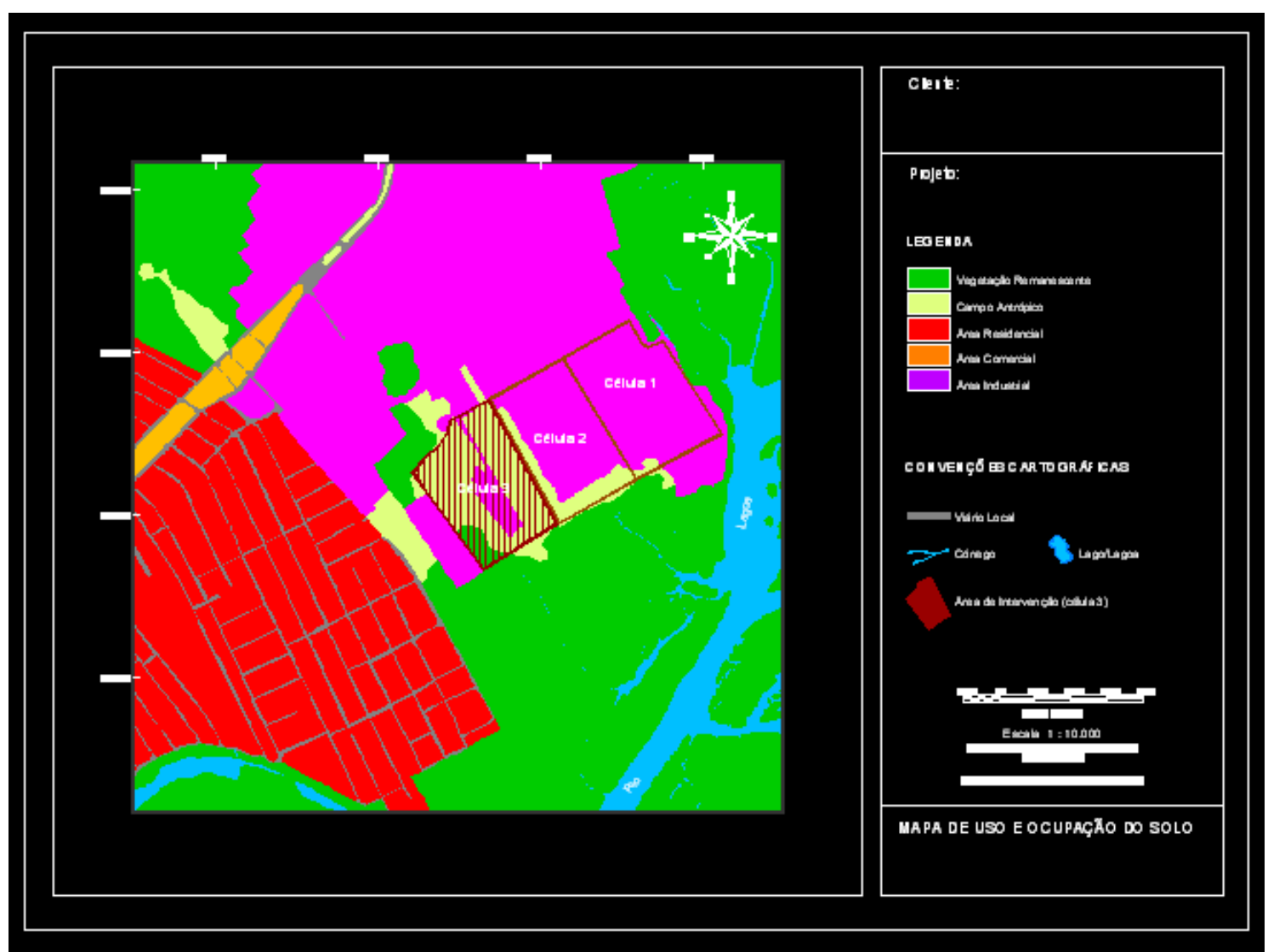

Mapa 3.1-1: Exemplo de um Mapa de Uso e Ocupação do Solo elaborado para um trabalho realizado por este autor.

Propositadamente, os dados encontram-se ilegíveis, por se tratar de área em licenciamento atualmente, portanto, ainda confidencial. Em lilás, área da indústria que licencia sua expansão; em verde, matas remanescentes; em vermelho, áreas urbanizadas; azul, hidrografia local; e em amarelo, campos antrópicos.

\subsection{Socioeconomia}

Trata basicamente dos aspectos relacionados à população que será atingida pelo impacto do empreendimento pleiteado para o local estudado, abrangendo dados 
demográficos e pesquisas de campo, como por exemplo, nível escolar, de saúde ou de emprego e renda.

A definição da população a ser afetada pelo novo empreendimento deve ser amparada em critérios formulados pelo executor do trabalho, ou seja, a área de influência direta ou indiretamente afetada irá ser constituída a partir da experiência do geógrafo envolvido na análise e em sua formação acadêmica, que o alicerçará nesta tarefa. Para o geógrafo, alguns procedimentos ou até métodos podem ser utilizados nesta delimitação, como por exemplo, o conceito de região estabelecida por meio de uma reunião de atributos do lugar, tais como grau de urbanização, remanescentes vegetais nativos, áreas de reflorestamento, porções predominantemente residenciais ou campos agricultáveis, para os quais cada categoria pode redundar numa especificidade a ser estudada e assim a avaliação do impacto será mais bem formulada.

Embora a população envolvida na região em que se implantará o empreendimento seja exaustivamente estudada com dados censitários, por exemplo, muitas vezes, falta uma análise pormenorizada obtida por meio de trabalho de campo para se apreender os reais impactos causados pela adição de uma nova alteração local ou regional.

(...) considerar o homem como um simples objeto que pode ser deslocado, mudado, transferido, com relativa facilidade é pensar o homem fora da natureza.

O homem é um ser social, mas que está inserido num conjunto maior no qual ele é uma engrenagem, portanto, não pode e não deve ser visto, compreendido, ou entendido fora desta grande máquina que é a natureza. (Medeiros, 2002, p. 126)

Uma metodologia sugerida pelo prof. Ab'Saber e útil em estudos socioeconômicos, refere-se à utilização do conceito de espaço total como forma de se apreender os impactos causados por um empreendimento não só na gleba a ser impactada pelo mesmo, mas sobretudo, no entorno desta área.

A análise do sítio ou local de implantação tem uma certa importância. Entretanto, é a área do entorno do projeto que mais importa em termos de curto, médio e longo prazo. (...) O espaço total é o arranjo e o perfil adquiridos por uma determinada área em função da organização humana que lhe foi imposta ao longo dos tempos. (...) Na realidade, o espaço total é que inclui todo o mosaico dos componentes introduzidos pelo homem - ao longo da história - na paisagem 
de uma área considerada participante de um determinado território. (Ab'Saber, 1998, p. 30)

Já, a interpretação de aerofotografias constitui-se num trabalho preliminar, no qual o geógrafo se depara com a área a ser estudada e com a complexidade da análise a partir da verificação a priori dos caminhos a serem percorridos em campo, como forma de detectar os lugares em que o impacto pode ser mais relevante.

Este relatório "é importante, tanto em sítio urbano quanto rural, porque conduz à elaboração de alternativas de ação sob diferentes contextos, sempre tendo em vista a proteção do potencial econômico da terra ou do próprio sistema de produção." (Santos, 2004, p. 103). Bem como, pode fornecer as diretrizes de implantação do empreendimento com intuito de minimizar seu impacto na população atingida pelo mesmo.

Em planejamento ambiental, considerar os aspectos socioeconômicos é significativamente importante, pois com eles se pode nortear os impactos positivos ou negativos relacionados com a introdução de um novo empreendimento, bem como sua (re)adequação ao município ou a região pré-estabelecida pelo profissional, que irá receber esta implantação.

O diagnóstico socioeconômico amparado no trabalho de campo e muitas vezes em entrevistas e conversas com moradores do entorno do novo empreendimento, pode relegar à definição dos impactos e proposição de medidas compensatórias o aspecto mais importante do EIA. Como exemplo, imagine-se um empreendimento que necessite realocar famílias para sua implantação; imagine que se estas famílias subsistam a partir de uma determinada renda só obtida por um produto daquela região, transferir estas famílias para um local em que não haja este produto seria modificar a cultura desta comunidade. O conceito de lugar fundamenta esta explicação: a existência dessas pessoas está relacionada ao lugar, ali está sua história, sua afetividade, tendo-se que dali se mudar, o sentido do lugar, para elas, se desfaz. Portanto, trata-se também de um trabalho de muita responsabilidade, acuidade crítica e ética profissional.

- As disciplinas do curso de Geografia, que preparam o profissional para este relatório são: Geografia Econômica, Geografia dos Recursos Naturais, 
Planejamento, Geografia Política, Geografia Urbana, Agrária e em alguns casos, as Geografias regionais (Sul, Sudeste, Nordeste, Amazônia), além daquelas do eixo cartográfico: Cartografia Temática, Sensoriamento Remoto, Aerofotogeografia e Cartografia Ambiental, todas que de certa forma auxiliam na interpretação das fotografias aéreas e das imagens de satélite, que posteriormente permitem a verificação em campo das áreas afetadas pelo empreendimento (urbanizadas, rurais, preservadas, intensamente antropizadas etc.). A Teoria Geográfica da Paisagem traz um subsídio teórico na compreensão das escalas de análise da paisagem e Teoria da Região e Regionalização permite a apreensão da abordagem deste conceito, igualmente com seu arcabouço teórico, permitindo o recorte necessário deste relatório (região como recorte municipal ou distrital, por exemplo).

Outras disciplinas também contribuem na elaboração deste relatório, como por exemplo, Regionalização do Espaço Brasileiro, na qual se busca entender o processo de formação econômica e social dos estados brasileiros e o consequente estágio atual de desenvolvimento relacionado com a formação dos mesmos, ora nos aspectos históricos, ora sob o enfoque geográfico (processo de acumulação de riquezas, localização dos sítios urbanos, concentração industrial, áreas agrícolas etc.), bem com a disciplina de Geografia da População.

- Os artigos da Lei $n^{\circ} 6.664$, que disciplina a profissão de geógrafo e amparam legalmente a elaboração deste relatório são, sobretudo, estes listados na seqüência:

a) na delimitação e caracterização de regiões, sub-regiões geográficas naturais e zonas geoeconômicas, para fins de planejamento e organização físico-espacial;

d) no zoneamento geo-humano, com vistas aos planejamentos geral e regional;

e) na pesquisa de mercado e intercâmbio comercial em escala regional e interregional;

f) na caracterização ecológica e etológica da paisagem geográfica e problemas conexos;

g) na política de povoamento, migração interna, imigração e colonização de regiões novas ou de revalorização de regiões de velho povoamento;

h) no estudo físico-cultural dos setores geoeconômicos destinados ao planejamento da produção;

i) na estruturação ou reestruturação dos sistemas de circulação;

j) no estudo e planejamento das bases físicas e geoeconômicas dos núcleos urbanos e rurais; 
- Os conceitos e as habilidades técnicas que se relacionam com as disciplinas de apoio acima mencionadas são, sobretudo, os de região e paisagem, na delimitação das áreas de influência do empreendimento, com, por exemplo, uma região portuária, com todo o aporte de equipamentos públicos e privados inerentes a esta atividade. Nos aspectos técnicos, também as ferramentas de microinformática e fotointerpretação, permitem reconhecer a área de estudo e sua região.

Para o trabalho de campo, com vistas a compreender a população atingida pelo novo empreendimento, conceitos como apropriação dos lugares pelo capital se mostram bastante úteis na identificação, por exemplo, de vetores de expansão urbana, expropriação de população de baixa renda, para empreendimentos em locais, ora valorizados, para determinada função; a localização geográfica de determinados empreendimentos em relação ao seu mercado consumidor, recursos naturais $x$ mercado alvo; alguns empreendimentos se estabelecem preferencialmente onde possa haver mão-de-obra, por um lado, e até onde possa ser transportado (por exemplo, mineração, se estiverem muito longe de seu mercado consumidor, não há retorno financeiro, a não ser que o minério em pauta, possua um valor de mercado que compense os custos de transporte e logística), a apreensão dos lugares é importante neste campo profissional.

A seguir, dois dados da área de influência indireta, neste exemplo, o município de São Paulo, determinado como a região impactada indiretamente pelo empreendimento licenciado por este autor, no ano de 2007. Dados demográficos e ocupação dos trabalhadores são comumente exigidos para a compreensão do perfil municipal em que se encontra o empreendimento. 


\begin{tabular}{|c|c|c|c|}
\hline \multicolumn{7}{|c|}{$\begin{array}{r}\text { Densidade Demográfica Município de São Paulo } \\
\mathbf{1 9 5 0} \mathbf{2 0 0 0}\end{array}$} \\
\hline Anos & População Total & Área $\left(\mathrm{km}^{2}\right)$ & $\begin{array}{c}\text { Densidade } \\
\text { hab/km }\end{array}$ \\
\hline 1950 & 2.198 .096 & 1.624 & 1.354 \\
\hline 1960 & 3.666 .701 & 1.587 & 2.310 \\
\hline 1970 & 5.924 .615 & 1.509 & 3.926 \\
\hline 1980 & 8.493 .226 & 1.509 & 5.628 \\
\hline 1991 & 9.646 .185 & 1.509 & 6.392 \\
\hline 2000 & 10.434 .252 & 1.509 & 6.915 \\
\hline
\end{tabular}

Tabela 3.2-1: Densidade Demográfica Município de São Paulo, 1950-2000. Fonte: PMSP, 2004.

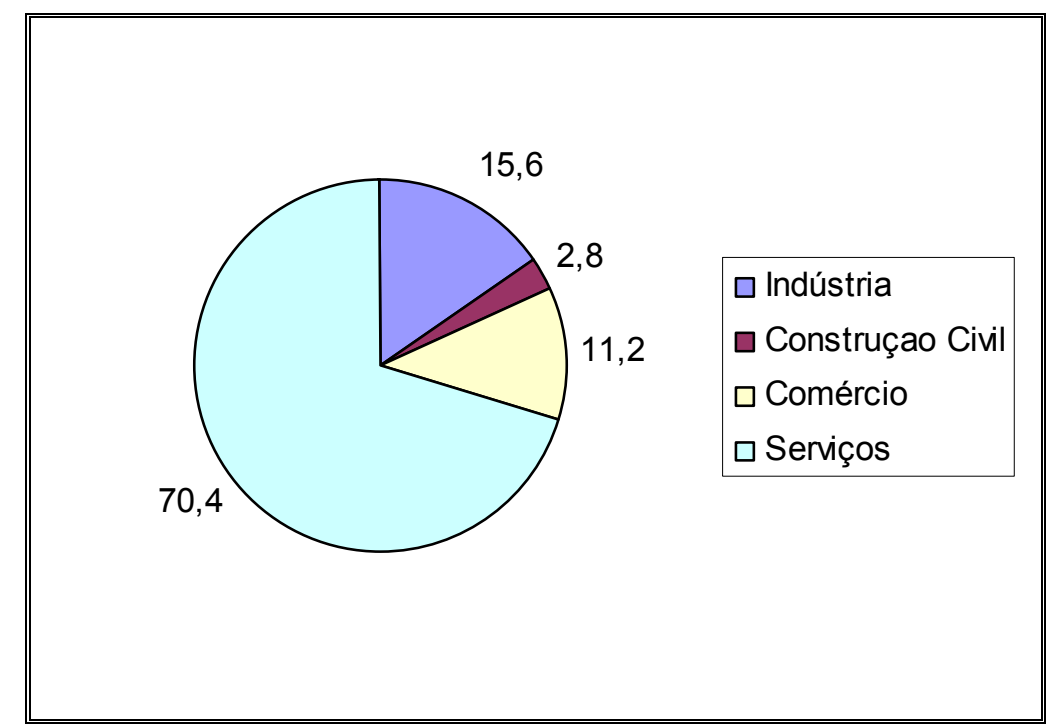

Figura 3.2-1: Ocupação dos trabalhadores do município de São Paulo, percentual por setores de atividade. Fonte: PMSP, 2004.

É importante que as tabelas e figuras a serem apresentadas possuam relevância para a apreensão dos impactos causados pelo novo empreendimento, pois, muitos EIAs são carregados de informações supérfluas, que não contribuem para o adequado entendimento da realidade posta.

\subsection{Sistema Viário}


Este relatório, presente em muitos estudos de impacto ambiental, visa demonstrar, por meio de um diagnóstico local e regional, a infra-estrutura viária existente e sua capacidade ou não de receber um novo empreendimento, que muitas vezes, pode ocasionar em impactos muito significativos, prejudicando toda a movimentação de pessoas e mercadorias.

Movimento, comunicação e viagens são partes integrais do cotidiano. Todos esses conceitos são básicos para o entendimento do tráfego em um determinado sistema viário, independente dos diferentes tipos de paisagem ou mesmo do sentido de lugar. Em um quadro geral, pode-se entender que o sistema viário estabelece relação entre áreas e, portanto, é essencial para as atuais práticas sociais e econômicas.

As cidades atuais têm acompanhado mudanças no que dizem respeito às normas que a regem e, por isso mesmo, essas mudanças estabeleceram uma nova ordem no tipo de uso e ocupação do solo. As relações espaciais e conexões entre áreas são frequentemente refletidas no caráter das facilidades dos transportes e no fluxo do trânsito. (Hurst, 1974).

Essas modificações no uso e ocupação do solo, da qual o sistema viário faz parte, são decorrentes dos investimentos tanto públicos (na esfera do poder público), como privados (investimentos imobiliários, comerciais etc.). A estrutura física e a forma de utilização do sistema viário refletem diretamente esta dinâmica urbana (Storper, 1990). Como não pode deixar de ser, as vias da rede viária estrutural constituem o suporte para o fluxo de veículos que se relacionam diretamente com a circulação e o transporte urbano. Por meio da rede viária é possível realizar deslocamentos intra e inter (urbanos) que atendam as necessidades sociais e econômicas.

A implantação de novos empreendimentos, de algum modo, altera o perfil do tráfego na malha viária de uma dada região com suas características próprias préestabelecidas. "Dessa maneira, uma nova atividade próxima as principais vias estruturais, pode potencializar o fluxo e o tráfego nas redes de circulação, devido a viagens adicionais, fruto da nova atividade" (Bullock, 1998). 
A localização da área desses novos empreendimentos, dentro de uma cidade, é resultado de uma série complexa de eventos, que podem ser entendidos somente em seu relacionamento com um quadro geral do sistema urbano e, quais particularidades uma cidade ou uma região possuem, seja em infra-estrutura, situação e localização (Garrison, 1959).

A escolha das vias a serem estudadas obedece à lógica ditada pela Geografia urbana, essas vias, na maioria das vezes, estão representadas no Plano Diretor Físico do Município em estudo, com relação à sua mobilidade e a classificação do sistema viário em questão.

- As disciplinas do curso de Geografia, que preparam o profissional para este relatório são, sobretudo, Geografia Econômica, Urbana, Agrária e Geografia do Estado de São Paulo (para empreendimentos dentro deste território administrativo), além daquelas do eixo cartográfico: Cartografia Temática, que contribui para a confecção dos mapas viários, de igual importância, são as disciplinas de Sensoriamento Remoto, Aerofotogeografia e Cartografia Ambiental, todas que de certa forma auxiliam na interpretação das fotografias aéreas e das imagens de satélite, que posteriormente permitem a elaboração do mapeamento e descrição do sistema viário envolvido na análise, além de Teoria da Região, que permite a verificação do sistema viário através do critério regional: regiões densamente antropizadas, possuem igualmente um sistema viário complexo, podendo ser este um recorte utilizado.

- O artigo da Lei $n^{\circ} 6.664$, a qual disciplina a profissão de geógrafo, que ampara legalmente a elaboração deste relatório é, sobretudo, este listado abaixo:

i) na estruturação ou reestruturação dos sistemas de circulação;

- Os conceitos e as habilidades técnicas que se relacionam com as disciplinas de apoio acima mencionadas são, sobretudo, os de região e paisagem, na delimitação das áreas de influência do empreendimento. Nos aspectos técnicos, as ferramentas de microinformática, sensoriamento remoto e cartografia, além do aprendizado de programas específicos, como o Spring e o llwis, atualmente utilizados em algumas disciplinas se fazem de grande importância. Para o reconhecimento de campo, as 
ferramentas da disciplina Técnicas de Campo e Laboratório, também contribuem para a realização deste relatório, assim como o aprendizado nos trabalhos de campo do curso de Geografia como um todo, cada disciplina contribuindo de forma direta e indireta para a apreensão do sistema viário em análise.

Conceitos de fixos e de fluxos trabalhados por Milton Santos, também apresentam importância neste relatório, uma vez que a localização dos fixos (indústrias, galpões de armazenamento de produtos e mercadorias) está diretamente relacionada com os fluxos, que devem facilitar a implementação dos fixos, neste caso até mesmo podendo considerar o empreendimento, ora em licenciamento.

A escolha dos lugares é, inclusive, alvo de um item constante nos EIAs, denominado: "Alternativas Técnicas e Locacionais", de modo a justificar o impacto de um novo empreendimento naquele local escolhido. Os fluxos serão facilitados por esta localização? Os fixos do entorno ajudarão àquela instalação (fornecedores de produtos e serviços necessários ao pleno funcionamento desta nova atividade)?

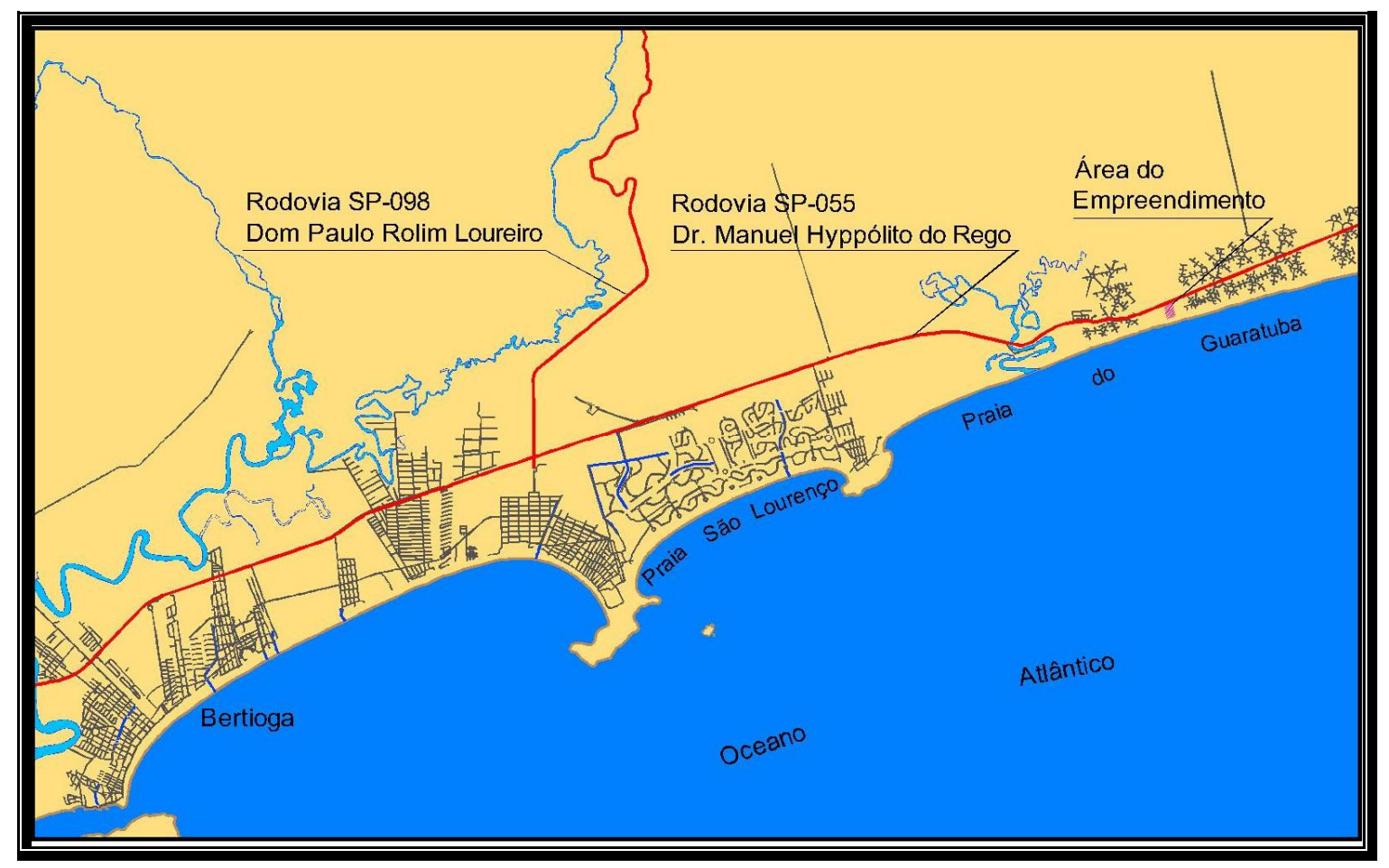

Mapa 3.3-1: Sistema viário regional, exemplo de um mapa constante num licenciamento de área localizada no litoral paulista, após a descrição e compreensão do sistema viário regional, ilustra-se com o mapa, como forma de se visualizar as informações elencadas. (Situação sem escala). 
Por se tratar de um licenciamento ambiental menos complexo (não era um EIARIMA), no qual nem era exigida a apresentação de mapa viário, o mesmo foi elaborado sem escala, apenas para se espacializar a informação textual, podendo até, noutra oportunidade, ser nomeado como "croqui".

\subsection{Resíduos Sólidos}

Este relatório, algumas vezes presente em estudos ambientais, especificamente de novos loteamentos residenciais ou comercias, bem como em distritos industriais e alguns outros empreendimentos que possam acarretar em grandes gerações de resíduos sólidos, visa demonstrar a capacidade de adaptação do município a ser impactado pela implantação de uma nova instalação em seu território.

Não há co-responsabilidade da população pela produção do lixo. A maioria das pessoas coloca-se no papel de cobrar a administração pública pela melhoria do sistema e se compromete apenas em colocar os resíduos para a coleta pública recolher. Também não há poucas responsabilidades das empresas produtoras dessas embalagens no destino final das mesmas. (Lopes, 2006, p. 101)

É neste estudo que, muitas vezes, ficam estabelecidas parcerias entre o poder público e a iniciativa privada no que concerne à destinação de resíduos gerados, pois algumas vezes o poder público não encontra condições de, sozinho, arcar com uma nova carga de resíduos que, por vezes, para aquele município se constituiria em perda de vida útil de seu aterro, ou gastos excessivos para as receitas, fazendo com que as novas instalações reduzam a geração de lixo, a partir de medidas de reciclagem e destinação, por exemplo.

Cabe ressaltar que,

A questão dos resíduos sólidos é emblemática (...) não é possível encará-la apenas como um problema econômico ou ambiental. (...) é também uma questão cultural, social, de saúde e de educação e as alternativas precisam ser analisadas em todas essas dimensões. Não basta, por exemplo, fazer um plano de coleta seletiva sem pensar no mercado da reciclagem na região e, muito menos, sem envolver a comunidade. Também não é possível organizar um bom sistema de coleta e dissipação inadequada ou, ainda, organizar um aterro sanitário e não pensar na redução de resíduos. (Lopes, 2006, p. 52)

Com este relatório, demonstra-se também, a demanda gerada pelo novo empreendimento e a capacidade de destinação do município que receberá a nova 
carga de materiais oriunda da nova atividade, de forma quantitativa, para cálculos de impacto.

- Não há uma disciplina do curso de Geografia, que trate diretamente deste assunto, mas em muitas aulas este é trabalhado por professores, como por exemplo, em Geografia Urbana e a temática de qualidade de vida e apropriação dos lugares, em que moradores de baixa renda se localizam em áreas insalubres, próximas a lixões e aterros sanitários, inclusive, tirando dali seu sustento; Geografia dos Recursos Naturais, analisando-se os resíduos sólidos com um recurso não natural orgânico; ou sua termo-valorização. Em Geomorfologia I, também foi trabalhada esta questão, de moradias em áreas impróprias, como vertentes, áreas de inundação natural e áreas de disposição de inertes, em que não há uma sustentação para edificações, acarretando em problemas para seus moradores. Em Pedologia, sob os aspectos de infiltração do chorume no solo.

Muitos alunos, na disciplina de Iniciação a Pesquisa, trabalham com a temática dos resíduos sólidos urbanos, portanto, deparam-se com esta questão e assim, podem trabalhar com ela em Estudos de Impacto Ambiental.

- Os artigos da Lei n 6.664, a qual disciplina a profissão de geógrafo, que amparam legalmente a elaboração deste relatório são, sobretudo, estes listados na seqüência:

a) na delimitação e caracterização de regiões, sub-regiões geográficas naturais e zonas geoeconômicas, para fins de planejamento e organização físico-espacial; d) no zoneamento geo-humano, com vistas aos planejamentos geral e regional; f) na caracterização ecológica e etológica da paisagem geográfica e problemas conexos;

I) no aproveitamento, desenvolvimento e preservação dos recursos naturais;

m) no levantamento e mapeamento destinados à solução dos problemas regionais;

- Aqui também, os conceitos e as habilidades técnicas que se relacionam com as disciplinas de apoio acima mencionadas são, sobretudo, os de região e paisagem, comuns a maioria dos relatórios constantes nos EIAs, visto que sempre haverá impacto local (paisagem) e nas áreas de influência Direta e Indireta (região).

Nos aspectos técnicos, os trabalhos de campo de todas as disciplinas e especialmente, de Geomorfologia, Pedologia e Biogeografia subsidiam a compreensão de aspectos naturais que se relacionam diretamente, com a escolha 
de um lugar a que se destine resíduos sólidos urbanos domiciliares, assim evidencia-se, que o ideal é que os locais escolhidos, possuam atributos físicos e humanos para tal, ou seja, pode-se aproveitar, por exemplo, fundos de vales, para esta atividade, outra escolha seria, que se distanciasse de sítios urbanos, ou em áreas que não possuam cursos d'água próximos, bem como durante licenciamentos de novos loteamentos, exigir a coleta seletiva, como forma de mitigar os impactos.

\begin{tabular}{|c|c|}
\hline $\begin{array}{c}\text { POPULAÇAO } \\
\text { (mil hab) }\end{array}$ & $\begin{array}{c}\text { PRODUÇAO DE LIXO } \\
\text { (kg/hab.dia) }\end{array}$ \\
\hline Até 100 & 0,4 \\
\hline 100 a 200 & 0,5 \\
\hline 200 a 500 & 0,6 \\
\hline Maior que 500 & 0,7 \\
\hline
\end{tabular}

Tabela 3.4-1: Um dos dados constantes em relatório sobre resíduos sólidos: valores de coeficiente per capita de produção de resíduos sólidos domiciliares, em função da população urbana. Fonte: CETESB, 2.007.

$\mathrm{Na}$ prática, esses dados oficiais são sempre sub-dimensionados e a produção de resíduos nos municípios, com regra geral, é maior do que esta média sistematizada pela CETESB, contudo, trata-se de uma fonte oficial de dados, que não deve ser negligenciada e sim complementada por informações obtidas em pesquisas de campo e análise bibliográfica.

\subsection{Climatológico}

O estudo das condições climáticas é uma importante ferramenta de subsídio à análise para os órgãos ambientais licenciadores, uma vez que as características do clima influenciam diretamente à paisagem existente, assim como a paisagem existente pode influenciar no microclima de um local.

A caracterização do clima e condições meteorológicas da área potencialmente atingida pelo empreendimento pode incluir:

- perfil do vento, temperatura e umidade do ar (...);

- componentes do balanço hídrico do solo;

- nebulosidade (...), precipitação (...), delimitação do período seco e chuvoso (...) (Rodrigues, 2002, p. 83, 84) 
O relatório climatológico, como tema de análise "busca esclarecer a influência desse elemento na vida, na saúde, na distribuição e nas atividades humanas da área planejada." (Santos, 2004, p. 75)

As atividades humanas tais como a urbanização, industrialização, desmatamento, agropecuária, a construção de represas, podem influenciar nos aspectos climáticos de uma região, acabando muitas vezes, por constituir um clima particular de uma dada porção do território, denominado, assim, de "microclima".

A climatologia geográfica preocupa-se, fundamentalmente, com seu papel na elaboração das paisagens e do mosaico espacial, no qual é, também, muito relevante o papel da história, da cultura e do modelo econômico. Concentra suas atenções na superfície do planeta, onde se dá a conexão dos processos atmosféricos, geomorfológicos, hidrológicos e biológicos e onde o homem, vivendo em sociedade, produz e organiza o espaço, isto é, constrói seu ecúmeno. (...) Não é difícil entender essa estreita associação, uma vez que, na análise da paisagem, o clima é o agente exógeno de maior interferência. (Conti, 2001, 92)

Neste estudo busca-se fornecer subsídios ao órgão ambiental, no sentido da compreensão do clima na localidade em que se insere o empreendimento a ser licenciado.

Este subsídio pode levar o órgão ambiental a exigir medidas de caráter preventivo, quando, por exemplo, irá ocorrer uma grande supressão de vegetação, a qual pode ocasionar em uma exposição do solo, às vezes susceptível a erosão; ou quando se pretende impermeabilizar grandes áreas, outrora ocupadas por campos antrópicos ou maciços florestais, acarretando em pequenas ilhas de calor, fazendo com que se deixem áreas, igualmente permeáveis ou novos plantios para mitigar este impacto; ou ainda cuidados ao se empreender novas instalações em áreas com grandes índices pluviométricos, tal qual em certas porções do litoral norte paulista; aumento da vulnerabilidade à enchentes, pelas impermeabilizações executadas; entre outros.

Assim, o estudo que aborda os aspectos climáticos do local de implantação do empreendimento, determina o impacto causado por esta modificação e igualmente propõe medidas de mitigação como forma de minimizar o referido impacto e viabilizar o empreendimento de forma equilibrada. 
- As disciplinas do curso de Geografia, que preparam o profissional para este relatório são, sobretudo, aquelas do eixo climatológico, como a Climatologia I e II, e Estágio Supervisionado em Climatologia, disciplina optativa, que alguns alunos decidem cursar. As disciplinas como Cartografia temática e Ambiental, também contribuem para a elaboração dos mapas, que podem vir a ser inseridas sobre esta temática (em alguns casos). São importantes também, as disciplinas de Sensoriamento Remoto, Aerofotogeografia e Cartografia Ambiental, todas que de certa forma auxiliam na interpretação das fotografias aéreas e das imagens de satélite, que permitem identificar áreas naturais e áreas antrópicas, de onde se pode pensar em fazer medições de temperatura, umidade do ar, como comparação de um cenário futuro em área que possa vir a ser modificada.

Outras disciplinas subsidiam indiretamente, os geógrafos na elaboração deste relatório, como por exemplo, Biogeografia, Hidrografia, Geomorfologia, Pedologia, todas que tem no clima um fator delineador de sua gênese e transformação, subsidiando assim a compreensão da área de estudo e de sua área de influência, possibilitando, numa análise mais ampla, entender como se dão processos erosivos, ou enchentes, por exemplo.

As disciplinas de Geografia Urbana, Econômica e das Indústrias, também podem contribuir nos estudos climatológicos, pois dependendo da localização do empreendimento, sabe-se que o clima poderá ser influenciado, ora pela urbanização local e regional, ora pela quantidade de indústrias poluidoras ou não, daquele sítio, que dependendo do adensamento construtivo, pode haver um microclima relacionado ao nível de insolação e sombras, por exemplo.

- Os artigos da Lei $n^{\circ} 6.664$, a qual disciplina a profissão de geógrafo, que amparam legalmente a elaboração deste relatório são, sobretudo, estes listados na seqüência:

f) na caracterização ecológica e etológica da paisagem geográfica e problemas conexos;

j) no estudo e planejamento das bases físicas e geoeconômicas dos núcleos urbanos e rurais;

I) no aproveitamento, desenvolvimento e preservação dos recursos naturais;

- Os conceitos e as habilidades técnicas que se relacionam com as disciplinas de apoio acima mencionadas são, sobretudo, os ligados à Geomorfologia, como 
delimitante das caracterizações climáticas, com fatores como altitude e proximidade do mar, por exemplo; da Biogeografia, com a delimitação de áreas naturais e sua ligação com a evapotranspiração das árvores, por exemplo; e evidentemente a climatologia, com a compreensão dos climas particulares e zonais, a partir de critérios geomorfológicos, biogeográficos, regionais e antrópicos.

O Gráfico a seguir, apresenta a precipitação média no período climatológico 1961 / 1990. As normais climatológicas se constituem em parâmetros com credibilidade científica, uma vez, que são tomados num período de 30 anos, assim, desprezando, variações normais de curto prazo.

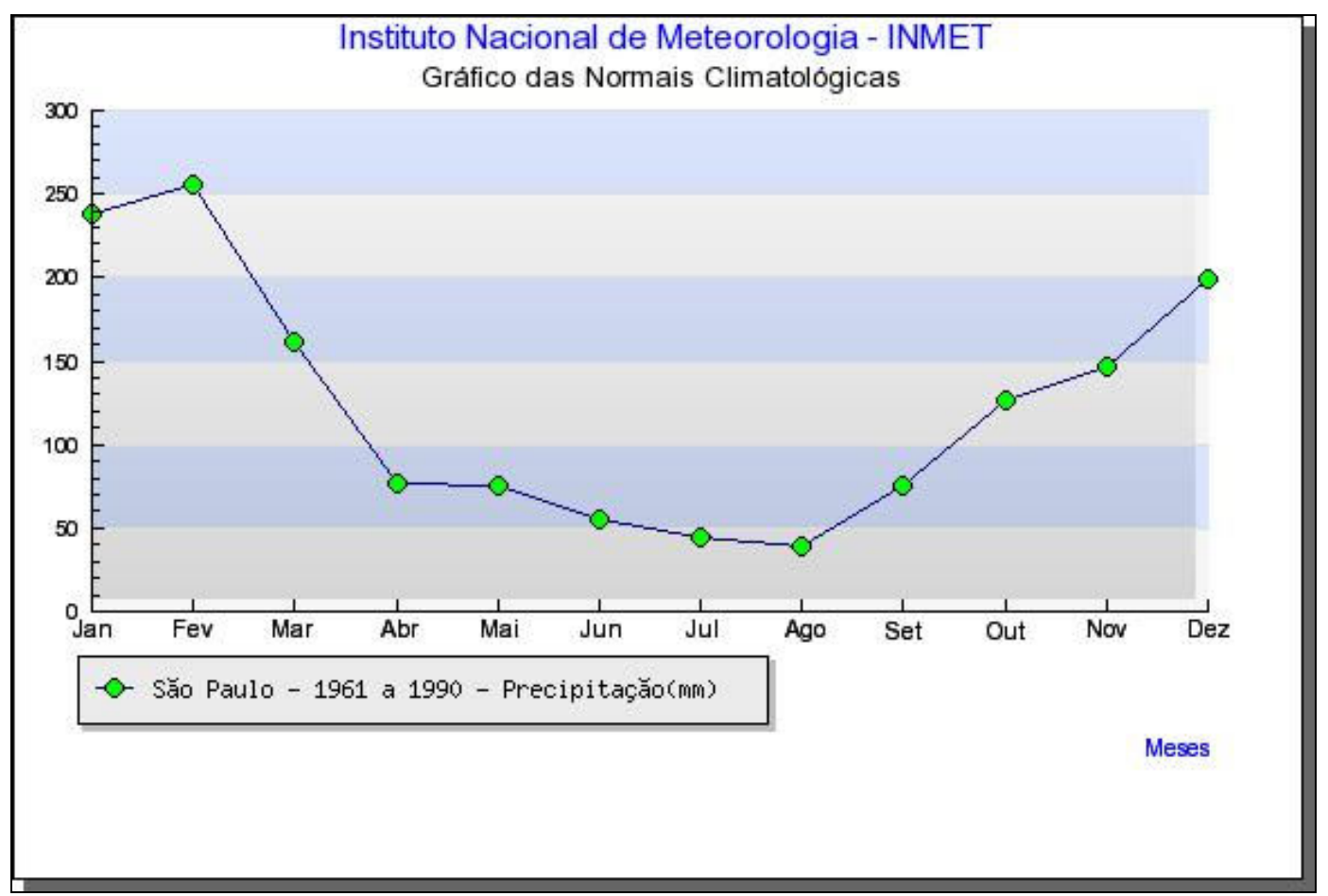

Figura 3.5-1: Precipitação Média no Município de São Paulo, período de "Normais Climatológicas" 1961 a 1990. Fonte: INMET, 2007.

Um dos parâmetros exigidos pelos órgãos ambientais para a compreensão da área objeto de licenciamento. Os dados podem ser de fontes oficiais ou obtidos em trabalho de campo, dependendo do tipo de trabalho e área em que se localiza.

\subsection{Qualidade do Ar}


Aqui cabe uma consideração inicial, empreendimentos que deverão causar impacto substancial na qualidade do ar local e regional (de acordo com critérios adotados, para cada empreendimento) devem ser precedidos de estudos de dispersão atmosférica, estes, elaborados por profissionais com capacitação técnica e legal para fazê-lo, tais como físicos ou engenheiros químicos, embora muitas vezes, sejam utilizados softwares para projeções de impactos e que poderiam ser usados, até por outros profissionais, mas de qualquer forma, os geógrafos não tem elaborado estes estudos, mas somente estudos de qualidade do ar, menos densos, para empreendimentos, com impactos reduzidos neste aspecto ambiental.

O estudo de qualidade do ar consiste em demonstrar os índices oficiais obtidos, provenientes "de estações de amostragem existentes" para a localidade que receberá o novo empreendimento e "a compilação de dados climatológicos provenientes de estações meteorológicas", simulando ainda o impacto que esse pode acarretar ao lugar em questão. "Para certos tipos de empreendimentos também se faz a coleta de dados primários, com a instalação de amostradores ${ }^{6}$." (Sánchez, 2008, p. 238)

A mensuração da qualidade do ar de um lugar ou de uma região é obtida pela quantificação das substâncias poluentes existentes na atmosfera, que são comparadas com os padrões de concentrações estabelecidos pela legislação ambiental.

A movimentação vertical da atmosfera está relacionada com a circulação atmosférica regional, cujos principais agentes são as massas de ar, as quais criam condições para que as parcelas de ar subam ou desçam, através dos movimentos convectivos ascendentes ou descendentes, em função das características de temperaturas e pressão predominantes, num dado momento, propiciando atmosferas com variado grau de estabilidade.

As situações em que esse movimento vertical se configure de forma a permitir a subida do ar quente, contribuindo para a formação de nuvens e por consequência na

\footnotetext{
${ }^{6} \mathrm{O}$ equipamento mais usado é o amostrador de grandes volumes ( $\left.\mathrm{Hi}-\mathrm{Vol}\right)$, este, já tivemos a oportunidade de vê-lo sendo operado, em áreas de mineração, por profissionais de nível médio, portanto, não exigindo grandes habilidades técnicas, mas sim um treinamento específico para o uso.
} 
precipitação pluvial, criam-se cenários favoráveis à melhoria da qualidade do ar, ou seja, a chuva agindo com um importante depurador da atmosfera, principalmente em relação às partículas em suspensão.

Cabe ressaltar que, mesmo com emissões de poluentes atmosféricos constantes ao longo do ano, a qualidade do ar pode mudar em função das condições meteorológicas que determinam uma maior ou menor diluição dos poluentes, a precipitação é um bom exemplo a ser destacado.

- As disciplinas do curso de Geografia, que preparam o profissional para este relatório são, como mencionado, no relatório anterior, Climatologia I e II, Geografia urbana, das Indústrias, Geografia Agrária e Geomorfologia, pois em todas há elementos que perpassam pela questão da poluição atmosférica, seja pelo sítio urbano e sua enorme concentração de veículos automotores, seja pela concentração de indústrias, que em diferentes níveis, causam alguma poluição atmosférica, bem como as áreas rurais, que, também, contribuem para a poluição do ar, seja por exemplo, pela queima da palha da cana, ou pelo próprio desmatamento para criação de novas áreas, para usos agropecuários, residenciais, comerciais ou industriais.

- Os artigos da Lei $n^{\circ} 6.664$, a qual disciplina a profissão de geógrafo, que amparam legalmente a elaboração deste relatório são, sobretudo, estes listados na seqüência:

f) na caracterização ecológica e etológica da paisagem geográfica e problemas conexos;

j) no estudo e planejamento das bases físicas e geoeconômicas dos núcleos urbanos e rurais;

I) no aproveitamento, desenvolvimento e preservação dos recursos naturais;

m) no levantamento e mapeamento destinados à solução dos problemas regionais;

- Os conceitos e as habilidades técnicas que se relacionam com as disciplinas de apoio acima mencionadas são, sobretudo, os relacionados à climatologia e geomorfologia, pois a qualidade do ar de um determinado lugar pode vir a degradar a de outra localidade, e os aspectos que ancoram este fato, são, sem dúvida, a dispersão atmosférica (por ventos e massas de ar) e a geomorfologia (barreiras 
geográficas podem concentrar os poluentes em determinados lugares, bacias ou fundos de vales, por exemplo).

A apreensão do espaço e da própria região em que se encontrará o empreendimento a ser licenciado possibilitará, com o auxilio de fotos e imagens de satélite, diagnosticar para onde irão se dispersar os poluentes gerados pelo novo empreendimento, quando estes existirem, evidentemente.

Assim, o geógrafo, com sua formação crítica poderá avaliar, quais os reais impactos adicionados pelo empreendimento, no aspecto da qualidade do ar e atentar para a mitigação em relação às populações afetadas nesta região de estudo.

Um exemplo de parâmetro abordado nos estudos de qualidade do ar se refere ao monóxido de carbono (CO), como exemplo, na figura abaixo, pode-se verificar as máximas de concentração médias de 8 horas de $C O$, para as estações na Região Metropolitana de São Paulo (RMSP) e algumas cidades do interior. Na RMSP, foram registradas ultrapassagens do padrão (9ppm) nas estações São Caetano do Sul e Taboão da Serra. 


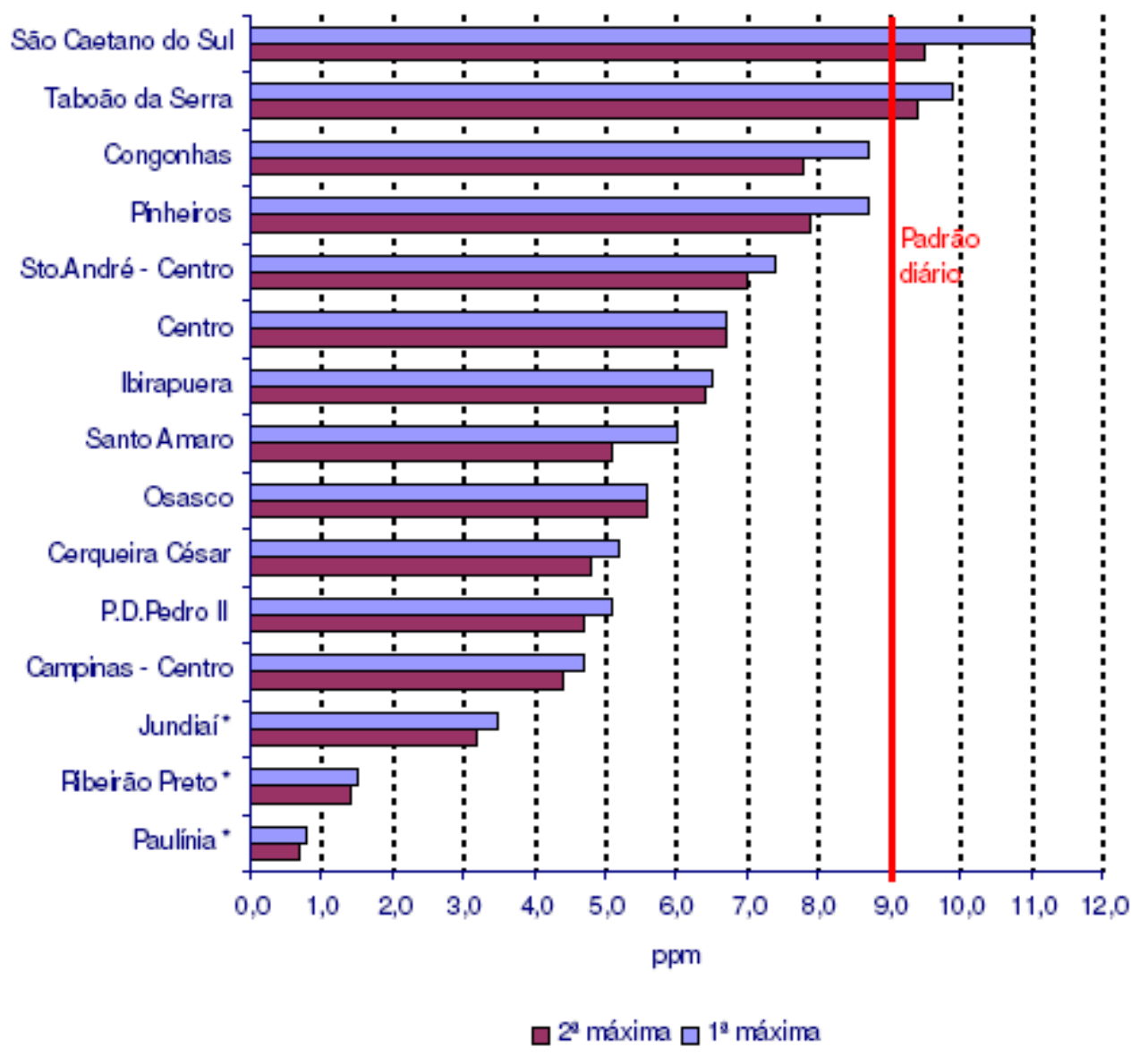

* Não atendeu ao critério de representatividade.

Figura 3.6-1: CO - Máximas (8 horas) - RMSP e Interior - 2006. Fonte: CETESB, 2006.

Há muita informação e dados disponibilizados pela CETESB, em relação à qualidade do ar no Estado de São Paulo, que contribuem para a realização de estudos dotados de informações oficiais, importantes para o embasamento dos mesmos.

\subsection{Geomorfológico}

Este relatório consiste no estudo prévio das classes de declividade existentes no terreno a ser estudado, bem como no mapeamento e confirmação em campo da topografia da área, suas declividades e seu enquadramento na lei, inclusive como áreas de preservação permanente, informações estas para a área diretamente afetada. 
Já no aspecto do enquadramento do empreendimento na região de estudo, região aqui entendida pelos seus atributos geomorfológicos, a caracterização pode conter:

- compartimentação topográfica geral das áreas de estudo (planalto, depressão, planície); (...)

- tipo de forma de relevo dominante (cristas, colinas, planície fluvial, etc);

- presença eventual de grandes massas de relevo ou pontos muito elevados nas imediações (cristas, serras, picos, morros isolados, etc);

- posição da área em relação aos principais acidentes de relevo (topo, encosta, sopé, etc);

- classificação das formas de relevo quanto à sua origem (formas cársticas, formas fluviais, formas de aplainamento, formas litorâneas, etc);

- características dinâmicas do relevo (presença ou propensão à erosão acelerada e assoreamento, áreas sujeitas a inundações, áreas sujeitas à erosão eólica, etc). (Rodrigues, 2002, p. 85)

O diagnóstico geomorfológico da área de estudo:

Permite deduzir a tipologia e intensidade dos processos erosivos e deposicionais, a distribuição, textura e composição dos solos, bem como a capacidade potencial de uso. Associados a outros elementos do meio, os dados de geomorfologia podem auxiliar na interpretação de fenômenos como inundações e variações climáticas locais. (Santos, 2004, p. 78)

É também neste relatório que se podem verificar informações sobre "os fenômenos hidrológicos, declividade, velocidade de drenagem" (Santos, 2004, p. 78), as quais vão permitir uma melhor ocupação do terreno e muitas vezes menores custos de implantação e menor modificação do ambiente.

O estudo geomorfológico da área de influência indiretamente afetada pelo novo empreendimento destaca a região a ser estudada sob o enfoque de um atributo físico, que pode ser uma planície, um relevo montanhoso e que irá influenciar no tipo de ocupação que queira se dar, a partir da nova implantação pleiteada.

Pode se afirmar que:

A "geomorfologia promove, por meio de estudos da dinâmica do relevo, a compreensão do funcionamento da paisagem ao incorporar os outros componentes da natureza, estabelecendo relações entre relevo e solos, relevo e clima, relevo e hidrografia, cobertura vegetal e substrato geológico." (Venturi, 2008, p. 84)

- As disciplinas do curso de Geografia, que preparam o profissional para este relatório são, sobretudo, a Geomorfologia I e II, e a optativa, Estágio Supervisionado 
em Geomorfologia, as quais preparam o geógrafo para a compreensão dos aspectos relacionados a este tema.

Disciplinas como a Cartografia Temática, Sensoriamento Remoto, Aerofotogeografia e Cartografia Ambiental, Hidrografia e Pedologia, também contribuem para que o geógrafo produza relatórios geomorfológicos embasados, não se limitando apenas a um aspecto, mas sim no entendimento da realidade posta, como um todo integrado, uma paisagem a ser analisada, ou até mesmo uma região, dependendo do enfoque a ser dado.

Assim, disciplinas mais teóricas, como Teoria Geográfica da Paisagem e Teoria da Região, podem contribuir na elaboração de um relatório geomorfológico existente dentro dos EIAs.

Até mesmo, disciplinas, consideradas da Geografia humana, participam indiretamente deste relatório, aguçando a percepção da escolha dos lugares de relevo mais suave, e em localidades mais valorizadas para os mais bem dotados financeiramente, em detrimento de áreas insalubres, íngremes, impróprias aos menos abastados.

Há também aquelas disciplinas, que favorecem o aprendizado de ferramentas ligadas à informática: Microinformática Instrumental em Geografia, Introdução aos Sistemas de Informações Geográficas e que contribuem para a melhor elaboração do(s) mapa(s) e na identificação de áreas mais apropriadas a introdução do novo empreendimento.

- Os artigos da Lei $n^{\circ}$ 6.664, que disciplina a profissão de geógrafo e amparam legalmente a elaboração deste relatório são, sobretudo, estes listados na sequência:

a) na delimitação e caracterização de regiões, sub-regiões geográficas naturais e zonas geoeconômicas, para fins de planejamento e organização físico-espacial;

b) no equacionamento e solução, em escala nacional, regional ou local, de problemas atinentes aos recursos naturais do País;

c) na interpretação das condições hidrológicas das bacias fluviais;

d) no zoneamento geo-humano, com vistas aos planejamentos geral e regional;

f) na caracterização ecológica e etológica da paisagem geográfica e problemas conexos;

g) na política de povoamento, migração interna, imigração e colonização de regiões novas ou de revalorização de regiões de velho povoamento; 
h) no estudo físico-cultural dos setores geoeconômicos destinados ao planejamento da produção;

j) no estudo e planejamento das bases físicas e geoeconômicas dos núcleos urbanos e rurais;

I) no aproveitamento, desenvolvimento e preservação dos recursos naturais;

$\mathrm{m})$ no levantamento e mapeamento destinados à solução dos problemas regionais;

- Os conceitos e as habilidades técnicas que se relacionam com as disciplinas de apoio acima mencionadas são, sobretudo, os de região e paisagem, na delimitação das áreas de influência do empreendimento, bem como as unidades geomorfológicas do estado de São Paulo, ou do país, planaltos, depressões e planícies. Nos aspectos técnicos, as ferramentas de microinformática, sensoriamento remoto e cartografia, com o aprendizado de programas específicos, como o Spring e o llwis, atualmente utilizados em algumas disciplinas. Para o reconhecimento de campo, as ferramentas da disciplina Técnicas de Campo e Laboratório também contribuem para a realização deste relatório, assim como o aprendizado nos trabalhos de campo do curso como um todo, cada disciplina cooperando de forma direta e indireta para a apreensão da área de estudo.

Cabe mencionar, que o relatório geomorfológico é um dos constantes nos EIAs, que tem o poder de delimitar porções do terreno, alvo de licenciamento, de serem ou não ocupadas, uma vez que existem Áreas de Preservação Permanente (APPs) relacionadas a altitudes e declividades, contempladas no Código Florestal 4.771/65, tais como:

d) no topo de morros, montes, montanhas e serras;

e) nas encostas ou partes destas, com declividade superior a $45^{\circ}$, equivalente a $100 \%$ na linha de maior declive;

f) nas restingas, como fixadoras de dunas ou estabilizadoras de mangues;

g) nas bordas dos tabuleiros ou chapadas, a partir da linha de ruptura do relevo, em faixa nunca inferior a 100 (cem) metros em projeções horizontais; (Redação dada pela Lei $n^{\circ} 7.803$ de 18.7.1989)

h) em altitude superior a 1.800 (mil e oitocentos) metros, qualquer que seja a vegetação.

Bem como, muitas vezes, antes mesmo da elaboração do EIA, há contratos de prestação de serviços para se analisar a geomorfologia do local a ser licenciado, de modo a verificar sua viabilidade ambiental e financeira, uma vez que impedimentos 
legais podem fazer com que empreendedores desistam de comprar determinadas áreas, ao saberem do uso restrito devido aos aspectos de geomorfologia.

Portanto, o estudo geomorfológico é muita importante dentro dos EIAs e sua elaboração exige uma dose grande de responsabilidade, podendo favorecer ou inviabilizar um área.

\subsection{Caracterização Pedológica}

Este capítulo, nos estudos de impacto ambiental, só pode ser assinado pelos engenheiros agrônomos, mas poderia sê-lo também por geógrafos e geólogos, os quais também possuem capacidade técnica para caracterizar o tipo de solo para os estudos citados, sem prejuízos para a qualidade do mesmo, para que isso seja feito usa-se o subterfúgio de nomeação do relatório como "esboço pedológico".

No esboço pedológico expõem-se as potencialidades e fragilidades do solo em que se vai empreender uma nova implantação, de forma descritiva e também por meio do mapeamento do local e de suas áreas de influência, seja sob o enfoque regional, seja sob o enfoque da paisagem dotada de um determinado tipo de ocupação da superfície, ou através de dados secundários (mapas temáticos produzidos por órgãos oficiais e disponibilizados).

O clima, a topografia, os materiais de origem, a biota e o tempo são os fatores que determinam as características dos solos e das quais depende o seu equilíbrio dinâmico. Qualquer mudança em uma dessas variáveis certamente irá afetar o solo. As reações a uma determinada mudança ambiental irão variar de solo para solo, em função da sua sensibilidade a cada tipo de tensão.

Aos fatores que determinam as características do solo deve-se acrescentar a ação antrópica, uma vez que ela, mesmo que a nível local, assume maior poder de interferência que o conjunto dos fatores naturais. (Bastos; Freitas, 2002, p. 31)

- As disciplinas do curso de Geografia, que preparam o profissional para este relatório são, sobretudo, a Geologia, Pedologia e Solos Tropicais, esta última optativa; indiretamente, disciplinas como Hidrografia, Biogeografia e Geomorfologia, também subsidiam a compreensão dos solos de maneira integradora, como é o curso de Geografia. 
Cartografia Temática, Sensoriamento Remoto, Aerofotogeografia e Cartografia Ambiental, todas que de certa forma auxiliam na interpretação das fotografias aéreas e das imagens de satélite e que posteriormente permitem a elaboração do mapeamento e descrição deste relatório, também tem importância para a pedologia.

- Os artigos da Lei $n^{\circ} 6.664$, a qual disciplina a profissão de geógrafo, que poderiam amparar legalmente a elaboração deste relatório são, sobretudo, estes listados na seqüência:

a) na delimitação e caracterização de regiões, sub-regiões geográficas naturais e zonas geoeconômicas, para fins de planejamento e organização físico-espacial;

b) no equacionamento e solução, em escala nacional, regional ou local, de problemas atinentes aos recursos naturais do País;

f) na caracterização ecológica e etológica da paisagem geográfica e problemas conexos;

g) na política de povoamento, migração interna, imigração e colonização de regiões novas ou de revalorização de regiões de velho povoamento;

h) no estudo físico-cultural dos setores geoeconômicos destinados ao planejamento da produção;

j) no estudo e planejamento das bases físicas e geoeconômicas dos núcleos urbanos e rurais;

I) no aproveitamento, desenvolvimento e preservação dos recursos naturais;

m) no levantamento e mapeamento destinados à solução dos problemas regionais;

- Os conceitos e as habilidades técnicas que se relacionam com as disciplinas de apoio acima mencionadas são, sobretudo, os de compartimentação geomorfológica, região e paisagem; a caracterização pedológica, com vistas a possibilitar a ocupação da melhor forma possível, delimitando porções em que o solo seja adequado para determinados fins, ou que não o seja.

Nos aspectos técnicos, as ferramentas de microinformática, sensoriamento remoto e cartografia, com o aprendizado de programas específicos facilitam a elaboração dos mapas pedológicos, na escala local; uma vez que em escala regional, muitas vezes, se usam mapas oficiais já disponíveis.

\subsection{Hidrologia}

Muitos aspectos dos meios físico e biótico, constantes nos estudos de impacto ambiental, consideram a bacia hidrográfica como instrumento de análise e de 
mensuração de modificação da paisagem, seja por definição da equipe envolvida na elaboração dos relatórios, seja por exigências legais, as quais, por vezes, determinam que seja a própria bacia hidrográfica adotada para previsão dos impactos.

A análise de bacias hidrográficas começou a apresentar caráter mais objetivo a partir de 1945, com a publicação do notável trabalho do engenheiro hidráulico Robert E. Horton, que procurou estabelecer as leis do desenvolvimento dos rios e de suas bacias. A Horton cabe a primazia de efetuar a abordagem quantificativa das bacias de drenagem, e o seu estudo serviu de base para nova concepção metodológica e originou inúmeras pesquisas por parte de vários seguidores. Não é justo que se esqueça, na utilização e expansão dessa nova perspectiva, da influência exercida por Arthur N. Strahler e dos seus colaboradores da Universidade de Colúmbia. (Christofoletti, 1976, p. 85)

Por se constituir em uma delimitação física rígida, a bacia hidrográfica é comumente tratada nos estudos de impacto ambiental como área de influência indireta, dependendo de sua dimensão em área de influência direta, dependendo do tipo de empreendimento e dos impactos trazidos por ele.

As bacias de drenagem funcionam cada uma com sua própria série de depósitos e de transferências das águas que entram. Os escoamentos, em muitos casos, podem reunir-se antes de alcançar o mar. O homem, com suas interferências, pode alterar a eficiência e a capacidade de muitas das armazenagens e transferências. (Bastos; Freitas, 2002, p. 24)

Assim, preliminarmente deduz-se que "toda ocorrência de eventos em uma bacia hidrográfica, de origem antrópica ou natural, interfere na dinâmica desse sistema, na quantidade de cursos de água e sua qualidade." Pois, "uma bacia hidrográfica circunscreve um território drenado por um rio principal, seus afluentes e subafluentes permanentes ou intermitentes." (Santos, 2004, p. 85)

Para empreendimentos que possam afetar a quantidade de água disponível, são necessários estudos hidrológicos, os quais geralmente se baseiam em redes de estações pluviométricas e fluviométricas existentes e operadas por órgãos governamentais. Séries históricas de dados de chuva e vazão são trabalhados estatisticamente para fornecer informação sobre vazões máxima, média e mínima e altura de rios, e sobre intensidade pluviométrica (...) para diferentes períodos de retorno. (Sánchez, 2008, p. 237)

- As disciplinas do curso de Geografia, que preparam o profissional para este relatório são, sobretudo, Hidrografia e Geomorfologia, além de todas do eixo 
cartográfico, como a Cartografia Sistemática, Temática, Sensoriamento Remoto, Aerofotogeografia e Cartografia Ambiental, que de certa forma auxiliam na interpretação das fotografias aéreas e das imagens de satélite, permitindo o entendimento e a delimitação da bacia hidrográfica envolvida na análise do empreendimento ora em licenciamento.

- Os artigos da Lei $n^{0}$ 6.664, a qual disciplina a profissão de geógrafo, que amparam legalmente a elaboração deste relatório são, sobretudo, estes listados a seguir:

a) na delimitação e caracterização de regiões, sub-regiões geográficas naturais e zonas geoeconômicas, para fins de planejamento e organização físico-espacial;

b) no equacionamento e solução, em escala nacional, regional ou local, de problemas atinentes aos recursos naturais do País;

c) na interpretação das condições hidrológicas das bacias fluviais;

f) na caracterização ecológica e etológica da paisagem geográfica e problemas conexos;

h) no estudo físico-cultural dos setores geoeconômicos destinados ao planejamento da produção;

j) no estudo e planejamento das bases físicas e geoeconômicas dos núcleos urbanos e rurais;

I) no aproveitamento, desenvolvimento e preservação dos recursos naturais;

$\mathrm{m})$ no levantamento e mapeamento destinados à solução dos problemas regionais;

Nos aspectos técnicos, as ferramentas de microinformática, sensoriamento remoto e cartografia, por meio do aprendizado de programas facilitam a delimitação e compreensão da bacia hidrográfica envolvida na análise.

Para o reconhecimento de campo, as ferramentas da disciplina Técnicas de Campo e Laboratório também contribuem para a realização deste relatório, assim como o aprendizado nos trabalhos de campo do curso de Hidrografia, com o aprendizado de estudos de vazão, delimitação de ordens dos rios, apreensão dos impactos causados por grandes áreas impermeabilizadas e o próprio entendimento de bacia hidrográfica, enquanto elemento físico de importância nos EIAs.

A ocupação das margens dos cursos d'água se reveste, num fator impeditivo, para o licenciamento de determinados empreendimentos, por se constituírem em áreas de Preservação Permanente (APP), tal qual mencionado no Código Florestal, 4.771/65:

a) ao longo dos rios ou de qualquer curso d'água desde o seu nível mais alto em faixa marginal cuja largura mínima será: (Redação dada pela Lei $n^{\circ} 7.803$ de 18.7.1989) 
1 - de 30 (trinta) metros para os cursos d'água de menos de 10 (dez) metros de largura; (Redação dada pela Lei $n^{\circ} 7.803$ de 18.7.1989);

2 - de 50 (cinquenta) metros para os cursos d'água que tenham de 10 (dez) a 50 (cinquenta) metros de largura; (Redação dada pela Lei $n^{\circ} 7.803$ de 18.7.1989);

3 - de 100 (cem) metros para os cursos d'água que tenham de 50 (cinquenta) a 200 (duzentos) metros de largura; (Redação dada pela Lei $\mathrm{n}^{\circ} 7.803$ de 18.7.1989);

4 - de 200 (duzentos) metros para os cursos d'água que tenham de 200 (duzentos) a 600 (seiscentos) metros de largura; (Redação dada pela Lei $n^{\circ}$ 7.803 de 18.7.1989);

5 - de 500 (quinhentos) metros para os cursos d'água que tenham largura superior a 600 (seiscentos) metros; (Incluído pela Lei $n^{\circ} 7.803$ de 18.7.1989);

b) ao redor das lagoas, lagos ou reservatórios d'água naturais ou artificiais;

c) nas nascentes, ainda que intermitentes e nos chamados "olhos d'água", qualquer que seja a sua situação topográfica, num raio mínimo de 50 (cinquenta) metros de largura; (Redação dada pela Lei $n^{0} 7.803$ de 18.7.1989).
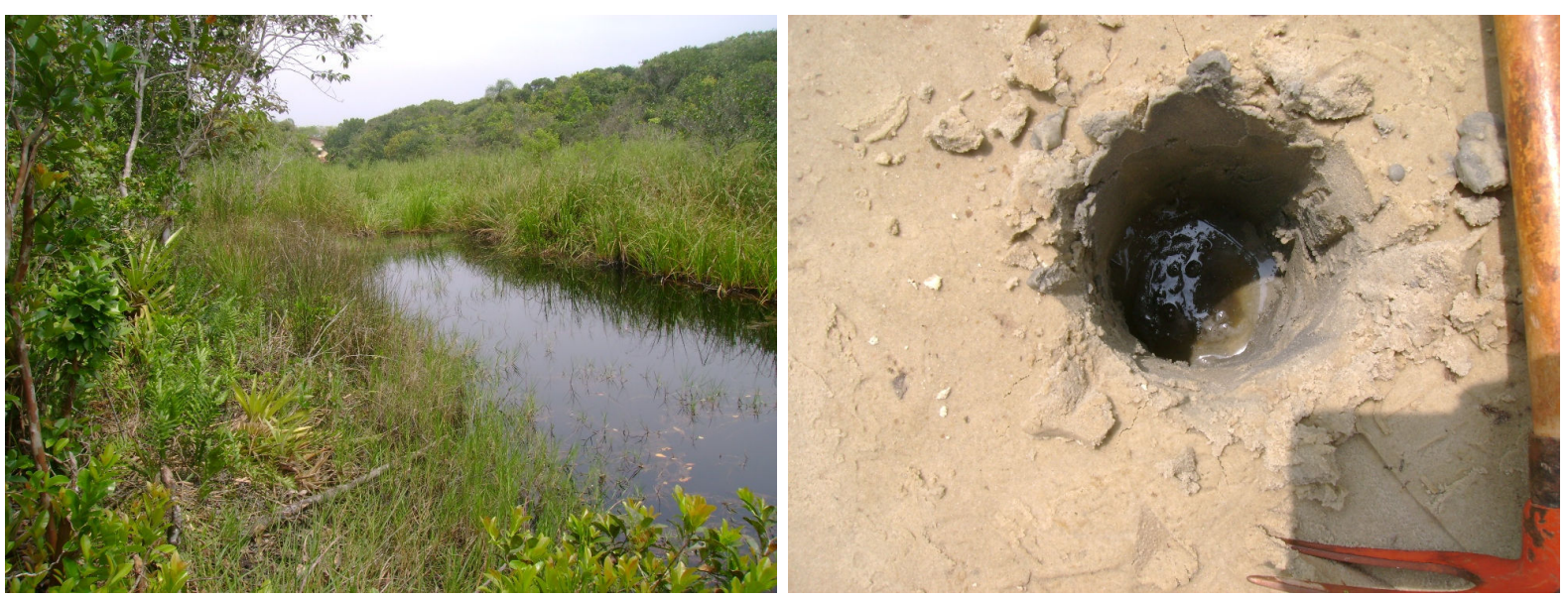

Figuras 3.9-1 e 2: A esquerda, vista parcial da Lamina d'água ocorrente na propriedade e a direita, vista de um furo de sondagem a trado manual executado na área, evidenciando o fluxo de água no interior do banco de areia existente.

É comum, que a menção às APPs conste no relatório de Vegetação, mas ocorre, em alguns casos, de sua abordagem, também no relatório hidrográfico.

\subsection{Caracterização da Vegetação}

Os relatórios de vegetação, constantes nos EIAs são indicadores de qualidade ambiental, muito estimados na análise dos órgãos licenciadores, por vários motivos, pelo aspecto de valorização da paisagem local, pelo abrigo de fauna, pela proteção dos solos, pela capacidade de fixação de carbono, entre tantos outros. 
Removendo a cobertura florestal de uma determinada área, reduz-se instantaneamente a transferência de nutrientes minerais do solo para a biomassa, tal como o volume acumulado de biomassa. A água passa a remover nutrientes do solo por lixiviação e escoamento, enquanto o aporte de águas pluviais sofre um aumento devido à falta de obstáculo que as copas das árvores proporcionavam, suavizando seu impacto com o solo. (Bastos; Freitas, 2002, p. 30)

Trata-se da caracterização dos estágios sucessionais de vegetação existente no local, que receberá o novo empreendimento, a citação de alguns exemplares arbóreos ali existentes, e por vezes, o próprio cadastramento arbóreo (este, não passível de execução pelo geógrafo), a quantificação (em $\left.\mathrm{m}^{2}\right)$, e o mapeamento dos fragmentos.

Neste relatório inserem-se também as áreas de preservação permanente - APPs, relacionadas aos cursos d'água e nascentes, as quais são dimensionadas a partir, por exemplo, do Código Florestal Brasileiro, cujos limites de uso estão condicionados com o respeito de faixas que devem ser preservadas, conforme mencionado acima no relatório hidrológico.

- As disciplinas do curso de Geografia, que preparam o profissional para este relatório são, sobretudo, Biogeografia, com o aporte teórico sobre vegetação e a constatação em trabalhos de campo; Sensoriamento Remoto, Cartografia Ambiental e Cartografia Temática, que auxiliam na interpretação das fotografias aéreas e das imagens de satélite e posteriormente permitem a elaboração do mapeamento e descrição dos dados sobre vegetação.

De grande relevância também é o uso dos domínios de natureza do Brasil (Ab'Saber, 2003), amparando a conceituação regional da vegetação estudada.

- Os artigos da Lei $n^{\circ}$ 6.664, a qual disciplina a profissão de geógrafo, que amparam legalmente a elaboração deste relatório são, sobretudo, estes listados na seqüência:

I - reconhecimentos, levantamentos, estudos e pesquisas de caráter físicogeográfico, biogeográfico, antropogeográfico e geoeconômico e as realizadas nos campos gerais e especiais da geografia, que se fizerem necessárias:

a) na delimitação e caracterização de regiões, sub-regiões geográficas naturais e zonas geoeconômicas, para fins de planejamento e organização físico-espacial;

f) na caracterização ecológica e etológica da paisagem geográfica e problemas conexos;

I) no aproveitamento, desenvolvimento e preservação dos recursos naturais; 
- Os conceitos e as habilidades técnicas que se relacionam com as disciplinas de apoio acima mencionadas são, sobretudo, os de região, paisagem e domínios, na delimitação das áreas de influência do empreendimento. Nos aspectos técnicos, as ferramentas de microinformática, sensoriamento remoto e cartografia são bastante úteis na elaboração do mapeamento da paisagem local e, por vezes, do domínio em que se encontra a área do empreendimento.

Para o reconhecimento de campo, as ferramentas e procedimentos adotados em Biogeografia, como o método de parcelas, o recolhimento de galhos e folhas para análise, quando não se consegue identificar em campo determinadas espécies, ou até mesmo elaborar desenhos em campo para posterior comparação com bibliografia especializada.

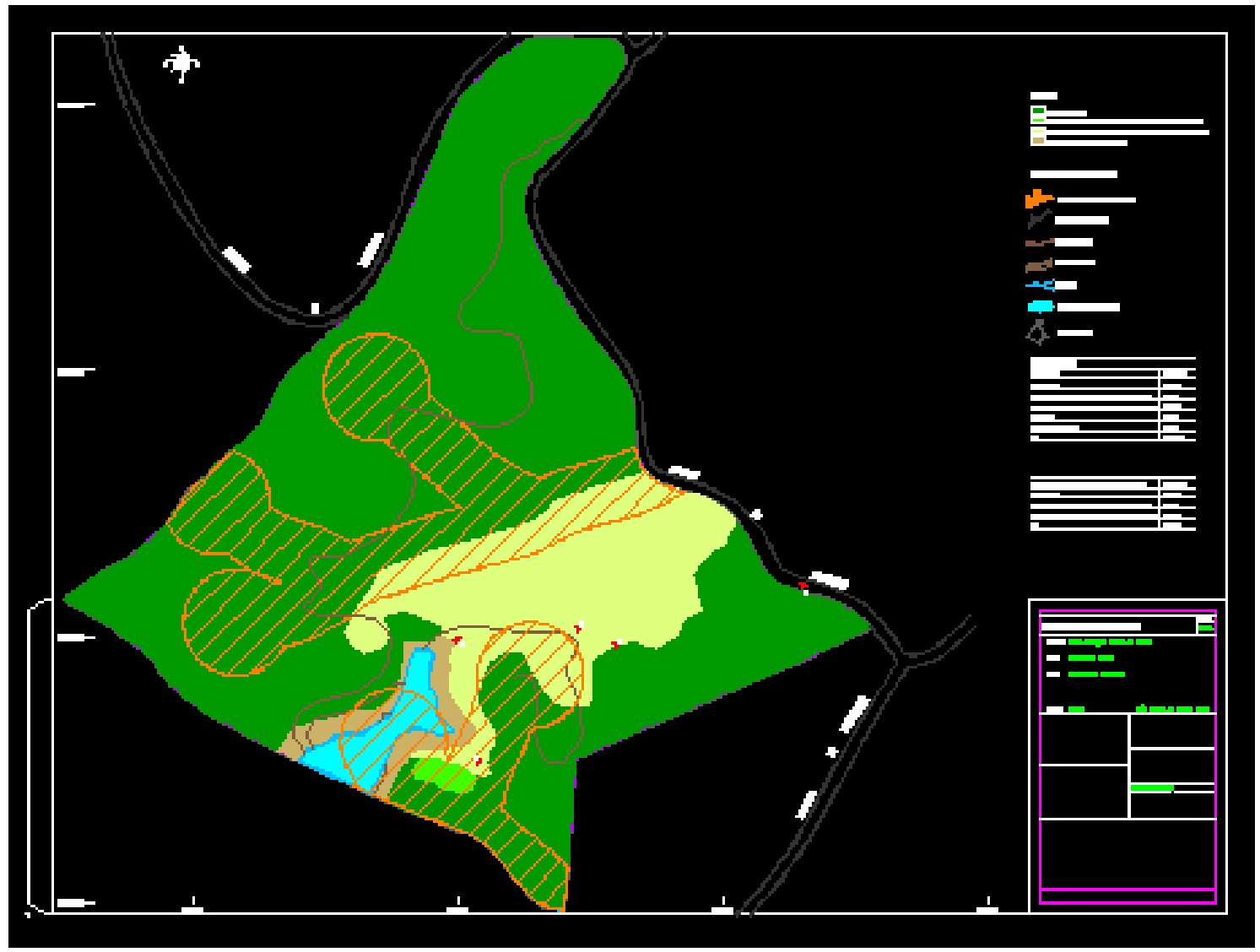

Mapa 3.10-1: Mapa de caracterização de vegetação elaborado para um trabalho realizado por este autor. 
Propositadamente, os dados encontram-se ilegíveis, por se tratar de área em licenciamento atualmente, portanto, confidencial. Em verde, reflorestamento de eucaliptos; em azul, hidrografia local; amarelo, campos antrópicos; em marrom, solo exposto e; tracejado laranja, áreas de preservação permanente de cursos d'água e nascentes.

\subsection{Cartografia / Geoprocessamento}

Embora não se trate de um relatório, mas sim parte integrante dos mesmos, é uma das áreas de atuação mais em evidência para os geógrafos que trabalham nos estudos de impacto ambiental. Trata-se de um setor para o qual, a busca de profissionais formados em Geografia ainda é grande, embora pessoas com outras formações também disputem este mercado, tal como desenhistas, projetistas, arquitetos, geólogos e técnicos ligados à informática em geral.

O método cartográfico (...) é de inestimável valor para os estudos geográficos. Tal como nas ciências geográficas, a cartografia observa as noções de espaço e de distribuição dos fatos e fenômenos, possibilitando, desta forma, estabelecer suas diferenciações e correlações. (Barbosa, 1968, p. 176)

A elaboração e apresentação de mapas são constantes em muitos dos relatórios presentes nos EIAs, às vezes como ilustração do texto descritivo e na maioria dos casos, como instrumento de análise, representados, por exemplo, por mapas geomorfológicos, de declividades, de vegetação, geológico, uso e ocupação do solo (terra), pedologia, climatologia etc.

Os "mapas são essenciais para a representação da maioria das informações produzidas ou compiladas pelos estudos de base." (Sánchez, 2008, p. 230) A espacialização de determinados atributos físicos, bióticos ou antrópicos são essências para a apreensão da gleba de estudo e de sua região de inserção, o geógrafo se constitui em um profissional habilitado para pensar essa espacialização, não só por estudar cartografia em sua grade curricular, mas por estudar uma cartografia que represente a espacialidade dos fenômenos e não como uma abstração a ser "desenhada". 
A utilização de fotografias aéreas, para pesquisas em Geografia iniciou-se na década de 1930, na Alemanha, com C. Troll; e a utilização de satélites, também para fins científicos, na década de 1970. Já,

"a partir do final da década de 1980 e, principalmente ao longo da década de 1990, inaugura-se uma nova fase no âmbito das tecnologias de informações. A informática, com o advento do tratamento de dados via computador, a produção de mapas digitais e o desenvolvimento de SIGs (Sistema de Informação Geográfica) e GPS (Global Position System), ampliou e dinamizou ainda mais a manipulação de dados, tanto no que se refere aos temas da sociedade como da natureza." (Ross, 2006, p. 200)

- As disciplinas do curso de Geografia, que preparam o profissional para este relatório são, sobretudo, aquelas do eixo cartográfico, como a Introdução a Cartografia, Cartografia Sistemática, Cartografia Temática, Sensoriamento Remoto, Aerofotogeografia e Cartografia Ambiental, todas que de certa forma auxiliam na interpretação das fotografias aéreas e das imagens de satélite, que posteriormente permitem a elaboração dos mapas a serem inseridos no EIA.

Muitos estudantes de Geografia, por conta própria, também buscam aperfeiçoamento nesta área, realizando cursos extracurriculares em programas mais avançados de Geoprocessamento e Sistemas de Informação Geográfica, outros aprendem de forma autônoma e assim se dedicam a este campo de trabalho.

- Os artigos da Lei n 6.664, a qual disciplina a profissão de geógrafo, que amparam legalmente a elaboração desta atividade são, sobretudo, estes listados na sequência:

a) na delimitação e caracterização de regiões, sub-regiões geográficas naturais e zonas geoeconômicas, para fins de planejamento e organização físico-espacial;

c) na interpretação das condições hidrológicas das bacias fluviais;

d) no zoneamento geo-humano, com vistas aos planejamentos geral e regional;

e) na pesquisa de mercado e intercâmbio comercial em escala regional e interregional;

f) na caracterização ecológica e etológica da paisagem geográfica e problemas conexos;

g) na política de povoamento, migração interna, imigração e colonização de regiões novas ou de revalorização de regiões de velho povoamento;

h) no estudo físico-cultural dos setores geoeconômicos destinados ao planejamento da produção;

i) na estruturação ou reestruturação dos sistemas de circulação;

j) no estudo e planejamento das bases físicas e geoeconômicas dos núcleos urbanos e rurais; 
I) no aproveitamento, desenvolvimento e preservação dos recursos naturais;

$\mathrm{m})$ no levantamento e mapeamento destinados à solução dos problemas regionais;

n) na divisão administrativa da União, dos Estados, dos Territórios e dos Municípios.

- Os conceitos e as habilidades técnicas que se relacionam com as disciplinas de apoio acima mencionadas são, sobretudo, as do eixo cartográfico e atualmente do campo da informática, possibilitando ao geógrafo, que conhece a base teórica da cartografia na universidade, se utilizar de softwares de maneira mais abrangente, aliando teoria e prática.

Nos aspectos técnicos, as ferramentas de microinformática, sensoriamento remoto e cartografia, são aplicadas por meio de programas específicos, como o Spring, Ilwis, ArcGis, Auto Desk Map, entre tantos outros, alguns já utilizados em algumas disciplinas do curso de Geografia.

Muitas vezes, a confecção dos mapas, se faz a partir de análise e fotointerpretação de fotografias aéreas ou imagem de satélite, com o posterior reconhecimento de campo, para verificação e atualização das informações constatadas em gabinete, pois em alguns casos, não há imagens atuais disponíveis, exigindo esta atualização em loco. 


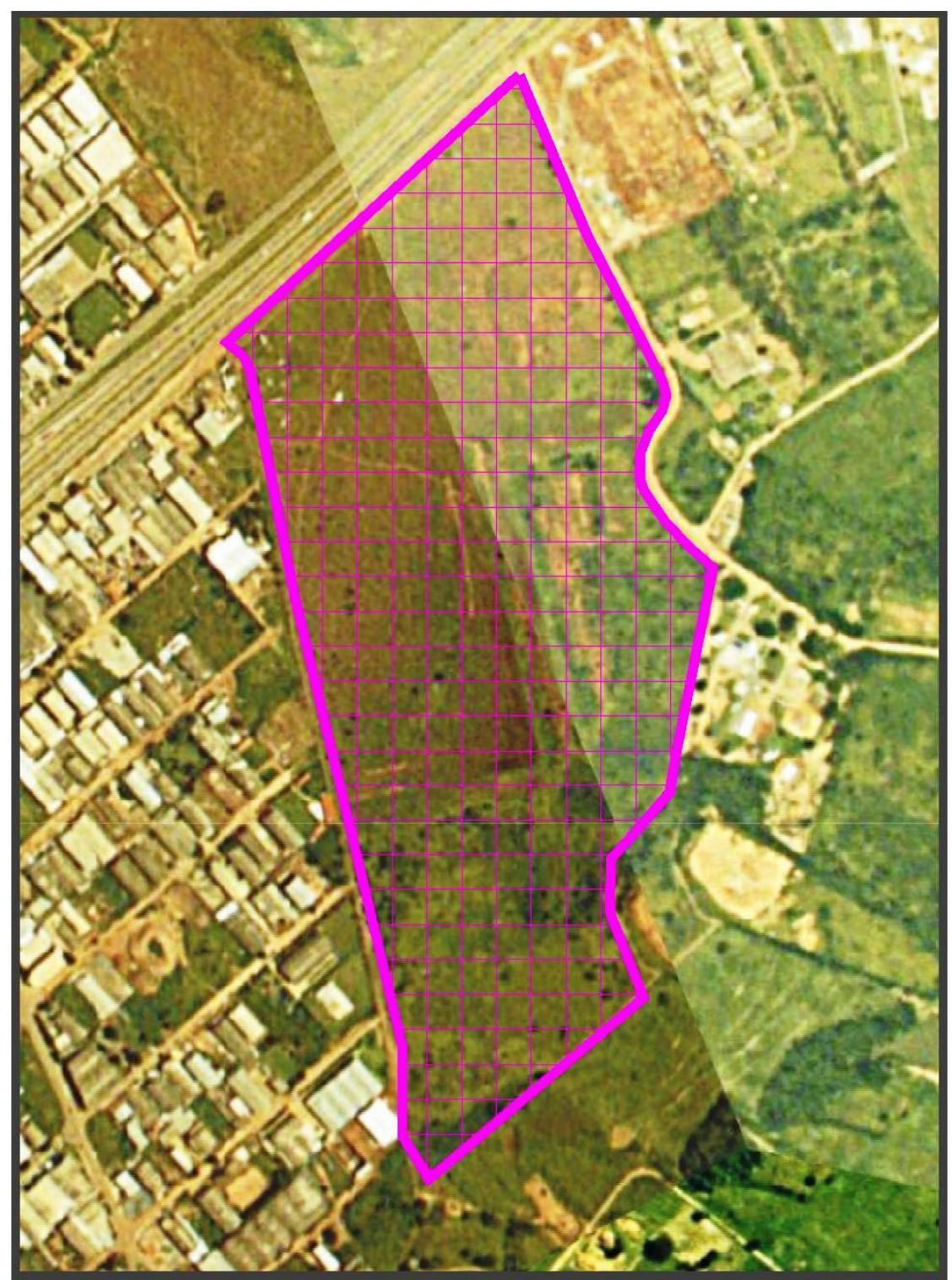

Figura 2.1.1.1. Imagem Aérea Legenda
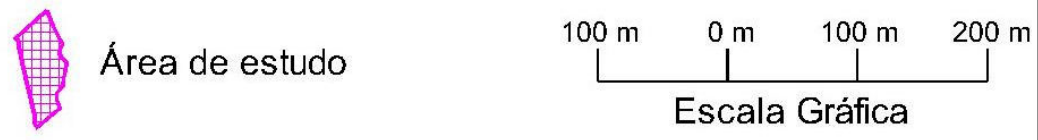

Figura 3.11-1: Exemplo de delimitação de área de estudo sobre a foto aérea. 


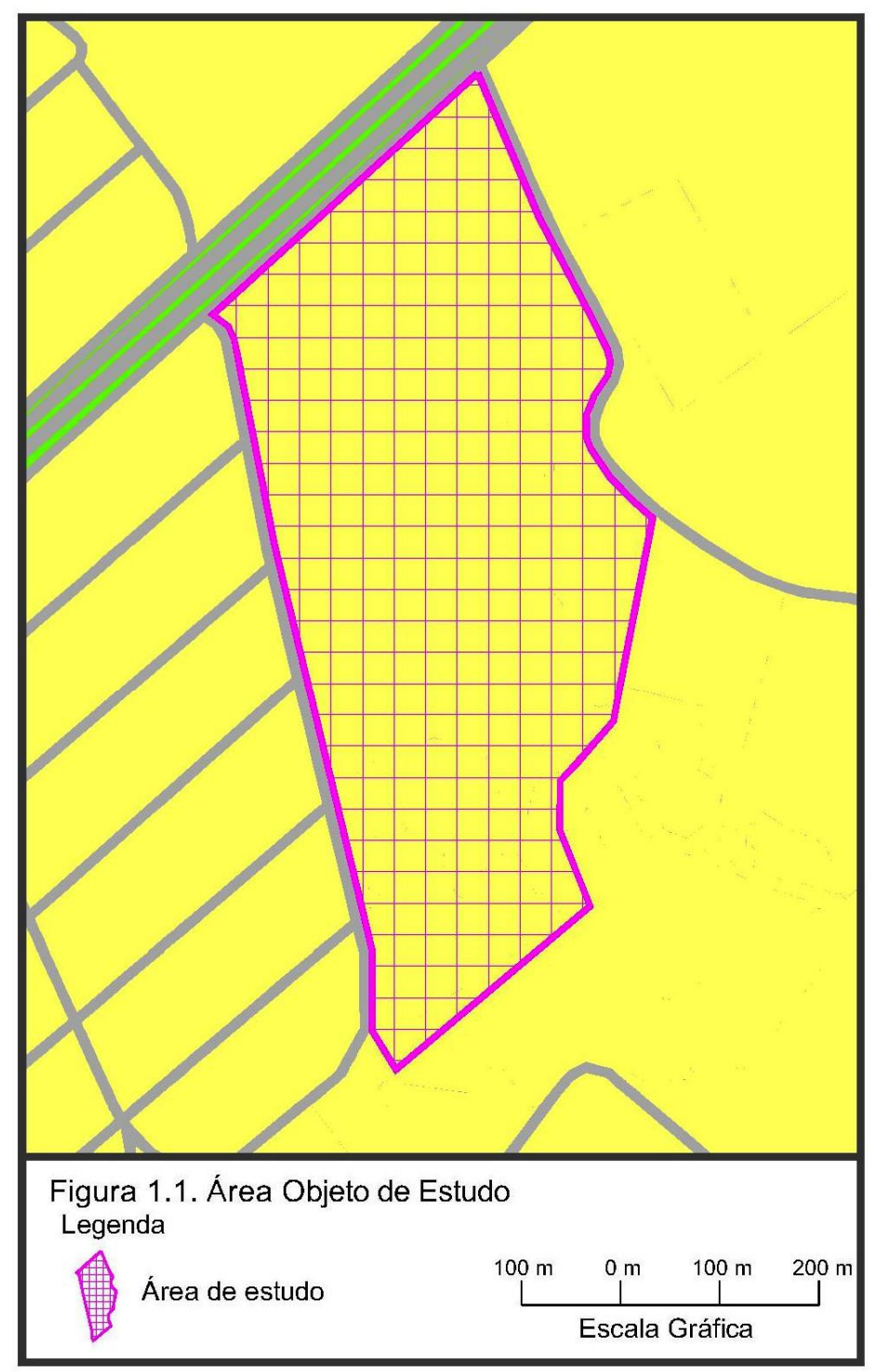

Mapa 3.11-2: Exemplo de mapa de localização elaborado para o estudo de impacto ambiental, mesma área da foto aérea anteriormente apresentada.

\subsection{Coordenação de Estudos de Impacto Ambiental}

O geógrafo, por ter em sua grade curricular, uma gama de disciplinas diversificadas, as quais perpassam pelos aspectos físico, biótico e antrópico, torna-se um profissional diferenciado e pode contribuir de forma consistente à coordenação dos estudos de impacto ambiental, já que, ao longo de sua formação, o estudo de diversos temas fortalece a análise integrada. 
O coordenador tem a função principal de dar coesão e consistência aos relatórios que, em conjunto, formarão o EIA, relatórios estes elaborados por profissionais de formações diversificadas, com sua linguagem igualmente variada. Dependendo do porte do trabalho e de seu impacto ao meio ambiente, pode haver 10, 20, 30 diferentes técnicos, ou mais, atuando no EIA; são engenheiros civis, agrônomos, florestais; biólogos, geólogos e em alguns, geógrafos, arquitetos, engenheiros químicos, ambientais, ecólogos, gestores ambientais, tecnólogos, desenhistas etc.

A divisão de relatórios para os profissionais busca que cada um seja elaborado da melhor forma possível, no entanto para o fechamento do EIA deve-se levar em consideração que:

....a setorização da natureza foi feita pelo homem pela dificuldade de entendê-la integralmente. As relações dos diversos componentes da natureza são na realidade de interdependência e uma não existe sem a outra. Não se pode pensar em geologia sem entender a geomorfologia e vice-versa, mas também não se conhece a tipologia e gênese de um determinado solo sem que se conheça a forma do relevo a ele associado e à litologia a partir da qual evoluiu. Por outro lado, fica impossível se conhecer a dinâmica geomórfica e pedológica sem que se conheçam as características climáticas e assim sucessivamente. (Ross, 1990, p. 8)

A reunião dos dados sobre o projeto a ser implantado, juntamente com os estudos que formarão o EIA e a padronização da linguagem constante nestes, tornam-se as tarefas a serem executadas pelo coordenador, que acaba por ser o profissional que terá noção total do projeto a ser licenciado e de seu EIA.

Cabe também ao coordenador, a elaboração de alguns capítulos ou textos de articulação entre os diferentes relatórios, bem como a inclusão de dados necessários à qualidade do estudo e que podem não ter sido abordados pelos demais técnicos envolvidos no trabalho, delegando à coordenação uma atenção redobrada para que não faltem informações importantes ao pleno atendimento da legislação ambiental vigente, bem como de alguns roteiros pré-estabelecidos para determinados projetos, disponibilizados, por exemplo, pela Secretaria Estadual de Meio Ambiente.

Em projetos licenciados pelo EIA-RIMA, há necessidade de apresentação do mesmo em audiências públicas no município em que se encontra o empreendimento e na maioria das vezes, quem faz a apresentação é o coordenador do trabalho, uma vez 
que este é o profissional que acabou por ter um maior envolvimento com a totalidade do estudo.

Há também, diversas pequenas tarefas executadas pelo coordenador, como, dependendo do projeto, a elaboração de alguns dos estudos a serem inseridos no EIA, a contratação dos profissionais, quando da necessidade da busca fora da empresa contratada para sua elaboração, a apresentação do projeto para todos os técnicos, a formatação / diagramação dos textos, mapas, quadros, figuras etc.; o intercâmbio entre a empresa que projeta o empreendimento, o empreendedor e os técnicos do EIA, pois, por vezes, há 03 ou 04 empresas diferentes envolvidas no licenciamento.

Para que o geógrafo ou qualquer outro profissional assuma a coordenação de um EIA-RIMA, RAP, EAS ou outro trabalho, não basta que ele possua uma boa formação cientifica, técnica, critica e teórica; há também a necessidade de experiência profissional na área, uma vez que envolvem diversas atividades, além de uma grande responsabilidade.

De certa forma, todas as disciplinas do curso de Geografia preparam o profissional para esta atividade, uma vez que a grade curricular do geógrafo abrange disciplinas que vão desde Cartografia Temática, Sensoriamento Remoto, Aerofotogeografia, Cartografia Ambiental, Teoria e Método I e II, Teoria Geográfica da Paisagem, Teoria da Região e da Regionalização, Biogeografia, Hidrografia, Geografia Urbana, Geografia Agrária, Geomorfologia, Pedologia, Recursos Naturais, Microinformática Instrumental em Geografia, Introdução aos Sistemas de Informações Geográficas, Geografias Regionais do Sul, Sudeste, Nordeste, Amazônia, do Estado de São Paulo, Geografia Política, Climatologia I e II, Geografia Econômica, Planejamento, Técnicas de Campo e Laboratório, entre outras; todas que de alguma maneira contribuem nos conhecimentos acerca dos meios físico, biótico e antrópico, alvos de relatório dentro dos EIAs; não há outro curso superior com a variedade e diversidade de abordagens, tão propícias aos EIAs.

A abordagem teórica, conceitual e técnica de tão variadas disciplinas, com seu amplo espectro de possibilidades favorecem uma visão integradora, que por sua vez contribui na capacidade de coordenação relegada, neste caso, ao geógrafo. 
- Os artigos da Lei $n^{\circ} 6.664$, a qual disciplina a profissão de geógrafo, que o amparam legalmente na coordenação do EIA são, sobretudo, estes listados na seqüência:

I - reconhecimentos, levantamentos, estudos e pesquisas de caráter físicogeográfico, biogeográfico, antropogeográfico e geoeconômico e as realizadas nos campos gerais e especiais da geografia, que se fizerem necessárias:

a) na delimitação e caracterização de regiões, sub-regiões geográficas naturais e zonas geoeconômicas, para fins de planejamento e organização físico-espacial;

b) no equacionamento e solução, em escala nacional, regional ou local, de problemas atinentes aos recursos naturais do País;

c) na interpretação das condições hidrológicas das bacias fluviais;

d) no zoneamento geo-humano, com vistas aos planejamentos geral e regional;

e) na pesquisa de mercado e intercâmbio comercial em escala regional e interregional;

f) na caracterização ecológica e etológica da paisagem geográfica e problemas conexos;

g) na política de povoamento, migração interna, imigração e colonização de regiões novas ou de revalorização de regiões de velho povoamento;

h) no estudo físico-cultural dos setores geoeconômicos destinados ao planejamento da produção;

i) na estruturação ou reestruturação dos sistemas de circulação;

j) no estudo e planejamento das bases físicas e geoeconômicas dos núcleos urbanos e rurais;

I) no aproveitamento, desenvolvimento e preservação dos recursos naturais;

$\mathrm{m})$ no levantamento e mapeamento destinados à solução dos problemas regionais;

n) na divisão administrativa da União, dos Estados, dos Territórios e dos Municípios.

- Os conceitos e as habilidades técnicas que se relacionam com as disciplinas acima mencionadas são todos os particulares de cada uma delas, que de certa forma contribuem na formação do geógrafo e que o ampara em todos os itens de sua legislação a coordenar um estudo de impacto ambiental.

\section{TRABALHOS DE CAMPO}

Os trabalhos de campo conformam-se em um excelente suporte para a elaboração dos diagnósticos ambientais, bem como para a mensuração dos impactos a serem causados pelo novo empreendimento, possibilitando também a proposição de medidas mitigadoras e compensatórias. 
Sob uma base teórica e metodológica própria do profissional envolvido na elaboração do EIA, neste caso, o geógrafo, o trabalho de campo irá permitir que se determine a melhor abordagem a ser dada à área de estudo, sua paisagem, região e transformação, por vezes, de uma primeira natureza, para uma segunda animada pelo homem, o próprio espaço geográfico, sobreposto por novas formas, conteúdos e rugosidades.

Os "trabalhos de campo frequentemente são um meio de coletar previamente dados não existentes e necessários para a análise dos impactos." (Sánchez, 2008, p. 163)

Outrossim, após a exposição dos estudos existentes dentro dos EIAs, além da cartografia / geoprocessamento e coordenação, passíveis de serem elaborados pelos geógrafos, seguem agora, alguns exemplos práticos de projetos sendo licenciados por este autor e como se deu a inserção deste geógrafo, atuando neste campo profissional.

Uma vez, que se referem a projetos em andamento, ou seja, que ainda não se tornaram públicos, pois o órgão ambiental competente ainda não emitiu a Licença Prévia (LP), estes, serão apresentados, porém, sem informar em qual município se localizam, por serem ainda confidenciais, tal qual explicado.

Cabe lembrar, que todos EIAs são elaborados por equipes técnicas multidisciplinares, portanto, a escolha dos quatro exemplos a seguir, se deu por dois motivos principais: primeiro, por serem empreendimentos distintos; segundo, este autor, elaborou estudos, às vezes, diferentes para cada empreendimento, possibilitando assim, uma gama maior de abordagens.

Por último, vale informar que o quarto exemplo foi inserido, por se tratar de um licenciamento diferenciado, abordando a regularização de uma área autuada pela polícia ambiental, conforme será visto na sequência. Trata-se também, do único projeto de pequeno porte, portanto, executado por apenas um profissional, neste caso, o próprio autor.

\subsection{Mineração}


Este licenciamento foi o único em minha carreira profissional, em que elaborei pelo menos um relatório de cada meio: físico, biótico e antrópico, embora não tenha assinado todos eles, uma vez, que, mesmo que não seja ilegal, não é recomendável que, um profissional recolha ARTs de tão variados estudos. Os órgãos ambientais licenciadores pedem que os estudos sejam elaborados por equipes técnicas multidisciplinares.

Por se tratar de um empreendedor (minerador) que exigiu contenção de gastos, e que se formasse uma equipe pequena de técnicos para que não se elevassem os custos com deslocamentos, hospedagens e refeições; elaboramos o Plano de Recuperação de Áreas Degradadas (PRAD), com apenas três profissionais: um geólogo e dois geógrafos.

O geólogo que coordenou o trabalho, também se incumbiu da elaboração dos relatórios de: geologia, geomorfologia, pedologia e hidrologia, todos plenamente passíveis de serem elaborados por ele na divisão de tarefas, uma vez que para os demais relatórios, ele não teria capacidade técnica e amparo legal.

Ao colega geógrafo, coube a elaboração dos mapas a serem inseridos no PRAD, referentes a todos os relatórios que necessitassem de tal figura, além da colaboração no relatório de Vegetação.

A este autor, o segundo geógrafo da equipe, coube a elaboração dos estudos de clima e qualidade do ar (meio físico), uso e ocupação do solo (meio antrópico), relatório de vegetação e sua fauna associada, do meio biótico.

A formação de geógrafo contribuiu com o olhar multidisciplinar, sem o qual, jamais um profissional de qualquer área elaboraria relatórios de distintas áreas do conhecimento, neste caso, meios físico, biótico e antrópico. É evidente também, que a experiência profissional e vivência nesta área facilitam essas tarefas. Por outro lado, vale informar que, mesmo com mais de 06 anos de experiência em licenciamento ambiental, tratou-se do primeiro PRAD em que participei, portanto, embora tenha esta vivência, um trabalho nunca é igual ao outro, e a visão do geógrafo permite uma maior adaptação para este campo profissional, visão esta, 
oriunda do aporte teórico, científico e técnico de grande abrangência e ao mesmo tempo integradora.

Sob os aspectos legais, conforme mencionado em cada relatório dos itens anteriores, sem dúvida há amparo legal para a atuação, também, nos PRADs, ressaltando que neste tipo de estudo é essencial a presença de um geólogo ou de um engenheiro de minas, que possuem capacidade técnica e legal para determinadas abordagens, não cabíveis ao geógrafo por sua simples formação.

O amparo teórico da Geografia contribui de maneiras genéricas e específicas: as primeiras se referem a questões relacionadas ao conceito de paisagem e sua reconformação no caso dos PRADs, que visam, sobretudo, devolver ao ambiente, um status o mais próximo do anterior à atividade mineira; neste aspecto entram também conceitos de região e a importância de readaptar a área impactada de acordo com o que se vê na região de estudo, seja ela sob o enfoque municipal, distrital, de bacia hidrográfica, ou sob o simples enfoque de uma região rural, em que predominam chácaras de moradia e pequenas plantações em parte e grandes latifúndios em outra.

Do ponto de vista técnico, a formação do geógrafo redunda na apreensão do espaço como um "conjunto indissociável de sistemas de objetos e de sistemas de ações" (Santos, 2002). Esse enfoque permite que, tecnicamente, o geógrafo utilize ferramentas da Geografia física e humana para apreender o espaço em sua totalidade, sejam ferramentas do sensoriamento remoto, sejam métodos biogeográficos da compreensão da vegetação, ou medições de temperatura, pressão e umidade do ar, relacionadas à climatologia, num espectro amplo de possibilidades técnicas trazidas na grade curricular do bacharelado de Geografia.

Para este PRAD especificamente, o que chamou a atenção, sob o olhar crítico do geógrafo, foi a quantidade de água utilizada no processo de lavra do minério deste empreendimento, que embora fosse com o objetivo de recuperar algumas áreas, iria expandir para outras, e a quantidade de água gasta no desmonte hidráulico do minério é algo inacreditável, sem mensuração possível, uma vez que estes dados não podiam ser divulgados, ainda com o agravante de se tratar de uma região 
(conjunto de municípios com características físicas similares) com problemas de escassez de água.

Não houve dificuldades na elaboração dos relatórios; evidentemente que se trata de um trabalho árduo e dispendioso em termos de dedicação, com leituras específicas sobre a região de estudo, sobretudo, por se tratar de vegetação que, neste caso era de caatinga, uma novidade para os três técnicos envolvidos no trabalho.

A atividade mineira é extremamente impactante, uma área minerada e ainda não reabilitada para outros usos, traz um grande impacto visual, pois parece que o local não será mais passível de qualquer outro uso social. Porém, no PRAD, se propõe a mitigação dos impactos, trazendo às antigas áreas, um novo status e a possibilidade de outras finalidades: áreas de lazer, de agricultura e de moradia - dependendo do tipo de reabilitação empreendida.

É uma atividade que gera bastante emprego e, em certos municípios, trata-se do maior empregador, trazendo por um lado benefícios às famílias da cidade, por outro, a modificação de sua paisagem, ora com possibilidade de reabilitação, ora com modificações irreversíveis.

Evidentemente que o grande beneficiado com a mineração, em primeiro lugar é o empresário proprietário do estabelecimento; em segundo lugar, quando em propriedades alheias, os arrendatários das terras a serem lavradas; depois, os funcionários, com geração de emprego e renda e, por fim, a própria sociedade que se beneficia do minério extraído desses empreendimentos sem os quais a vida como é hoje, e neste caso específico, vida da sociedade brasileira, com exigências de consumo específicas, relacionadas ao estágio de consumo da sociedade contemporânea. 

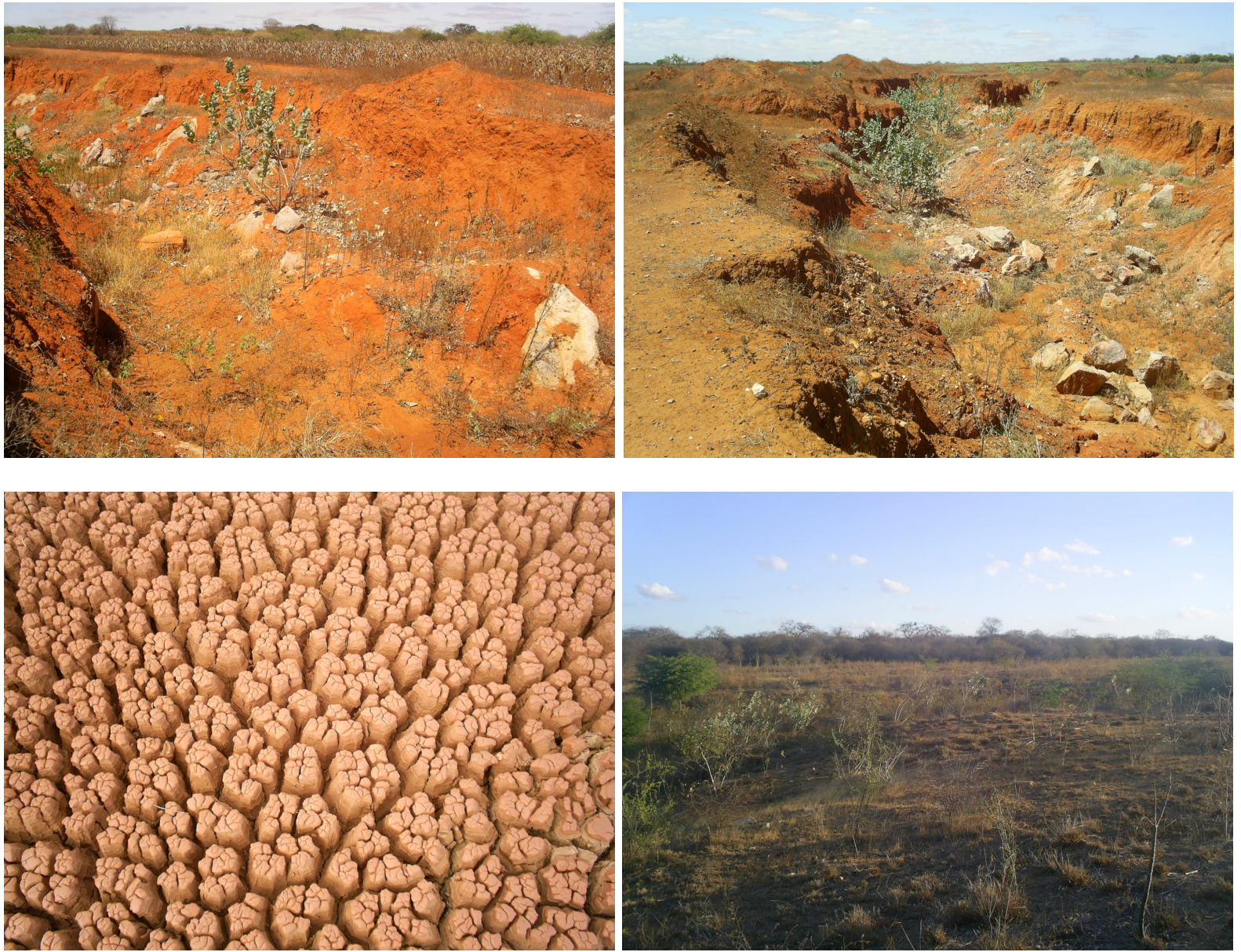

Figuras 4.1-1 a 4: Em sentido horário, a partir de cima, a esquerda: Cava de mineração a ser recuperada, após a análise do PRAD, pelos órgãos ambientais competentes. Outra cava de mineração. Bacia de rejeitos da atividade mineira. E por último, área de antiga cava já recuperada e com o plantio de algumas mudas nativas.

Um dos problemas encontrados, para a execução da reabilitação de áreas de mineração se dá em terras arrendadas, uma vez que certos proprietários, por exemplo, não aceitam que sejam plantadas mudas de árvores nativas em seus terrenos, por quererem aproveitar suas terras para outros usos sociais, que não o de preservação.

\subsection{Aterro Sanitário}


Para este EIA-RIMA, que ainda nem foi protocolado no órgão ambiental competente, portanto de extrema confidencialidade, fui contratado para responder pelo meio antrópico, elaborando os relatórios de Uso e Ocupação do Solo, Socioeconomia e Sistema Viário, em um curto prazo de tempo, o que me levou a contratar um ajudante, também geógrafo, amigo de longa data.

Com mais experiência que o colega, fiquei na coordenação do meio antrópico, com a elaboração dos relatórios de Uso e Ocupação do Solo e Socioeconomia e na supervisão e correção em seu relatório de Sistema Viário.

Geralmente, quando uma consultoria ambiental contrata profissionais fora de sua equipe interna há dois motivos distintos: o primeiro é que podem exigir um prazo curtíssimo, uma vez que pagarão por isso, e o consultor tem que entregar no prazo estabelecido; outro motivo é que certas consultorias, não possuem um quadro grande de técnicos, buscando-os somente quando há necessidade de realizar algum trabalho.

Para este EIA-RIMA, a situação era dúbia, ou seja, prazo exíguo e possivelmente, não havia técnicos com experiência nestes relatórios.

A formação de geógrafo contribui com a dimensão multidisciplinar, a qual prepara o profissional para lidar com situações variadas, buscando soluções, mesmo que com certos obstáculos, fato que deve estar relacionado à capacidade de pesquisador desenvolvida durante a graduação e em outros, na própria sequência acadêmica, na pós-graduação.

Como dito anteriormente, somente a formação não basta para atuar no licenciamento ambiental, sendo necessária experiência para se atingir uma capacidade de responder a diversos tipos de trabalhos em diversas escalas de análise.

Sob os aspectos legais, conforme já mencionado, em cada relatório apresentado nos itens anteriores desta dissertação, sem dúvida há amparo legal para a atuação, também, nos estudos antrópicos, uma vez que a sociedade é objeto de estudo da Geografia, assim como a natureza, e a própria relação da sociedade com a natureza. 
O amparo teórico da Geografia contribui de maneiras genéricas e específicas; as primeiras referem-se a questões relacionadas ao conceito de paisagem atual (natural, em termos, pois já é modificada por ações humanas pretéritas) para o diagnóstico da área, para uma paisagem antropizada (na previsão dos impactos), até uma possível reconformação ao final das atividades do aterro, com o recobrimento por algum tipo de vegetação rasteira, devolvendo a paisagem ainda antropizada, uma verossimilhança a de outrora.

Conceitos de região são trazidos a tona em estudos antrópicos, sobretudo, para este tipo de empreendimento que elege uma região delimitada por um raio de $50 \mathrm{~km}$ de atuação, de onde se pretende receber os resíduos sólidos domésticos, além de materiais inertes, oriundos de demolições e sobras da construção civil. A região aqui foi dada pelo empreendedor - $50 \mathrm{~km}$ de raio e ponto final.

Sob o ponto de vista técnico, a formação do geógrafo, nos estudos do meio antrópico e, sobretudo em uso e ocupação do solo e socioeconomia, permite analisar a localidade sob o enfoque da Geografia Urbana, com os conceitos de expropriação dos pobres, ou sob o enfoque de o capital prevalecer frente a possíveis restrições da população afetada pelo empreendimento; as ferramentas de microinformática e fotointerpretação permitem o reconhecimento do todo e das partes, numa análise local e regional.

A questão espacial também se faz presente no momento em que um empreendimento deste porte não pode ficar próximo a áreas urbanizadas, para não causar determinados incômodos, mas também não pode se distanciar delas, para não inviabilizar, pela distância seu "mercado consumidor", além da necessidade da mão-de-obra para o funcionamento do mesmo, assim a questão do lugar se torna preponderante na análise antrópica de um aterro sanitário, com todos os benefícios e problemas trazidos em seu bojo.

Sob o ponto de vista crítico, a formação do geógrafo, nos estudos do meio antrópico e, sobretudo em uso e ocupação do solo e socioeconomia, não se restringe a verificar a população das áreas de influência do empreendimento como uma categoria de uso, ou um número determinado de moradores, mas sim, uma análise 
integrada que possibilite verificar o real incômodo trazido por um empreendimento desta magnitude a uma região, tal qual a escolhida pelos empresários.

Quanto ao estudo do sistema viário local e regional, este se mostrou bastante forte para receber uma nova demanda de tráfego oriunda da implantação do aterro sanitário, constatação advinda de contagem de veículos na via de acesso ao local e também por meio de dados oficiais obtidos de algumas vias de acesso, junto aos responsáveis pela manutenção das mesmas.

Dada a vivência deste autor, não houve dificuldades na elaboração dos relatórios, embora tenha havido um desgaste bastante grande, por conta dos prazos exíguos de entrega, todo trabalho agrega um novo conhecimento, mesmo que se trate de um empreendimento que já se tenha trabalhado, sempre há muito a aprender e aplicar nos relatórios.

A implantação de um aterro sanitário é impactante, ninguém deseja ter um destes próximo de suas residências. Por outro lado, se ninguém deixa de produzir lixo, está posto o embate em se licenciar este tipo de empreendimento, ele é extremamente necessário e alguma população local ou regional irá sair prejudicada, não há como negar. Mas, basta ver o que ocorreu em Nápoles - Itália no início de 2008, com o esgotamento dos aterros e as ruas cobertas por lixos em grande parte da cidade.

O ideal seria a reciclagem de $100 \%$ dos resíduos produzidos, mas uma vez que isto ainda está distante de se concretizar, o aterro sanitário conforma-se em uma boa opção de destinação dos lixos urbanos, uma vez que é preparado tecnologicamente para causar o mínimo de danos possíveis ao local de implantação, aos seus funcionários e à população localizada em suas imediações.

Cabe mencionar que o terreno será escavado para posteriormente recobrirem a base com uma "manta" de PVC, para depois, utilizar-se do local, controlando os gases e o chorume gerado pelos resíduos, tal qual se faz em modernos aterros no Brasil e no mundo. Não será necessária também, a supressão de exemplares arbóreos significativos, outro fator positivo.

$\mathrm{Na}$ verdade, todos os empreendimentos acarretam em impactos positivos e negativos, o ideal seria que os primeiros prevalecessem sobre os segundos. 


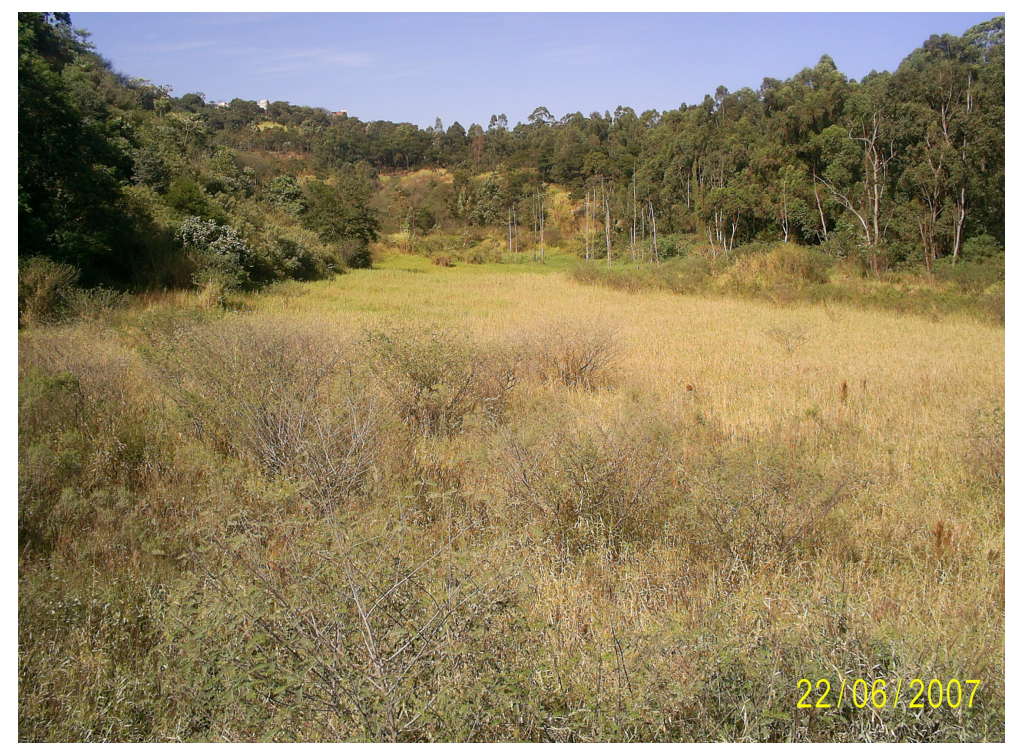

Figura 4.2-1: Vista parcial do terreno, objeto de estudo, onde será implantado o aterro sanitário.

Somente neste caso específico, trata-se de uma figura ilustrativa, que não se refere à área verdadeira do aterro sanitário, uma vez que não foi autorizado o uso da mesma.

\subsection{Loteamento}

Neste licenciamento coube a este autor a elaboração dos quatro estudos do meio antrópico: Uso e Ocupação do Solo, Socioeconomia, Resíduos Sólidos e Sistema Viário; além do relatório constante do meio físico, Hidrologia, que no ElA, fora nomeado de Recursos Hídricos Superficiais.

Para loteamentos residenciais (como era este) e comerciais, o estudo do meio antrópico, muitas vezes, é o mais importante no cômputo geral do EIA uma vez que, dependendo da população prevista para o novo empreendimento, o impacto pode ser de difícil absorção para o município em que se localiza o mesmo.

Neste caso especificamente, o impacto era de mensuração dúbia, por se tratar de um empreendimento localizado no litoral, numa cidade com população fixa de cerca de 30 mil habitantes, mas que em feriados, finais de semana e férias, chegava a abrigar até mais de 200 mil pessoas, conforme dados obtidos junto à prefeitura. 
Uma vez que o novo loteamento previa uma população adicionada de cerca de 3.000 pessoas, o impacto era significante analisando-se a população fixa, com um acréscimo de $10 \%$ da mesma, mas sob a análise do fator "veraneio", o impacto era muito reduzido.

Por esses motivos, o estudo do meio antrópico exigiu uma abordagem bastante cautelosa, em que a metodologia de região teve que ser ampliada, a partir de fenômenos de concentração humana, abrangendo macrorregiões metropolitanas, que poderiam se beneficiar do futuro empreendimento, sendo, portanto, consideradas áreas de influência direta e indireta do empreendimento.

A coordenação do EIA-RIMA não estava sob minha responsabilidade; atuei apenas como consultor externo na elaboração dos relatórios acima citados.

O relatório de Recursos Hídricos Superficiais poderá impedir a implantação do loteamento, ou exigir uma reordenação da área prevista para os lotes, áreas de lazer e arruamento, uma vez, que um curso d'água identificado no terreno, na elaboração do trabalho, era visto como uma cava de drenagem que eles pretendiam recobrir. Este EIA, está em análise, por parte do órgão ambiental competente há mais de 18 meses, portanto, acredito que justamente a hidrografia possa ter complicado a aprovação, tal qual estava previsto.

A formação de geógrafo contribuiu com a visão integradora para a realização dos estudos mencionados acima, permitindo, diagnosticar os impactos previstos no âmbito da paisagem local e também na apreensão regional, devido ao alcance de empreendimento litorâneo, por vezes, direcionados a segunda residência.

Sob os aspectos legais, conforme mencionado em cada relatório dos itens anteriores, sem dúvida, há amparo legal para a atuação nos estudos elaborados para este EIA.

O amparo teórico da Geografia contribui de duas maneiras: a local, que se refere à paisagem natural, que para a implantação do empreendimento se transformaria em antrópica, e a regional, com o nível de alcance dos impactos adicionados por um empreendimento litorâneo. 
Sob o ponto de vista técnico, a formação do geógrafo, nos estudos do meio antrópico, permite analisar a localidade sob o enfoque da Geografia Urbana, com a apropriação dos lugares pela população mais abastada, por se tratar de um empreendimento de frente para a praia, em detrimento das residências localizadas a mais de 1 km da mesma, auto-construídas em áreas impróprias e insalubres.

As ferramentas de microinformática e fotointerpretação permitiram o reconhecimento da área e de seu entorno, de forma a diagnosticar os impactos deste empreendimento naquele local e até de prognosticar de onde sairá a mão-de-obra doméstica (caseiros, jardineiros, faxineiros, porteiros, etc.) que trabalhará no local futuramente, se as licenças forem obtidas.

A compreensão da hidrografia local se deu pela interpretação de cartas e fotografias aéreas recentes e de décadas anteriores, bem como pelo trabalho de campo para confirmação da existência real do curso d'água, e não de uma vala de drenagem, como acreditavam os empreendedores, fato que não os deixou nada contentes.

Sob o ponto de vista crítico, a formação do geógrafo, para os relatórios elaborados neste EIA, permitiram apreender a complexidade de se licenciar um empreendimento de alto padrão, de frente para a praia e ver num raio de $1 \mathrm{~km}$, pequenas moradias auto-construídas e até barracos, uma desigualdade social latente em tão pequena distância. A conversa com os moradores dessas comunidades permitiu perceber que muitos deles, trabalham nos loteamentos e condomínios de alto padrão próximos de suas casas, portanto, não se importando em morar precariamente, uma vez que tinham seu sustento garantido.

Não houve dificuldades para a realização dos relatórios do meio antrópico, o mais complicado foi o hidrológico, uma vez que tudo levava a crer em haver uma vala de drenagem artificial, exigindo um estudo bastante aprofundado, histórico e até a confirmação de seu status por outros colegas de profissão. 

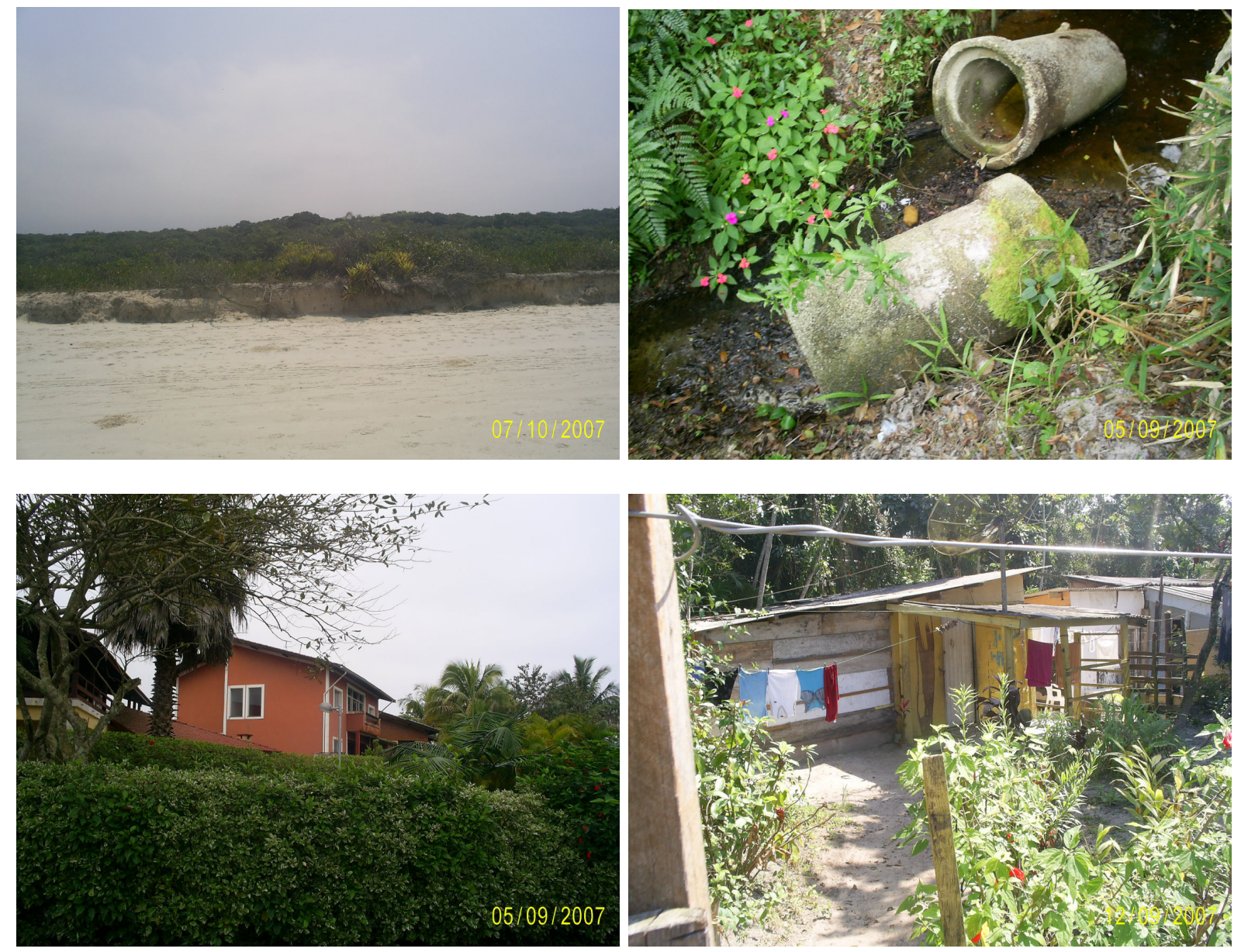

Figuras 4.3-1 a 4: Em sentido horário, a partir de cima, a esquerda: área em processo de licenciamento. Curso d'água natural, receptor de esgotos e drenagem de chuvas. Exemplo de residência de alto padrão localizada próximo a área do empreendimento. Residências auto-construídas e barracos existentes a cerca de $1 \mathrm{~km}$ da área de alto padrão.

Há certos municípios, em que o contraste existente, entre as condições de habitação e renda dos moradores fixos e dos proprietários de segundas residências, é extremamente marcado, causando um grande desconforto em se realizar determinados licenciamentos ambientais.

\subsection{Regularização Ambiental de Propriedade}

Este tipo de licenciamento, que embora não seja um estudo de impacto ambiental, propriamente dito, trata da regularização ambiental de uma propriedade, que neste caso, refere-se a uma indústria, com suas áreas industriais, galpões, estacionamentos, armazéns, refeitório, etc. 
Esta indústria que possui um grande terreno, do qual, cerca de $80 \%$ tem algum uso interno para o pleno funcionamento da empresa, possuía uma área livre aos fundos - cerca de $10 \%$ do terreno total, que acaba em uma vertente bastante íngreme.

No intuito de aumentar esta área de 10\% livre, para cerca de 15\%, o proprietário, aparentemente desconhecendo as leis ambientais, aterrou parte desta vertente, para que aumentasse a área no patamar de cima, de forma que esta nova área pudesse ser utilizada para manobra de caminhões, porém com este aterro, alguns exemplares arbóreos nativos foram soterrados.

Acontece que, algum vizinho da empresa, ou mesmo algum funcionário, nunca se sabe, denunciou o fato à policia ambiental, a qual compareceu ao local e emitiu um advertência com o seguinte conteúdo "Explorar mediante supressão com aterro, formação sucessora de vegetação nativa em estágio inicial de regeneração, correspondente a 0,08ha sem autorização prévia do órgão ambiental competente.....

Esta advertência, fez com que a empresa procurasse uma consultoria ambiental para solucionar seu problema, para que isso não se transformasse em punições maiores, assim, fui contratado para resolver tal questão.

Apresentei então, após trabalho de campo na propriedade, um projeto técnico de reparação de danos ambientais que incluía algumas etapas.

As atividades desenvolvidas na elaboração do diagnóstico ambiental dessas áreas foram:

- levantamento bibliográfico identificando o Domínio Florestal que a região está inserida e as espécies predominantes.

- levantamento de campo para reconhecimento de cobertura vegetal, identificando os estágios de regeneração em desenvolvimento;

- definição dos limites geográficos e descrição de fitofisionomias principais, ocorrentes na área de estudo, interfaceadas com o grau de alteração existente.

Segundo Ab'Saber (2003), a área em estudo encontra-se inserida no Domínio Morfoclimático dos Mares de Morros (áreas mamelonares tropicais atlânticas 
florestadas). Está incluída na região de ocorrência da Floresta Pluvial Tropical Atlântica, que se inicia junto ao mar, seguindo paralelamente a Leste.

Atualmente, na área de estudo e entorno em termos regionais, observa-se a presença de matas secundárias, incluídas no Sistema Atlântico de Vegetação formado por trechos remanescentes de Mata Atlântica, considerando diferentes tipologias vegetais, associada ao estado de conservação de cada uma delas.

No entorno imediato da área, observa-se baixíssima ocorrência de ambientes florestais, caracterizados principalmente por áreas de reflorestamento homogêneo e reduzidas áreas recobertas por mata secundária, definidas por sua qualificação ambiental em estágios pioneiro e inicial de regeneração natural. Nas áreas de mata secundária, incluem-se as áreas recobertas por mata ciliar, as quais se encontram associadas ao sistema de drenagem natural.

As formações apresentam-se fortemente pressionadas pela ocupação humana implantada na região, balizada por empreendimentos residenciais e industriais. Tal ocupação descaracterizou de forma significativa a composição florística das formações florestais, reduzindo-a a fragmentos isolados e disjuntos, com pouco suporte ecológico para a fauna. Esse quadro de atuação antrópica no nível regional encontra fiel reflexo no entorno da gleba, quando da abordagem deste estudo.

Após estas identificações, propusemos aos proprietários da indústria, a remoção da maior parte do material depositado irregularmente na vertente, sua reconformação topográfica, além do plantio de 140 mudas de exemplares arbóreos nativos da região do empreendimento, trazendo um enorme ganho ambiental à paisagem local, e porque não também, regional, uma vez que a arborização, em médio prazo, trará ganhos paisagísticos ao bairro.

Não só o proprietário da indústria, como também o órgão ambiental competente, aprovou o projeto técnico de reparação de danos ambientais, o qual, atualmente está em fase de implantação; em resumo:

- remoção da maior parte do material depositado irregularmente;

- recuperação da vertente, inclusive com o plantio de gramíneas; 
- plantio de 140 mudas de exemplares arbóreos nativos da região.

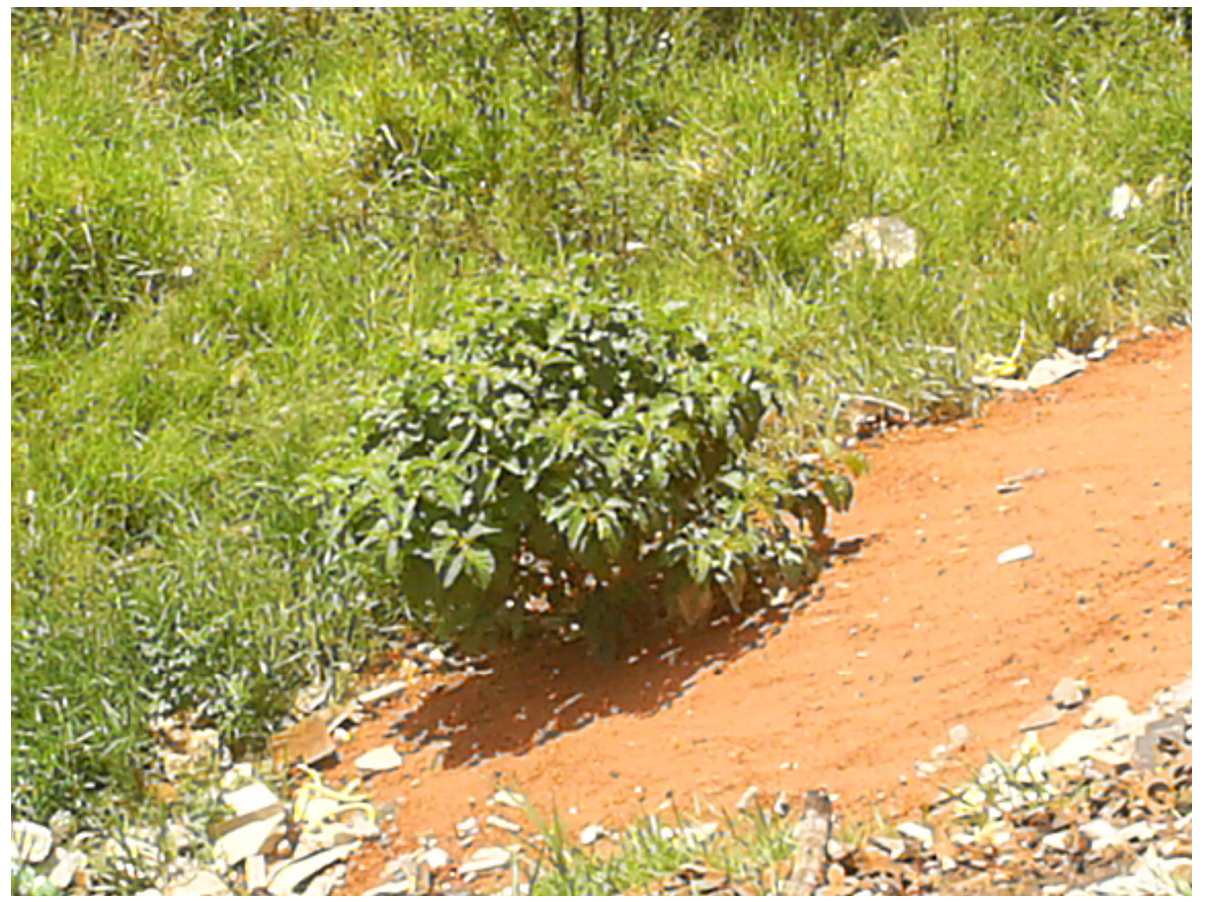

Figura 4.4-1: A direita da fotografia, terra e entulho depositados irregularmente na propriedade, alvo de advertência da polícia ambiental.

O interessante neste trabalho foi que, além de recuperar a área que fora degradada, conseguimos um ganho, que foi o plantio de gramíneas e das 140 mudas já mencionadas.

\section{Impactos Ambientais}

O Conselho Nacional de Meio Ambiente (CONAMA) define impacto ambiental por meio da Resolução 001/86, como sendo:

Qualquer alteração das propriedades físicas, químicas e biológicas do meio ambiente causada por qualquer forma de matéria ou energia resultante das atividades humanas que, direta ou indiretamente, afetem:

- a saúde, a segurança e o bem estar da população

- as atividades sociais e econômicas

- a biota

- as condições estéticas e sanitárias do meio ambiente

- a qualidade dos recursos ambientais 
Embora esta definição seja passível de críticas, acabou-se por se tornar "universal" e por marcar presença em grande parte dos EIAs, servindo de parâmetro para a definição e mensuração dos impactos ambientais.

Por outro lado, dentro dos EIAs, há diversas maneiras de decompor os impactos causados pelo empreendimento em estudo, as equipes que irão elaborá-los definem previamente sua natureza (positivo, negativo), seu nível de intervenção (direto, indireto), temporalidade, abrangência (região, por exemplo), duração, reversibilidade, mitigabilidade, entre outros atributos passíveis de serem abordados.

Como já mencionado, os impactos ambientais diferem bastante de acordo com o tipo de empreendimento, bem como por sua localização, tornando a tarefa da exposição de impactos e medidas mitigadoras e/ou compensatórias bastante dificultada.

Estimar o impacto ambiental de uma atividade que se encontra na fase de projeto é, até certo ponto, um jogo de adivinhação, o qual requer do analista conhecimento científico, visão abrangente, bom senso e objetividade. Requer, sobretudo, a consciência de que os modelos usados, embora ferramentas poderosas na avaliação dos fenômenos, são sempre uma imitação pobre da realidade, e devem ser aplicados, e seus resultados interpretados à luz do estado da arte, e dentro das limitações impostas pelos próprios modelos e pelas condições de contorno do problema. (Silva; Guerra, 2002, p. 236)

Antever impactos ambientais é uma tarefa intelectual científica e requer um bom conhecimento acerca do tipo de empreendimento, de um lado e do local de implantação, de outro. Conhecer bem estas duas vertentes é uma tarefa técnica e científica, para a qual o geógrafo pode contribuir de maneira consistente.

A tarefa de prever impactos assemelha-se com o "fazer ciência", a partir da formulação de modelos e termos gerais que serão impactados naquele lugar, por aquele empreendimento, assim:

O fim específico da ciência é, portanto, a descoberta e a formulação, em termos gerais, das condições sob as quais ocorrem os diversos tipos de acontecimento, servindo os enunciados generalizados dessas condições determinantes como explicações dos fatos correspondentes. Esse objetivo só pode ser atingido identificando ou isolando certas propriedades do assunto estudado e estabelecendo quais os reiterados padrões de dependência que governam a inter-relação daquelas propriedades. (Nagel, 1971, p. 23) 
O "impacto ${ }^{7}$ é de essência indutiva: a partir da certeza que se tem no diagnóstico, pula-se, salta-se para o previsível, perde-se a certeza; mas em ciência é melhor prever sem total certeza, com certa margem de erro, do que nada prever. Quanto melhor a base, mais eficiente será o salto indutivo (a previsão)."

Contudo, para que haja pelo menos um exemplo de impactos ambientais causados por um empreendimento passível de licenciamento a partir de um EIA, a seguir apresenta-se uma tabela com os "principais efeitos e aspectos ambientais induzidos por um empreendimento de mineração" (Sánchez, 2008, p. 203) extraído do livro Avaliação de Impacto Ambiental.

${ }^{7}$ Grifo do prof. Luis Antônio Bittar Venturi (2009) em sua leitura deste trabalho. 
Físicos

Alteração das Características do solo (estrutura, compactação, etc.)

Alteração da topografia local

Alteração da rede hidrográfica

Alteração do regime hidrológico

Aumento da erosão

Aumento de carga de sedimentos nos corpos d'água

Geração de estéreis

Geração de rejeitos

Geração de resíduos sólidos

Dispersão de gases e poeiras

Emissão de ruído

Emissão de vibrações e sobrepressão atmosférica

Dispersão de efluentes líquidos

Rebaixamento ou elevação do nível freático

Subsidência

Aumento dos riscos de escorregamentos de taludes

Bióticos

Interferência sobre processos bióticos nos corpos d'água (e.g. ciclagem de nutrientes)

Eutrofização de corpos d'água

Bioacumulação de poluentes

Fragmentação na cobertura vegetal

Perda de cobertura vegetal

\section{Antrópicos}

Modificação da infra-estrutura de serviços

Deslocamento de assentamentos humanos

Indução de fluxos migratórios

Modificação das formas de uso do solo

Alteração ou destruição de sítios de interesse cultural ou turístico

Aumento de tráfego de veículos

Aumento da demanda de bens e serviços

Aumento da oferta de empregos

Tabela 5-1: principais efeitos e aspectos ambientais induzidos por um empreendimento de mineração. Fonte: Sánchez, 2008, p. 203 (adaptado).

Genericamente, pode-se afirmar que: 
O entendimento das atividades e operações que compõem o projeto, e de suas alternativas, ao lado do reconhecimento das características básicas do ambiente potencialmente afetado, são os pontos de partida para a identificação preliminar dos impactos prováveis (...) (Sánchez, 2008, p. 178)

Não serão apresentadas nesta dissertação, as medidas mitigadoras e/ou compensatórias para os impactos, nem planos de monitoramento e de gestão; em primeiro lugar para não transformar este trabalho em um EIA-RIMA, o qual não se configura em um dos objetivos do mesmo; em segundo, por ser muito difícil a tarefa de apresentá-los, pois, para cada um desses impactos, dependendo da localização e do tipo de empreendimento, seria necessária uma abordagem distinta, derivando, portanto, em infinitas possibilidades de mensuração.

\section{CONCLUSÕES}

Atentando-se para os objetivos desta dissertação, pode-se afirmar que estes foram atingidos, embora as respostas obtidas possam ser diferentes às esperadas antes da realização desta pesquisa.

Primeiramente, buscava-se apontar o potencial de atuação dos geógrafos na elaboração de estudos de impacto ambiental, sistematizando as contribuições que a Geografia proporciona aos seus cientistas, e ao enriquecimento dos estudos, quando elaborados por estes profissionais. Este objetivo foi alcançado, após a exposição da base teórico-conceitual (exemplificada pela: Paisagem, Espaço e Região), e por meio de sua formação teórica, técnica e crítica, bem como no amparo legal de sua profissão, demonstrando o potencial deste profissional, enquanto cientista, mas também enquanto técnico atuante no mercado de trabalho, neste caso na área de licenciamento ambiental.

Percebe-se que, mesmo de forma indireta ou não plenamente consciente, os conceitos e conhecimentos específicos e técnicos ressurgem e contribuem para o trabalho do geógrafo. Do mesmo modo, a postura crítica enfatizada em sua

8 Para maiores esclarecimentos, o livro Avaliação de Impacto Ambiental: conceitos e métodos, SÁNCHEZ, Luis Enrique. Oficina de Textos. São Paulo, 2008, apresenta bastantes exemplos de impactos ambientais. 
formação, em relação à justiça social, qualidade ambiental e ética, é uma característica já incorporada, à qual não é preciso recorrer-se diretamente a ela.

Este objetivo principal foi atingido, também, pela apresentação de todos os relatórios e trabalhos passíveis de serem elaborados pelos geógrafos, apoiando-se na sua formação teórica, técnica e crítica, apreendida durante a graduação; seja por meio das disciplinas curriculares, na variedade de enfoques propiciadas pela diversidade de temas; seja pelas particularidades de cada professor, não só na disciplina que leciona, mas na maneira crítica de expor-se aos alunos. O amparo legal das atribuições profissionais que permitem a confecção desses relatórios foi obtida junto ao CREA e AGB, por meio da lei que disciplina a profissão de geógrafo.

Quanto à formação do geógrafo, em seus aspectos teórico, técnico e crítico, esta apreciação foi subsidiada por meio da análise do Plano de Metas Acadêmicas do Departamento de Geografia - período 2004-2008, visto que em outras publicações oficiais, os dados disponibilizados se referem, sobretudo, aos geógrafos que atuam na área de ensino, tal como verificado no Ministério da Educação (MEC) e nos Planos Curriculares Nacionais (PCNs), voltados para o ensino fundamental, ou médio.

A partir destas informações ficou evidente a colaboração do geógrafo nos estudos de impacto ambiental, demonstrando ser importante a presença deste, na equipe multidisciplinar reunida para a elaboração do EIA, seja na preparação de um ou mais relatórios internos do mesmo, seja na confecção dos mapas constantes no trabalho, bem como, na própria coordenação dos EIAs, dada à visão multidisciplinar e integradora de diversos campos teóricos e técnicos presentes na grade curricular do curso bacharelado de Geografia.

Um objetivo específico alcançado se deu a partir da revisão das atividades pertinentes aos geógrafos junto ao CREA - Conselho Regional de Engenharia e Arquitetura, no exercício de buscar para cada relatório, o item legal que ampara o geógrafo na elaboração dos mesmos. Num primeiro momento, acreditávamos que não havia amparo legal para o amplo espectro de atuação do geógrafo nos EIAs, mas após esta verificação, isto parece ter ficado resolvido. 
Cabe apenas uma ressalva, como dito anteriormente: as respostas para os geógrafos junto ao CREA são extremamente morosas, haja vista uma consulta de dúvida deste autor em agosto de 2008, que até março de 2010 ainda não foi respondida e provavelmente não o será definitivamente: na Região Metropolitana de São Paulo, já elaborei trabalhos e recolhi a ART deles, em laudos de caracterização de vegetação (sem o cadastramento arbóreo individual de cada exemplar, trabalho executável por biólogos, engenheiros agrônomos e florestais). Porém, ao tentar elaborar um destes relatórios para o estado de Mato Grosso do Sul, a Secretaria de Meio Ambiente/MS, não aceitou, dizendo só ser permitido para engenheiros agrônomos, florestais ou biólogos.

A análise da perda de (ou o pouco) espaço na atuação no licenciamento e nos estudos de impacto ambiental por parte dos geógrafos, em comparação com outros profissionais, de forma quantitativa e qualitativa, por meio de apresentação de textos e tabelas comparativas, foi realizada no próximo item desta dissertação.

Os novos e antigos caminhos de atuação para os geógrafos foram apontados, a partir da comparação realizada entre as atribuições legais e as atividades que concretamente têm sido realizadas pelos mesmos, na busca de tentar verificar: qual tem sido a real participação (quantitativa e qualitativa) destes nos EIAs, apreendendo sua dimensão, quando comparada com profissionais de outras áreas de formação.

O andamento e a conclusão desta pesquisa permitiram entender de maneira mais profunda, o porquê de os geógrafos terem capacidade de atuação nos estudos de impacto ambiental, compreendendo em quase todos os detalhes de onde emana sua competência para tal. A grade multidisciplinar, a formação teórica, técnica, crítica, a compreensão de análise dos meios físico e antrópico de forma mais profunda e do meio biótico de forma complementar, bem como a inter-relação entre eles, trazem a este cientista e profissional, uma gama de possibilidades de atuação imensa.

O geógrafo, já possui certo reconhecimento neste ramo de atividade profissional, conforme será visto no próximo item deste trabalho, de forma quantitativa e qualitativa. Ainda assim, dada a complexidade e dimensionamento de sua formação, 
ele poderia atuar de maneira mais intensa, uma vez, que ainda há muito que explorar neste campo.

São poucos os profissionais, que mesmo com pouco tempo de atuação, apresentam a capacidade de apreender o espaço de forma integrada num estudo de impacto ambiental, a vivência nesta área aponta, que muitos profissionais percebem a implantação de um novo empreendimento de forma fragmentada, absorvendo somente os impactos de seu campo de atuação, enquanto que os outros impactos são formulações repetidas de cópias de outros estudos.

\subsection{Conclusões Qualitativas e Quantitativas}

As conclusões qualitativas e quantitativas apresentadas a seguir, foram obtidas de duas maneiras distintas: a primeira refere-se à análise empreendida em 40 estudos de impacto ambiental protocolados, ou em fase de protocolização, junto a SMA/CETESB, referentes ao período 2000-2009, estando divididos da seguinte maneira: 01 PRAD, 01 EAS, 18 RAP's e 20 EIA-RIMA's; os dois primeiros de pequeno porte apresentam equipes técnicas reduzidas e por este motivo, foram analisados somente dois deste tipo de estudo de impacto ambiental; já os 18 RAP's (empreendimentos, grosso modo, considerados como de médio porte) e; 20 EIARIMAs, que representam equipes técnicas multidisciplinares maiores, possibilitando uma análise mais abrangente da participação dos geógrafos, neste ramo de atividade profissional.

A participação quantitativa dos geógrafos em estudos de impacto ambiental será exposta nas tabelas anexas 6.1-1 (estudos de pequeno e médio portes: PRAD, EAS e RAP's) e; 6.1-2 (estudos de grande porte: EIA-RIMA's), apresentadas a seguir e, na sequência, têm-se alguns dados relevantes em destaque, obtidos, a partir da verificação das mesmas. 


\begin{tabular}{|c|c|c|c|c|c|c|c|c|c|c|c|c|c|c|c|c|c|c|c|c|c|c|}
\hline $\begin{array}{c}\text { Estudo } \\
\text { Ambiental }\end{array}$ & $\begin{array}{l}\text { PRA } \\
\text { D } \\
\end{array}$ & EAS & RAP & RAP & RAP & RAP & RAP & RAP & RAP & RAP & RAP & RAP & RAP & RAP & RAP & RAP & RAP & RAP & RAP & RAP & \multirow{3}{*}{$\begin{array}{l}\text { Tota } \\
1 \text { de } \\
\text { Profi } \\
\text { s- } \\
\text { sion } \\
\text { ais }\end{array}$} & \multirow{3}{*}{ Posição } \\
\hline $\begin{array}{l}\text { Empreendi } \\
\text { mento }\end{array}$ & $\begin{array}{l}\text { Cerâ } \\
\text { mica }\end{array}$ & $\begin{array}{c}\text { Linh } \\
\text { a } \\
\text { Tran } \\
\text { smis } \\
\text { são }\end{array}$ & $\begin{array}{l}\text { Distr } \\
\text { ibuị̧ } \\
\text { âo } \\
\text { Gás }\end{array}$ & $\begin{array}{l}\text { Min } \\
\text { erą̧ } \\
\text { ão }\end{array}$ & $\begin{array}{l}\text { Pisci } \\
\text { não }\end{array}$ & $\begin{array}{l}\text { Parq } \\
\text { ue } \\
\text { Aqu } \\
\text { ático }\end{array}$ & $\begin{array}{l}\text { Usin } \\
\text { a } \\
\text { Alco } \\
\text { ol }\end{array}$ & $\begin{array}{l}\text { Lote } \\
\text { ame } \\
\text { nto }\end{array}$ & $\begin{array}{c}\text { Ater } \\
\text { ro } \\
\text { Sanit } \\
\text { ário }\end{array}$ & $\begin{array}{l}\text { Indú } \\
\text { stria }\end{array}$ & $\begin{array}{l}\text { Indú } \\
\text { stria }\end{array}$ & $\begin{array}{l}\text { Distr } \\
\text { ibuiç } \\
\text { ão } \\
\text { Gás }\end{array}$ & $\begin{array}{l}\text { Est. } \\
\text { Trat. } \\
\text { Esgo } \\
\text { to }\end{array}$ & $\begin{array}{c}\text { Peq. } \\
\text { Cent } \\
\text { ral } \\
\text { Hidr } \\
\text { elétri } \\
\text { ca }\end{array}$ & $\begin{array}{l}\text { Usin } \\
\text { a } \\
\text { Alco } \\
\text { ol }\end{array}$ & $\begin{array}{c}\text { Linh } \\
\text { a } \\
\text { Tran } \\
\text { smis } \\
\text { são }\end{array}$ & $\begin{array}{l}\text { Lote } \\
\text { ame } \\
\text { nto }\end{array}$ & $\begin{array}{l}\text { Loteame } \\
\text { nto }\end{array}$ & $\begin{array}{l}\text { Rod } \\
\text { ovia }\end{array}$ & $\begin{array}{l}\text { Rod } \\
\text { ovia }\end{array}$ & & \\
\hline Ano & 2005 & 2006 & 2001 & 2002 & 2002 & 2003 & 2005 & 2003 & 2005 & 2005 & 2006 & 2006 & 2006 & 2006 & 2007 & 2007 & 2007 & 2007 & 2008 & 2009 & & \\
\hline $\begin{array}{l}\text { Número de } \\
\text { Profissionai } \\
\text { s na Equipe } \\
\end{array}$ & 03 & 04 & 05 & 06 & 07 & 11 & 04 & 05 & 04 & 06 & 10 & 11 & 07 & 15 & 11 & 09 & 09 & 09 & 10 & 07 & 153 & \\
\hline \multicolumn{23}{|l|}{$\begin{array}{c}\text { Profissionai } \\
\mathrm{s}\end{array}$} \\
\hline Geógrafo & & 1 & & & & & & & & & & 2 & 1 & 2 & & 1 & & & 1 & 1 & 09 & $6^{\circ}$ \\
\hline $\begin{array}{c}\text { Administra } \\
\text { dor }\end{array}$ & & & & & & & & & & & & & & & & & & & 1 & & 01 & \\
\hline $\begin{array}{l}\text { Advogado } \\
\end{array}$ & & & & & & & & & & 1 & - & & & & & 1 & & & - & & 02 & \\
\hline Arqueólogo & & & & & & & & & & & & 3 & 1 & & 1 & & 1 & 1 & & & 07 & \\
\hline $\begin{array}{l}\text { Arquiteto } \\
\end{array}$ & & & & & 1 & 4 & & 1 & & & & 1 & & & & & & & & & 07 & \\
\hline $\begin{array}{l}\text { Biólogo } \\
\end{array}$ & & 1 & & & & 2 & & 2 & & 2 & 1 & & & 5 & 1 & 1 & 4 & 4 & 1 & 1 & 25 & $1^{\circ}$ \\
\hline $\begin{array}{c}\text { Desenhista / } \\
\text { Projetista } \\
\end{array}$ & & & & & & & 1 & & & & 1 & & & & & 2 & & & 1 & & 05 & \\
\hline $\begin{array}{l}\text { Ecólogo } \\
\end{array}$ & & & 2 & & & & & & & & & 1 & & & & & & & & & 03 & \\
\hline 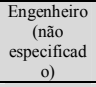 & & & 2 & & & & & 1 & & & & & 1 & & & & & & & & 04 & \\
\hline $\begin{array}{c}\text { Eng. } \\
\text { Agrícola } \\
\end{array}$ & & & & & & & & & & & & & & & 1 & & & & & & 01 & \\
\hline $\begin{array}{c}\text { Eng. } \\
\text { Agrimensor }\end{array}$ & & & & & & 1 & & & & & & & & & & & & & & & 01 & \\
\hline $\begin{array}{c}\text { Eng. } \\
\text { Agrônomo }\end{array}$ & 1 & & & & & 1 & 1 & & 1 & & 1 & 1 & & 2 & 1 & & & & 2 & & 11 & $5^{\circ}$ \\
\hline $\begin{array}{c}\text { Eng. } \\
\text { Ambiental }\end{array}$ & & & & & & & & & & & 2 & & & & 1 & & & & 1 & & 04 & \\
\hline Eng. Civil & & 1 & & 2 & 1 & & 1 & & & 1 & 1 & 2 & 4 & 1 & 1 & 2 & 1 & 1 & & 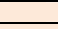 & 19 & $3^{\circ}$ \\
\hline $\begin{array}{c}\text { Eng. } \\
\text { Florestal }\end{array}$ & & & & 2 & 4 & 1 & & & & & & & & & 1 & 1 & & & 1 & 2 & 12 & $4^{\circ}$ \\
\hline $\begin{array}{c}\text { Eng. } \\
\text { Mecânico } \\
\end{array}$ & & & & & & & & & & & & & & & 1 & & & 1 & & & 02 & \\
\hline Eng. Minas & & & & & & & & & & - & 1 & & & & 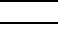 & & & & 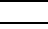 & 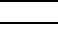 & 01 & \\
\hline $\begin{array}{c}\text { Eng. } \\
\text { Produção }\end{array}$ & & & & & & & & & & 1 & & & & & & & & & & & 01 & \\
\hline $\begin{array}{c}\text { Eng. } \\
\text { Químico } \\
\end{array}$ & & & & & & & & & 1 & & 2 & & & & 1 & & & & & & 04 & \\
\hline $\begin{array}{c}\text { Eng. } \\
\text { Sanitarista }\end{array}$ & 1 & & & & & & & & & & & & & & & & & & & & 01 & \\
\hline $\begin{array}{l}\text { Geólogo } \\
\end{array}$ & 1 & 1 & 1 & 1 & 1 & 1 & & 1 & 2 & 1 & 1 & 1 & & 2 & 1 & 1 & 2 & 1 & 1 & 1 & 21 & $2^{\circ}$ \\
\hline $\begin{array}{c}\text { Oceanógraf } \\
\text { o }\end{array}$ & & & & & & 1 & & & & & & & & & & & & & & & 01 & \\
\hline $\begin{array}{l}\text { Sociólogo } \\
\end{array}$ & & & & 1 & & & & & & & & & & & 1 & & 1 & 1 & 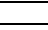 & 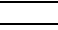 & 04 & \\
\hline $\begin{array}{l}\text { Técnico } \\
\text { Seg. } \\
\text { Trabalho }\end{array}$ & & & & & & & & & & & & & & & & & & & & 1 & 01 & \\
\hline $\begin{array}{l}\text { Tecnólogo } \\
\text { Ambiental }\end{array}$ & & & & & & & 1 & & & & & & & 3 & & & & & 1 & 1 & 06 & \\
\hline
\end{tabular}




\begin{tabular}{|c|c|c|c|c|c|c|c|c|c|c|c|c|c|c|c|c|c|c|c|c|c|c|}
\hline $\begin{array}{l}\text { Estudo } \\
\text { Ambiental }\end{array}$ & $\begin{array}{l}\text { EIA- } \\
\text { RIM } \\
\text { A }\end{array}$ & $\begin{array}{c}\text { EIA- } \\
\text { RIM } \\
\text { A }\end{array}$ & $\begin{array}{l}\text { EIA- } \\
\text { RIM } \\
\text { A }\end{array}$ & $\begin{array}{l}\text { EIA- } \\
\text { RIM } \\
\text { A }\end{array}$ & $\begin{array}{c}\text { EIA- } \\
\text { RIM } \\
\text { A }\end{array}$ & $\begin{array}{l}\text { EIA- } \\
\text { RIM } \\
\text { A }\end{array}$ & $\begin{array}{l}\text { EIA- } \\
\text { RIM } \\
\text { A }\end{array}$ & $\begin{array}{l}\text { EIA- } \\
\text { RIM } \\
\text { A }\end{array}$ & $\begin{array}{c}\text { EIA- } \\
\text { RIM } \\
\text { A }\end{array}$ & $\begin{array}{c}\text { EIA- } \\
\text { RIM } \\
\text { A }\end{array}$ & $\begin{array}{c}\text { EIA- } \\
\text { RIM } \\
\text { A } \\
\end{array}$ & $\begin{array}{c}\text { EIA- } \\
\text { RIM } \\
\text { A }\end{array}$ & $\begin{array}{c}\text { EIA- } \\
\text { RIM } \\
\text { A } \\
\end{array}$ & $\begin{array}{c}\text { EIA- } \\
\text { RIM } \\
\text { A }\end{array}$ & $\begin{array}{c}\text { EIA- } \\
\text { RIM } \\
\text { A }\end{array}$ & $\begin{array}{c}\text { EIA- } \\
\text { RIM } \\
\text { A }\end{array}$ & $\begin{array}{c}\text { EIA- } \\
\text { RIM } \\
\text { A }\end{array}$ & $\begin{array}{c}\text { EIA- } \\
\text { RIM } \\
\text { A } \\
\end{array}$ & $\begin{array}{c}\text { EIA- } \\
\text { RIM } \\
\text { A }\end{array}$ & $\begin{array}{c}\text { EIA- } \\
\text { RIM } \\
\mathrm{A}\end{array}$ & \multirow{3}{*}{$\begin{array}{l}\text { Tota } \\
1 \text { de } \\
\text { Profi } \\
\text { s- } \\
\text { sion } \\
\text { ais }\end{array}$} & \multirow{3}{*}{$\begin{array}{c}\text { Posiç } \\
0\end{array}$} \\
\hline $\begin{array}{c}\text { Empreendi } \\
\text { mento }\end{array}$ & $\begin{array}{c}\text { Aero } \\
\text { port } \\
0\end{array}$ & $\begin{array}{c}\text { Ater } \\
\text { ro } \\
\text { Sanit } \\
\text { ário }\end{array}$ & $\begin{array}{l}\text { Aterr } \\
\text { o } \\
\text { Sanit } \\
\text { ário }\end{array}$ & $\begin{array}{l}\text { Lote } \\
\text { ame } \\
\text { nto }\end{array}$ & $\begin{array}{l}\text { Lote } \\
\text { ame } \\
\text { nto }\end{array}$ & $\begin{array}{l}\text { Indú } \\
\text { stria }\end{array}$ & $\begin{array}{l}\text { Lote } \\
\text { ame } \\
\text { nto }\end{array}$ & $\begin{array}{c}\text { Usin } \\
\text { a }\end{array}$ & $\begin{array}{c}\text { Port } \\
0\end{array}$ & $\begin{array}{c}\text { Aero } \\
\text { port } \\
\text { o }\end{array}$ & $\begin{array}{l}\text { Usin } \\
\mathrm{a}\end{array}$ & $\begin{array}{l}\text { Indú } \\
\text { stria }\end{array}$ & $\begin{array}{c}\text { Expr } \\
\text { esso } \\
\text { Aero } \\
\text { port } \\
\text { o } \\
\end{array}$ & $\begin{array}{c}\text { Aero } \\
\text { port } \\
0\end{array}$ & $\begin{array}{l}\text { Rod } \\
\text { ovia }\end{array}$ & $\begin{array}{l}\text { Rod } \\
\text { ovia }\end{array}$ & $\begin{array}{l}\text { Poli } \\
\text { duto }\end{array}$ & $\begin{array}{l}\text { Aterr } \\
\text { o } \\
\text { Sanit } \\
\text { ário }\end{array}$ & $\begin{array}{c}\text { Rod } \\
\text { oane } \\
1 \\
\text { Lest } \\
\text { e } \\
\end{array}$ & $\begin{array}{l}\text { Lote } \\
\text { ame } \\
\text { nto }\end{array}$ & & \\
\hline Ano & 2000 & 2002 & 2002 & 2003 & 2005 & 2006 & 2007 & 2007 & 2007 & 2008 & 2008 & 2008 & 2008 & 2008 & 2009 & 2009 & 2009 & 2009 & 2009 & 2009 & & \\
\hline $\begin{array}{c}\text { Número de } \\
\text { Profissiona } \\
\text { is na } \\
\text { Equipe } \\
\end{array}$ & 20 & 10 & 14 & 18 & 20 & 13 & 09 & 10 & 11 & 20 & 17 & 28 & 13 & 24 & 18 & 19 & 25 & 14 & 41 & 16 & 360 & \\
\hline \multicolumn{23}{|l|}{$\begin{array}{l}\text { Profissiona } \\
\text { is }\end{array}$} \\
\hline Geógrafo & 3 & & 2 & 2 & & 1 & & & & 3 & 2 & 2 & & 3 & 3 & 3 & 1 & & 3 & 2 & 30 & $4^{\circ}$ \\
\hline $\begin{array}{c}\text { Administra } \\
\text { dor }\end{array}$ & & & & & & & & & & & & & 1 & 1 & & & & & & & 02 & \\
\hline Advogado & 1 & & & 1 & 2 & & & & 1 & 1 & & 1 & 1 & 2 & 1 & 1 & 6 & & & & 18 & $6^{\circ}$ \\
\hline Arquiteto & 1 & & 2 & 1 & 3 & & & & 2 & 1 & 1 & & & 3 & 2 & 2 & & & 6 & 1 & 25 & $5^{\circ}$ \\
\hline Biólogo & 5 & 3 & 1 & 3 & 3 & 5 & 4 & 1 & 1 & 5 & 5 & 5 & 2 & 2 & 2 & 2 & 1 & 3 & 17 & 4 & 74 & $1^{\circ}$ \\
\hline $\begin{array}{l}\text { Desenhista } \\
\text { / Projetista } \\
\end{array}$ & & & 1 & & & 2 & & & 3 & & & 1 & & 1 & & & & & 1 & 1 & 10 & \\
\hline Ecólogo & & & & & & & & & & & & & & & & & 1 & & & & 01 & \\
\hline $\begin{array}{c}\text { Economist } \\
a\end{array}$ & 1 & & & & 1 & & & & & 1 & 1 & & & 2 & & & & & & & 06 & \\
\hline $\begin{array}{c}\text { Engenheir } \\
\text { o (não } \\
\text { especificad } \\
\text { o) } \\
\end{array}$ & & 1 & 1 & & 1 & & & & & & & & & 1 & 4 & 4 & & & & & 12 & $8^{\circ}$ \\
\hline $\begin{array}{c}\text { Eng. } \\
\text { Agricola } \\
\end{array}$ & & & & & & & & 1 & & & & & & & & & & & & & 01 & \\
\hline $\begin{array}{c}\text { Eng. } \\
\text { Agrimenso } \\
\mathrm{r}\end{array}$ & & & & & 1 & & & & & & & & & & & & & & & & 01 & \\
\hline $\begin{array}{c}\text { Eng. } \\
\text { Agrônomo }\end{array}$ & 1 & & & 1 & 3 & & 1 & 1 & 1 & 1 & 1 & & 2 & 1 & & & 2 & & 1 & & 16 & $7^{\circ}$ \\
\hline $\begin{array}{c}\text { Eng. } \\
\text { Cartógrafo }\end{array}$ & & & & & & & & & 1 & & & & & & & & & & & & 01 & \\
\hline Eng. Civil & & 1 & 3 & 8 & 1 & 1 & 1 & 1 & 1 & & 2 & 4 & & 2 & & & & 2 & 5 & 3 & 35 & $3^{\circ}$ \\
\hline $\begin{array}{c}\text { Eng. } \\
\text { Florestal }\end{array}$ & & & & & & & & 1 & & & & & 2 & & & & 6 & & 1 & 1 & 11 & \\
\hline $\begin{array}{c}\text { Eng. } \\
\text { Mecânico }\end{array}$ & 1 & & & & 1 & & & 1 & & 1 & 1 & & & & 1 & 1 & & 1 & 1 & & 09 & \\
\hline $\begin{array}{c}\text { Eng. } \\
\text { Produção }\end{array}$ & 1 & & & & & & & & & 1 & & & & & & & & & & & 02 & \\
\hline $\begin{array}{c}\text { Eng. } \\
\text { Químico }\end{array}$ & 1 & & 1 & & & & & 1 & & 1 & & 1 & & 2 & & & & & 1 & 1 & 09 & \\
\hline Geofisico & & & & & & & & & & & & & & & & & & 2 & & & 02 & \\
\hline Geólogo & 3 & 2 & 1 & 1 & 2 & 4 & 1 & 1 & & 3 & 1 & 3 & 2 & 1 & 3 & 3 & 4 & 2 & 2 & 2 & 41 & $2^{\circ}$ \\
\hline Físico & & 1 & 1 & & & & & & & & & & & & & & & 1 & & & 03 & \\
\hline Jornalista & & & & & & & & & & & & & & & 1 & 1 & & & & & 02 & \\
\hline $\begin{array}{c}\text { Oceanógra } \\
\text { fo }\end{array}$ & & & & & & & & & 1 & & & & & & & & & & & & 01 & \\
\hline Sociólogo & & 1 & & & & & 1 & & & & & 1 & & 2 & 1 & 2 & & 1 & 1 & 1 & 11 & $9^{\circ}$ \\
\hline $\begin{array}{c}\text { Téenico } \\
\text { Seg. } \\
\text { Trabalho } \\
\end{array}$ & & & & & & & & & & & & 1 & & & & & 1 & & & & 02 & \\
\hline $\begin{array}{l}\text { Tecnólogo } \\
\text { Ambiental }\end{array}$ & & 1 & 1 & & & & & & & & 2 & 4 & 1 & & & & 2 & 1 & & & 12 & $8^{\circ}$ \\
\hline
\end{tabular}


Nos estudos de impacto ambiental de pequeno e médio portes (PRAD, EAS e RAP's), num total de 153 profissionais envolvidos na elaboração dos 20 estudos, havia 09 geógrafos, o que representa $5,9 \%$ do total de pessoas; já a participação em total de estudos se deu em 07 dos 20 EIAs, representando $35 \%$ ou, 1/3 dos estudos contou com geógrafos em sua equipe multidisciplinar, podendo-se ser considerada uma boa representatividade.

Contudo, ao se analisar a participação de outros profissionais nestes mesmos estudos, tem-se que os geógrafos (09), estariam atrás de 11 engenheiros agrônomos, 12 engenheiros florestais, 19 engenheiros civis, 21 geólogos e 25 biólogos, situando-se, portanto, na $6^{a}$ colocação.

Pode-se afirmar, a partir dos números acima que, de certa forma até surpreende a $6^{a}$ colocação para os geógrafos, visto que se pensava, inicialmente, haver uma participação menor, deste profissional; os outros profissionais, com maior representatividade são também bastante importantes para a formação da equipe técnica multidisciplinar. A única observação neste caso, se faz ao número de engenheiros civis (19), ocupando a $3^{a}$ posição, com o maior número de profissionais, levando-se em consideração, que se trata somente da análise das equipes técnicas da elaboração dos EIAs e não dos projetos construtivos, por exemplo; assim, este número parece um pouco exagerado, para estudos ambientais.

Já em relação aos estudos, aqui, grosso modo, definidos, para empreendimentos maiores, os EIA-RIMAs, num total de 20 analisados, com a participação total de 360 profissionais, havia 30 geógrafos, ou $8,3 \%$ dos participantes e com presença em 13 dos 20 EIAs, portanto em $65 \%$ do total.

$\mathrm{Na}$ comparação com outros profissionais participantes da equipe técnica de elaboração dos EIA-RIMAs, dos 360 técnicos, tem-se que: em primeiro lugar, aparecem os biólogos com 74 deste total; seguidos pelos geólogos, com 41, em segundo lugar; engenheiros civis, com 35, em terceiro; geógrafos, 30 destes, na quarta colocação; arquitetos, 25, em quinto; 18 advogados, em sexto; 16 engenheiros agrônomos, na sétima posição; e em oitavo, 12 arqueólogos, 12 engenheiros (com área não especificada) e 12 tecnólogos ambientais. 
A tabela resumo 6.1-3 a seguir, apresenta os doze profissionais que mais atuaram nos 40 ElAs analisados, assim como, em quantos destes havia os profissionais mencionados.

\begin{tabular}{|c|c|c|c|c|c|}
\hline \multicolumn{6}{|c|}{ TABELA RESUMO } \\
\hline \multirow{2}{*}{ Formação } & $\begin{array}{c}\text { Número de } \\
\text { Profissionais } \\
\text { nos } 40 \text { EIAs } \\
\text { Analisados: } \\
\mathbf{5 1 3}\end{array}$ & \multirow{2}{*}{$\begin{array}{c}\text { Posição em } \\
\text { Relação ao } \\
\text { Total de } \\
\text { Profissionais }\end{array}$} & $\begin{array}{l}\text { Número de } \\
\text { Estudos de } \\
\text { Impacto } \\
\text { Ambiental } \\
\text { (EAS, PRAD, } \\
\text { RAP, EIA- } \\
\text { RIMA): } 40 \\
\end{array}$ & \multirow{2}{*}{$\begin{array}{l}\text { Participação } \\
\text { dos } \\
\text { Profissionais } \\
\text { no Total dos } \\
\text { EIAs em } \\
\text { porcentagem } \\
\text { em relação ao } \\
\text { total }\end{array}$} & \multirow{2}{*}{$\begin{array}{l}\text { Posição dos } \\
\text { Profissionais } \\
\text { em relação a } \\
\text { participação } \\
\text { no Total dos } \\
\text { EIAs }\end{array}$} \\
\hline & $\begin{array}{l}\text { Número de } \\
\text { Profissionais } \\
\text { na Equipe }\end{array}$ & & $\begin{array}{c}\text { Participação } \\
\text { dos } \\
\text { Profissionais } \\
\text { em relação ao } \\
\text { Total dos } \\
\text { EIAs } \\
\end{array}$ & & \\
\hline Geógrafo & 39 & $4^{\circ}$ & 20 & $50,0 \%$ & $5^{\circ}$ \\
\hline Advogado & 20 & $8^{\circ}$ & 13 & $32,5 \%$ & $8^{\circ}$ \\
\hline Arqueólogo & 19 & $09^{\circ}$ & 15 & $37,5 \%$ & $7^{\circ}$ \\
\hline Arquiteto & 32 & $5^{\circ}$ & 16 & $40,0 \%$ & $6^{\circ}$ \\
\hline Biólogo & 99 & $1^{\circ}$ & 32 & $80,0 \%$ & $2^{\circ}$ \\
\hline $\begin{array}{c}\text { Eng.(não } \\
\text { especificado) }\end{array}$ & 16 & $11^{\circ}$ & 09 & $22,5 \%$ & $11^{\circ}$ \\
\hline Eng. Agrônomo & 27 & $6^{\circ}$ & 21 & $52,5 \%$ & $4^{\circ}$ \\
\hline Eng. Civil & 54 & $3^{\circ}$ & 27 & $67,5 \%$ & $3^{\circ}$ \\
\hline Eng. Florestal & 23 & $7^{\circ}$ & 12 & $30,0 \%$ & $9^{\circ}$ \\
\hline Geólogo & 62 & $2^{\circ}$ & 37 & $92,5 \%$ & $1^{\circ}$ \\
\hline $\begin{array}{l}\text { Tecnólogo } \\
\text { Ambiental }\end{array}$ & 18 & $10^{\circ}$ & 11 & $27,5 \%$ & $10^{\circ}$ \\
\hline
\end{tabular}

Tabela 6.1-3: Resumo do Número de profissionais que mais participaram dos EIAs.

A tabela resumo apresentada, evidencia alguns fatos importantes, primeiro que no cômputo geral dos 40 EIAs analisados, em $50 \%$ deles havia geógrafos nas equipes técnicas multidisciplinares, este número poderia ser maior, se considerado o potencial de atuação deste profissional, a partir dos atributos mencionados anteriormente neste trabalho, sob os aspectos teóricos, técnicos e crítico, bem como na capacidade de elaboração de tão variados relatórios possibilitadas por esta 
formação, além da contribuição na execução dos mapas e coordenação dos estudos, contudo, deve-se considerar que os geógrafos encontram-se no $4^{\circ}$ lugar em relação aos profissionais que mais participaram na elaboração dos mesmos, estando atrás somente de biólogos, geólogos e engenheiros civis, em relação ao número total de profissionais e em $5^{\circ}$ lugar, na participação em relação à presença do profissional na equipe técnica.

Não há o que contestar sobre a grande presença de geólogos e biólogos nas equipes técnicas, visto que em determinados relatórios, a presença destes profissionais é fundamental, no meio físico para os geólogos (geologia e hidrogeologia, por exemplo) e no meio biótico para os biólogos (vegetação, fauna: mastofauna, ictiofauna, herpetofauna etc.) e esses resultados já eram esperados.

O que causa certo estranhamento é o número de engenheiros civis, ocupando o terceiro lugar, tanto em número de profissionais, como em sua presença na maioria do EIAs verificados, não que este profissional não deva contribuir, mas mereceria um estudo mais aprofundado o porquê de tal representatividade (a qual não deve ser explicada somente pelo maior número de profissionais formados em relação a outros que atuam nesta área). Questionamento semelhante pode ser feito sobre a presença dos arquitetos nestes estudos, aparecendo em maior número, que engenheiros agrônomos e florestais.

É muito complicado julgar a importância ou não, de determinados profissionais numa equipe técnica multidisciplinar, visto que em alguns empreendimentos, certos profissionais são mais importantes do que outros. Bem como, alguns aspectos acabam não sendo apreendidos nesta abordagem quantitativa, como por exemplo, em algumas equipes técnicas de determinadas consultorias, alguns dos profissionais que ali constam não participaram efetivamente do trabalho e constam na mesma, por fazerem, às vezes, parte de seu quadro de funcionários; ou então, consta um profissional como responsável por determinado meio (físico, biótico, ou antrópico) e na verdade quem elabora alguns dos estudos constantes em um destes meios não aparece na equipe técnica; ou ainda, como é muito comum, sobretudo, para o meio antrópico, muitas vezes, pouco valorizado por determinadas consultorias ambientais, de relegarem aos profissionais de nível médio, ou formações diversas, e estes não 
constarem, igualmente no quadro das equipes técnicas e; até questões políticoburocráticas, de um profissional elaborar um determinado relatório e outro constar como executor.

Ainda assim, acreditamos que as tabelas apresentadas e o exame das mesmas representam um retrato bastante próximo da realidade existente nas consultorias ambientais e na participação dos profissionais que elaboram os estudos a serem protocolados nos órgãos competentes, para a análise e emissão de licenças.

Já em relação aos profissionais que analisam os estudos de impacto ambiental, será apresentado agora, o quadro de técnicos que em janeiro de 2009, na época deste levantamento, eram incumbidos desta tarefa, para a maior parte dos EIAs protocoladas na Secretaria Estadual de Meio Ambiente do Estado de São Paulo.

\begin{tabular}{|l|c|c|}
\hline \multicolumn{3}{|c|}{ Equipe Técnica - DAIA* - Janeiro/2009 } \\
\hline Profissionais & Número & Posição \\
\hline Geógrafo & $\mathbf{1 2}$ & $\mathbf{1}^{\circ}$ \\
\hline Psicólogo & 01 & $8^{\circ}$ \\
\hline Eng. Sanitarista & 02 & $7^{\circ}$ \\
\hline Eng. Civil & 02 & $7^{\circ}$ \\
\hline Eng. Ambiental & 07 & $3^{\circ}$ \\
\hline Eng. Agrônomo & 02 & $7^{\circ}$ \\
\hline Advogado & 03 & $6^{\circ}$ \\
\hline Economista & 01 & $8^{\circ}$ \\
\hline Biólogo & 08 & $2^{\circ}$ \\
\hline Arquiteto & 04 & $5^{\circ}$ \\
\hline Geólogo & 05 & $4^{\circ}$ \\
\hline Biomédico & 01 & $8^{\circ}$ \\
\hline Tecnólogo Ambiental & 03 & $6^{\circ}$ \\
\hline Sociólogo & 01 & $8^{\circ}$ \\
\hline Ecólogo & 01 & $8^{\circ}$ \\
\hline Total & 52 & \\
\hline
\end{tabular}


* DAIA: Departamento de Avaliação de Impacto Ambiental foi incorporado pela CETESB e a Diretoria de Tecnologia, Qualidade e Avaliação Ambiental é a nova responsável pela análise da maioria dos estudos de impacto ambiental.

Tabela 6.1-4: Quadro de Técnicos do DAIA, em Janeiro de 2009, época do levantamento das informações.

O quadro de técnicos do DAIA, quando comparado ao de profissionais que elaboram os EIAs, apresenta algumas diferenças consideráveis, a mais evidente se dá no número de geógrafos existentes neste departamento (atual diretoria de Tecnologia, Qualidade e Avaliação Ambiental) com 12 pessoas, se destacando em primeiro lugar, seguido de 08 biólogos, 07 engenheiros ambientais, 05 geólogos e 04 arquitetos; já engenheiros civis, que ocupam o terceiro lugar em elaboração de EIAs, no levantamento realizado, aparecem na sétima posição, com 02 profissionais no DAIA.

O que pode se concluir deste quadro de funcionários é que, os profissionais com formações multidisciplinares: geógrafos, engenheiros ambientais e biólogos são mais representados em quantidade, possivelmente, por poderem analisar mais capítulos dos EIAs, quando comparados com profissionais mais específicos, deduzindo-se haver uma maior valorização no órgão analisador deste perfil profissional, embora possa haver também, outros motivos por trás destes números, que não teriam cunho científico, mas somente especulativo.

Chama também a atenção, o número de engenheiros civis, apenas dois, ocupando a sétima colocação, em detrimento de diversos outros profissionais, demonstrando haver muito mais destes técnicos na elaboração, do que na análise dos EIAs.

Sob o ponto de vista qualitativo pretendia-se, inicialmente, demonstrar quais os capítulos contidos nos EIAs têm sido elaborados pelos geógrafos e quais poderiam ser feito por este profissional e são realizados por outros técnicos, a partir do levantamento destes 40 EIAs já mencionados, contudo, esta tarefa ficou comprometida por não haverem na maioria dos EIAs descritos, quais profissionais elaboraram determinados capítulos; muitas vezes havia somente o nome da pessoa e sua formação; em outras, acrescido de responsável pelo meio físico, ou biótico, ou 
antrópico, sem mencionar, em qual dos relatórios específicos. Portanto os dados a seguir serão generalizados por meios: físico, biótico e antrópico, além de coordenação dos EIAs e elaboração cartográfica.

Assim, a análise dos 40 EIAs e dentro destes, os que dispunham de informações, permitiu diagnosticar que: a coordenação, em sua maioria se deu por engenheiros civis (09 do total), geólogos (08), sociólogos (03), engenheiro florestal (01), 02 arquitetos, 02 engenheiros químicos, 01 engenheiro agrônomo, 01 biólogo e 01 geógrafo. Conforme já mencionado anteriormente, a experiência profissional é fundamental para se coordenar um estudo de impacto ambiental, por vezes, sendo tão ou mais importante do que a formação desta pessoa, contudo, causa certa estranheza a predominância de engenheiros civis, como os profissionais que mais marcaram presença nesta análise empreendida, mais até do que geólogos, biólogos, engenheiros agrônomos, florestais e geógrafos, este com apenas uma coordenação, nos 40 trabalhos analisados.

Para a elaboração de relatórios do meio físico, os números se apresentam da seguinte maneira: os geólogos participaram com 18 profissionais, seguidos por 08 engenheiros civis, 07 engenheiros mecânicos (este responsável por estudos de qualidade do ar), 05 geógrafos, 04 engenheiros ambientais (sem mencionar em quais capítulos) e mais 03 em estudos do clima e mais um geógrafo elaborando laudo geomorfológico e pedológico. Os números do meio físico, não apresentam nenhuma disparidade, aparentando certa normalidade na escala de número em relação aos profissionais envolvidos na elaboração. Uma análise qualitativa dos estudos, numa perspectiva futura, poderia, possivelmente, trazer novas respostas sobre sua elaboração, por estes profissionais.

Para o meio biótico, nos 40 EIAs analisados, em nenhum deles havia geógrafos na equipe técnica, algo também dentro da normalidade, embora acreditemos haver uma contribuição geográfica a ser dada, nos aspectos relacionados à vegetação.

Já no que se refere ao meio antrópico, a analise dos $40 \mathrm{EIAs}$, dentro daqueles em que havia disponibilidade de dados, verificou-se que, no computo geral, houve predominância de arquitetos na elaboração destes estudos, com 12 profissionais; seguido por 10 geógrafos, 06 sociólogos, 06 tecnólogos ambientais, 04 engenheiros 
civis, 02 economistas, 02 administradores de empresas, 02 advogados, 01 engenheiro agrônomo, 01 comunicador social. Estes números, como já eram esperados, apresentam uma dificuldade de entendimento, pois acreditamos, que determinadas formações não capacitam pessoas a atuarem em estudos de impacto ambiental do meio antrópico, tais como engenheiros civis (com exceção para estudo do sistema viário), administradores, comunicador social e engenheiro agrônomo, dentre outros profissionais, que constantemente elaboram estes relatórios, haja vista a convivência com inúmeros profissionais desta área de atuação e a pesquisa em muitos EIAs analisados, além de troca de informações com colegas sobre este assunto.

No que se refere à elaboração dos mapas contidos nos ElAs estudados, em 06 deles houve a participação de geógrafos, seguidos por 03 técnicos em informática, 01 técnico agrimensor, 01 técnico ambiental e 01 arquiteto, números estes dentro de certa normalidade, visto se tratar de um trabalho bastante disputado neste ramo de atividade, embora acreditemos, ter no geógrafo, um dos grandes profissionais capacitados a realizá-lo, dada a sua capacidade de espacializar os fenômenos.

Em relação aos questionários anexos $\mathrm{A}$ e $\mathrm{B}$, estes tinham o objetivo de testar $\mathrm{O}$ conhecimento acerca de outros profissionais em relação ao geógrafo; além de saber dos próprios geógrafos que trabalham neste ramo de atividade profissional, como eles se vêem neste campo de atividade.

Apesar de terem sido distribuídos 40 questionários por mim e por colegas, somente 14 pessoas o devolveram respondidos, mas de qualquer forma, as respostas foram suficientes para se atingir o propósito almejado, com pouca variação em seus conteúdos.

Assim, os 09 profissionais com outras formações, que responderam ao questionário acreditam na capacidade do geógrafo para a elaboração de relatórios constantes nos EIAs e quase por unanimidade, citam esta competência referindo-se aos meios físico e antrópico e até houve citação do meio biótico. Essas respostas também demonstraram que as pessoas deste ramo, conhecem a aptidão multidisciplinar obtida na formação do geógrafo, bem como sua capacidade de coordenação dos trabalhos, evidentemente que se referem sempre a experiências pessoais e de 
convivências em equipes multidisciplinares, às vezes com mais afinidade, às vezes com menos, em relação aos geógrafos.

As respostas demonstraram também, que a maioria dos profissionais acredita ter trabalhado com geógrafos, um indício de que a participação deste profissional é maior do que a pensada anteriormente a esta pesquisa, com participação variando de $30 \%$ do total de EIAs a até $100 \%$ dos casos, com uma média superior a $50 \%$ de participação.

Somente como observação: os relatos, no geral, são de que a qualidade do trabalho do geógrafo é considerada boa, a maioria das respostas aponta para isto, inclusive achando importante a presença deste profissional na equipe multidisciplinar.

Já, o questionário para os geógrafos, foi respondido por 05 pessoas, todas já atuantes neste ramo profissional; as respostas também se assemelharam bastante, todos se acham capacitados para atuar nos estudos de impacto ambiental, com pequenas ressalvas, acreditando estar aptos a atuarem em relatórios do meio físico e antrópico.

Como regra geral, esses 05 geógrafos que já atuaram em EIAs, acreditam que em cerca de $50 \%$ dos mesmos há este profissional nas equipes técnicas multidisciplinares e consideram imprescindível haver pelo menos 01 nas mesmas.

Como unanimidade, os geógrafos que responderam ao questionário se sentem desamparados pelo CREA, o qual eles julgaram não representar esta categoria profissional, tal com deveria.

A partir dos assuntos abordados anteriormente neste trabalho, e com a visão de quem já analisou capítulos dos EIA/RIMAs para o licenciamento no período de 02 anos de trabalho na SMA, sabendo da necessidade de fazê-lo de forma a não prejudicar o empreendedor, nem o meio ambiente, somada a pressão exercida por parte de uma hierarquia que muitas vezes exige uma aprovação rápida e emissão de documentos específicos de acordo com o empreendimento, por um lado. $E$ por outro, com o foco de quem por mais de quatro anos, participa da equipe de consultores, os quais elaboram os EIA/RIMAs, RAPs, EASs etc. e sabem da necessidade de aprovação do empreendimento por parte dos 
proprietários/investidores. Soma-se a isto, o fato da busca de adequar o empreendimento à mitigação do impacto no local e em seu entorno (na paisagem e na região), buscando-se muitas vezes, ganhos ambientais e sociais para a comunidade abrangida pela área de influência do empreendimento, além da necessidade de atender a todos os quesitos exigidos pelos órgãos ambientais envolvidos na análise. Para isso, o olhar do geógrafo, seja na elaboração de capítulos específicos contidos nos EIAs, confecção dos mapas, seja na coordenação do mesmo, com uma visão multidisciplinar, integradora, pode e deve contribuir para o enriquecimento de tais estudos.

Este trabalho não pretende ser corporativista, mas demonstrar caminhos novos e antigos a serem trilhados pelos bacharéis de Geografia, que queiram seguir sua carreira profissional, participando da elaboração e coordenação de Estudos de Impacto Ambiental e assim demonstrar os pontos fortes de atuação em que este profissional pode atuar de forma satisfatória.

O Geógrafo, por excelência, é um profissional multidisciplinar e pode, com mais facilidade do que outros técnicos elaborar e analisar muitas partes de um EIA/RIMA. Para auxiliá-lo nesta tarefa poderia ser criada no Departamento de Geografia das Universidades e até mesmo na Universidade de São Paulo, alguma disciplina que trouxesse maiores subsídios para isto, melhorando ainda mais a sua formação. Com isso, a Geografia da USP, não estaria se "rendendo ao mercado", mas apenas ajudando os profissionais dessa área a poder atuar com mais propriedade, uma vez que diversos cursos pelo país têm preparado os profissionais para atuarem neste ramo profissional, como exemplos, há os novos cursos de engenharia ambiental e gestão ambiental, com profissionais já em destaque nas abordagens quantitativas apresentadas anteriormente.

Algumas disciplinas já contribuem para isso, a Geomorfologia, Cartografia, Biogeografia, Pedologia e Climatologia, por exemplo, contudo poderia se criar uma matéria optativa que sistematizasse tais conhecimentos, aproximando ainda mais os geógrafos de uma possibilidade de atuação tão eminente.

O próprio Plano de Metas Acadêmicas do Departamento de Geografia, período 2004-2008 expõe que: 
"A formação acadêmica do geógrafo deve prepará-lo teórica e praticamente para atender às necessidades do mercado de trabalho, exigente e competitivo, afim de que não se excluam estes profissionais dos projetos multidisciplinares, por falta de condições operacionais e preparo tecnológico. Neste sentido, também, deve caminhar a formação abrangente e atualizada do profissional geógrafo." (DG, 2003, p. 11)

No mesmo documento lê-se que é necessário:

"Abrir e valorizar novas áreas de atuação de D.G. (sic) em especial as relacionadas a problemática ambiental e as mudanças geopolíticas do mundo hoje." (DG, 2003, p. 33)

Assim, esperamos que este trabalho tenha demonstrado a importância de se ter geógrafos atuando em estudos de impacto ambiental, se não esgotando as abordagens possíveis, ao menos deixando alguma contribuição. Como Kant já havia assinalado em sua Cosmologia "a criação jamais termina, jamais se completa. Uma vez iniciada, não pára. (apud Santos, 2002, p. 130) 


\section{FONTES E BIBLIOGRAFIA}

AB'SABER, A. N. Os Domínios de Natureza no Brasil. Potencialidades Paisagísticas. Ateliê Editorial, São Paulo, 2003.

AB'SABER, A. N.; PLATEBERG, C.M. (orgs.). Previsão de Impactos. Editora da Universidade de São Paulo, São Paulo, 1998.

BARBOSA, Rodolpho P. O método cartográfico. Curso de Geografia para professores do Ensino Superior. Rio de Janeiro, IBGE, 1968. p. 169-176.

BASTOS, Ana Christina Saramago; FREITAS, Antonio Carlos. Agentes e Processos de Interferência, Degradação e Dano Ambiental. In: Cunha, Sandra Baptista da; Guerra, Antonio José Teixeira (Orgs.). Avaliação e Perícia Ambiental. Bertrand Brasil, Rio de Janeiro, 2002. pp. 18-75.

BASTOS, Ana Christina Saramago; ALMEIDA, Josimar Ribeiro de. Licenciamento Ambiental Brasileiro no Contexto da Avaliação de Impactos Ambientais. In: Cunha, Sandra Baptista da; Guerra, Antonio José Teixeira (Orgs.). Avaliação e Perícia Ambiental. Bertrand Brasil, Rio de Janeiro, 2002. pp. 77-110.

BERTRAND, G. Paisagem e Geografia Física Global - espaço Metodológico. Trad. Olga cruz. São Paulo, IGEO/USP, Série Cadernos de Ciências da Terra, 13:1-27, 1971.

BULLOCK, D.; QUIROGA, C.; SCHWEHN, C. Travel Time Collection in Urban Areas. Lousiana State University Press, New Orleans, 1998.

CARLOS, Ana Fani Alessandri. Dissertação de Mestrado apresentada ao Programa de Pós Graduação em Geografia Humana da FFLCH/USP. Reflexões sobre o Espaço Geográfico, São Paulo, 1979.

CAVALCANTI, Clóvis. Revista Iberoamericana de Economia Ecológica. Vol. 1: 110. Economia e Ecologia: Problemas da Governança Ambiental no Brasil. Instituto de Pesquisas Sociais da Fundação Joaquim Nabuco. Recife, 2004.

CETESB. Companhia de Tecnologia de Saneamento Ambiental. Inventário Estadual de Resíduos Sólidos Domiciliares - Relatório de 2007. São Paulo, 2008. 
CETESB. Companhia de Tecnologia de Saneamento Ambiental. Relatório de Qualidade do Ar no Estado de São Paulo - Relatório de 2006. São Paulo, 2007.

CHRISTOFOLETTI, A. A Análise de Bacias Hidrográficas. In: Geomorfologia. São Paulo: Edgard Blüncher, 1976 (p.81-97).

CONTI, J.B. Geografia e Climatologia, Revista GEOUSP, № 09, São Paulo, 2001. CORBUCCl, Eliana Maria. Políticas Públicas, Políticas Ambientais e Participação Social no Brasil. Espaço \& Geografia, Vol.6, No 2, 59:87. ISSN: 15169375. 2003.

CORREAA. Roberto Lobato. Trajetórias Geográficas. Rio de Janeiro. Bertrand Brasil, 1997.

CREA. Conselho Regional de Engenharia e Arquitetura. Atribuições Legais do Geógrafo. Disponível em: www.creasp.org.br . Acesso em 16.04.2008.

DG. Departamento de Geografia. Plano de Metas Acadêmicas: Período de 20042008. Faculdade de Filosofia, Letras e Ciências Humanas da Universidade de São Paulo. São Paulo, 2003.

DELPOUX, M. Ecossistema e Paisagem. São Paulo: FFLCH - Instituto de Geografia, 1974.

FAUCHER, Daniel. De los Paises a Las Regiones. In: El Pensamiento Geográfico. Josefina Gómez Mendoza, Julio Muñoz Jiménez y Nicolas Ortega Cantero. Alianza Editorial. Madrid. 1982.

GARRISON, William L. Studies of Highway Development and Geographic Change. University of Washington Press, Seattle, 1959.

GHIRALDELLI Júnior, Paulo. O que é ser crítico - na filosofia e na educação. Disponível em http://br.groups.yahoo.com/group/listageografia/message/52517

Acesso em 02.08.2009.

GONÇALVES, Luís. A crítica como prolegómeno de construção. Disponível em: http://valverdecity.forumotion.com/para-comecar-f1/a-critica-como-prolegomeno-deconstrucao-t19.htm . Acesso em 04.08.2009. 
GRIGG, David. Regiões, Modelos e Classes. In: Modelos Integrados em Geografia. Chorley, RJ e Hagget, P. Rio de Janeiro. Livros Técnicos e Científicos, S.A/EDUSP. 1974.

HURST, Michael E. Eliot. Transportation Geography. Comments and Readings. Mcgraw Hills Books Company: New York, 1974.

INMET. Instituto Nacional de Meteorologia. Precipitação Média no Município de São Paulo, período de "Normais Climatológicas" - 1961 a 1990. 2007.

KLINK, H.J. Geoecologia e Regionalização Natural. Bases para Pesquisa Ambiental. São Paulo: FFLCH - Instituto de Geografia, 1981.

LENCIONI, Sandra. Região e Geografia. A Noção de região no pensamento geográfico. In: Novos Caminhos da Geografia. Ana Fani Alessandri Carlos (org.). São Paulo. Contexto. 1999.

LOPES, Luciana. Dissertação de Mestrado apresentada ao Programa de Pós Graduação em Geografia Humana da FFLCH/USP. Gestão e Gerenciamento Integrados dos Resíduos Sólidos Urbanos - Alternativas para Pequenos Municípios, São Paulo, 2006.

MEDEIROS, R.M.V. A Relevância dos Aspectos Sociais nos Estudos de Impacto Ambiental. In: RIMA Relatório de Impacto Ambiental: Legislação, elaboração e resultados. Verdum, Roberto; Medeiros, Rosa Maria Vieira (Orgs.). Editora da Universidade do Rio Grande do Sul, Rio Grande do Sul, 2002.

METZGER, Jean Paul. O que é Ecologia de Paisagens. São Paulo. LEPAC Laboratório de Ecologia de Paisagens e Conservação, Instituto de Biociências USP, 2001.

MONBEIG, Pierre. Papel e Valor do Ensino da Geografia e de sua Pesquisa. Boletim Carioca de Geografia (AGB), Ano VII, Volume I e II, 1954

MORAES, Antonio Carlos Robert. Contribuições para a Gestão da Zona Costeira do Brasil. Elementos para uma Geografia do Litoral Brasileiro. São Paulo. HUCITEC, EDUSP, 1999. 
MOREIRA, Ruy. Da Região à Rede e ao Lugar. In: Bauru: AGB - Revista Ciência Geográfica, n. 06, 1997.

NAGEL, Ernest. Ciência: Natureza e Objetivo. In: Sidney MORGENBESSER. Filosofia das ciências. São Paulo: Cultrix, 1971.

PEDROSO, Nelson Garcia (org.). Geógrafos: Legislação, Formação e Mercado de Trabalho. São Paulo. Associação dos Geógrafos Brasileiros, 1996.

PMSP. Prefeitura do Município de São Paulo. Atlas Ambiental do Município de São Paulo. São Paulo, 2004.

RODRIGUES, J.R. Roteiro para Apresentação de Estudos de Impacto Ambiental. In: RIMA Relatório de Impacto Ambiental: Legislação, elaboração e resultados. Verdum, Roberto; Medeiros, Rosa Maria Vieira (Orgs.). Editora da Universidade do Rio Grande do Sul, Rio Grande do Sul, 2002.

ROSS, Jurandyr Luciano Sanches. Geomorfologia, Ambiente e Planejamento. Contexto, São Paulo 1990.

ROSS, Jurandyr Luciano Sanches. Ecogeografia do Brasil: Subsídios para Planejamento Ambiental. Oficina de Textos. São Paulo, 2006.

SÁNCHEZ, Luis Enrique. Avaliação de Impacto Ambiental: conceitos e métodos. Oficina de Textos. São Paulo, 2008.

SANTOS, Milton. A Natureza do Espaço. Técnica e Tempo. Razão e Emoção. Editora da Universidade de São Paulo. São Paulo, 2002.

Paulo. 1978.

O Trabalho do Geógrafo no Terceiro Mundo. HUCITEC. São

SANTOS, Rosely Ferreira dos. Planejamento Ambiental: Teoria e Prática. Oficina de Textos. São Paulo, 2004.

SAUER, C.D. The morphology of landscape. Publication in Geography. University of California, 1925,v.2,n.2, pp. $19-54$. 
SILVA, Armando Corrêa da. As Categorias Como Fundamento do Conhecimento Geográfico. In: O Espaço Interdisciplinar. Milton Santos, Maria Adélia (coord.). São Paulo. Nobel, 1986.

SILVA, Pedro Paulo de Lima; GUERRA, Antonio José Teixeira; DUTRA, Luiz Eduardo Duque. Subsídios para Avaliação Econômica de Impactos Ambientais. In: Cunha, Sandra Baptista da; Guerra, Antonio José Teixeira (Orgs.). Avaliação e Perícia Ambiental. Bertrand Brasil, Rio de Janeiro, 2002. pp. 217-259.

SMA. Secretaria de Meio Ambiente. Licenciamento Ambiental. Disponível em http://www.cetesb.sp.gov.br/licenciamentoo/onde_fazer/define_licenciamento.asp Acesso em 22.02.2007.

SOTCHAVA, V. B. Por uma Teoria de Classificação de Geossistemas de Vida Terrestre. São Paulo: FFLCH - Instituto de Geografia, 1978.

STORPER, M. A Industrialização e a Questão Regional. In: Reestruturação Urbana. Valadares, L. Preteceille. (Coord.). Nobel/IUPERJ, São Paulo, 1990.

TRICART, J. Ecodinâmica. IBGE, SUPREN, Rio de Janeiro, 1977.

THRIFT, Nigel. Visando o Âmago da Região. In: Geografia Humana: Sociedade, Espaço e Ciência Social. Derek Gregory, Ron Martin, Graham Smith (orgs.). Rio de Janeiro. Jorge Zahar, 1996.

UNESP, Universidade Estadual Paulista. Apostila de Normalização Documentária (Com Base nas Normas ABNT). Presidente Prudente, 2006.

VENTURI, Luis Antonio Bittar. Ensaios Geográficos. São Paulo. Humanitas, 2008.

VERDUM, Roberto. Revista do Departamento de Geografia, Os Geógrafos Frente às Dinâmicas Sócio-Ambientais No Brasil, nº 16, 2005, pp. 91-94.

VERDUM, Roberto; MEDEIROS, Rosa Maria Vieira (Orgs.). RIMA Relatório de Impacto Ambiental: Legislação, elaboração e resultados. Editora da Universidade do Rio Grande do Sul, Rio Grande do Sul, 2002. 
ANEXO A - Questionário 01: Para profissionais com formações diversas. Nome (opcional):

Formação e Instituição de Ensino:

1) Você, como atuante na área de estudos de impacto ambiental, de quantos projetos aproximadamente já participou?

2) Deste total, em quantos aproximadamente havia geógrafos na equipe técnica?

3) Qual o nível de qualidade você considera haver num relatório elaborado por um geógrafo?

4) Como você vê a atuação de geógrafos neste campo profissional?

5) Quais relatórios e demais contribuições você acredita que um geógrafo poderia oferecer a um EIA?

6) Se você estivesse formando a equipe técnica multidisciplinar, você convidaria um geógrafo? Justifique a resposta.

7) Quais profissionais você julga imprescindiveis na equipe técnica multidisciplinar que elaboraria um EIA?

8) Quais profissionais você considera pouco importantes na formação desta equipe? 
ANEXO B - Questionário 02: Para geógrafos.

Nome (opcional):

Ano de Formação e Instituição de Ensino:

1) Você, como atuante na área de estudos de impacto ambiental, de quantos projetos aproximadamente já participou?

2) Deste total, em quantos aproximadamente havia geógrafos na equipe técnica, além de você?

3) Como você vê a atuação de geógrafos neste campo profissional?

4) Quais relatórios e demais contribuições você acredita que um geógrafo pode oferecer a um EIA?

5) Se você estivesse formando a equipe técnica multidisciplinar, você convidaria um geógrafo? Justifique a resposta.

6) Quais profissionais você julga imprescindiveis na equipe técnica multidisciplinar que elaboraria um EIA?

7) Quais profissionais você considera pouco importantes na formação desta equipe?

8) Com sua experiência, em termos percentuais, qual a participação dos geógrafos em EIAs. Ou seja, em 100 EIAs, em quantos deles, acredita haver um geógrafo?

10) Você acredita estar bem amparado pelo CREA?

11) Você acredita que a formação da geografia, Ihe permite atuar com propriedade neste ramo profissional? 